
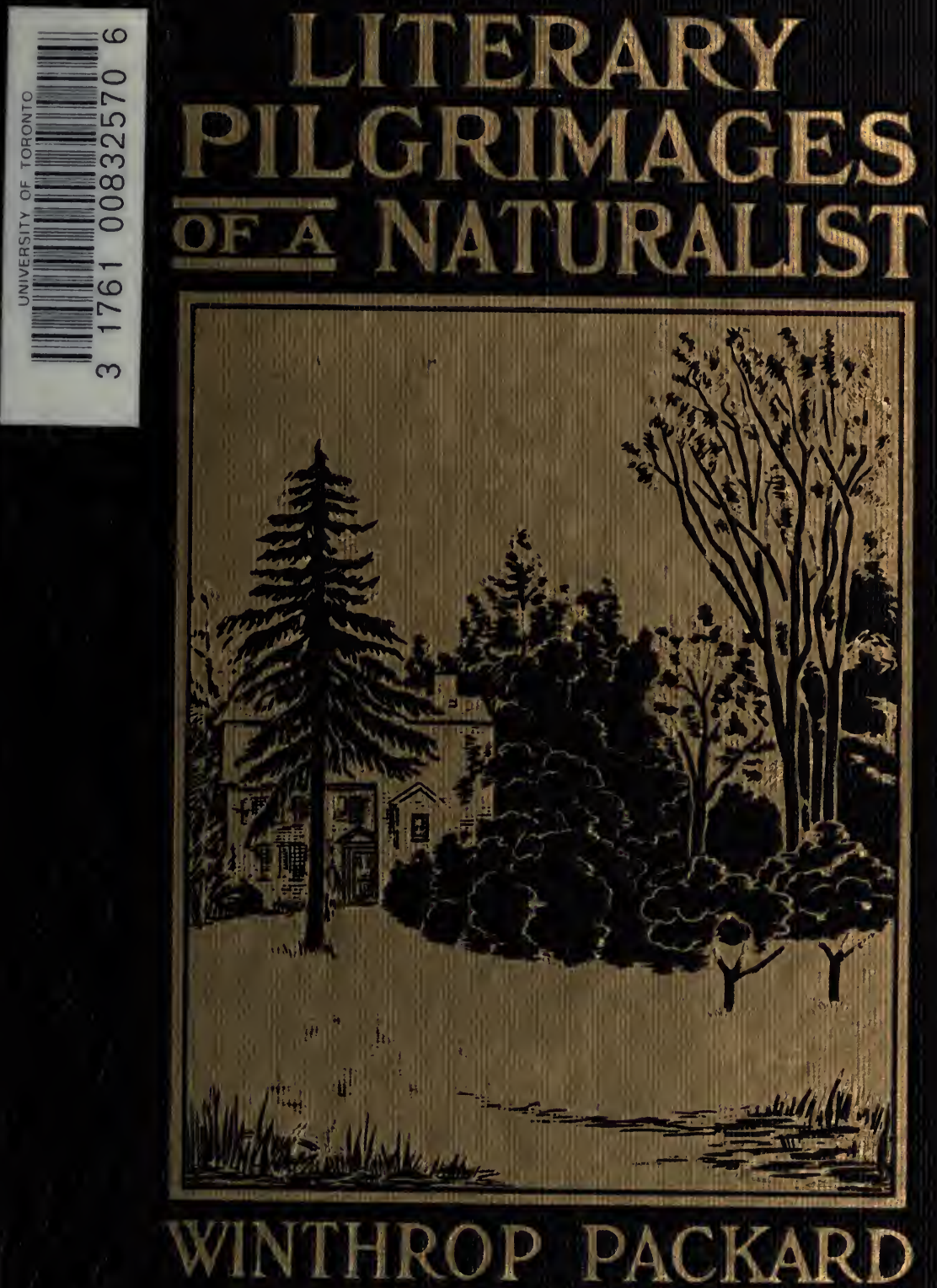


$$
\frac{Q H}{P I R}
$$


Hresented ta

Hirtariat Uallege

from the library af the late

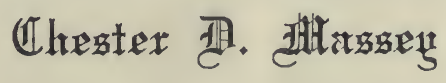





\section{LITERARY PILGRIMAGES OF A NATURALIST}




\section{THE WORKS OF \\ W I N THROP PACKARD \\ WOODLAND PATHS \\ WILD PASTURES \\ WOOD WANDERINGS \\ WILDWOOD WAYS}

Each illustrated by Charles Copeland

12mo. Ornamental cloth, gilt top, each volume \$1.20 net; by mail, $\$ 1.28$

These four volumes together constitute "The New England Year" series, dealing, in the order given, with the four

seasons. Sold separately.

\section{FLORIDA TRAILS}

As seen from Jacksonville to Key West, and from

November to April, inclusive

Illustrated from photographs by the author and others

8 vo. Ornamental cloth, gilt top, boxed, $\$ 3.00$ net; by mail, $\$ 3.25$

\section{LITERARY PILGRIMAGES OF}

A NATURALIST

Visits to the haunts of Whittier, Emerson, Hawthorne,

Celia Thaxter, Webster, Aldrich, and others

Illustrated from photographs by the author and others

$12 \mathrm{mo}$. Ornamental cloth, gilt top, boxed, $\$ 2.00$ net; by mail, $\$ 2.20$

\section{SMALL, MAYNARD AND COMPANY}


Digitized by the Internet Archive in 2008 with funding from Microsoft Corporation 


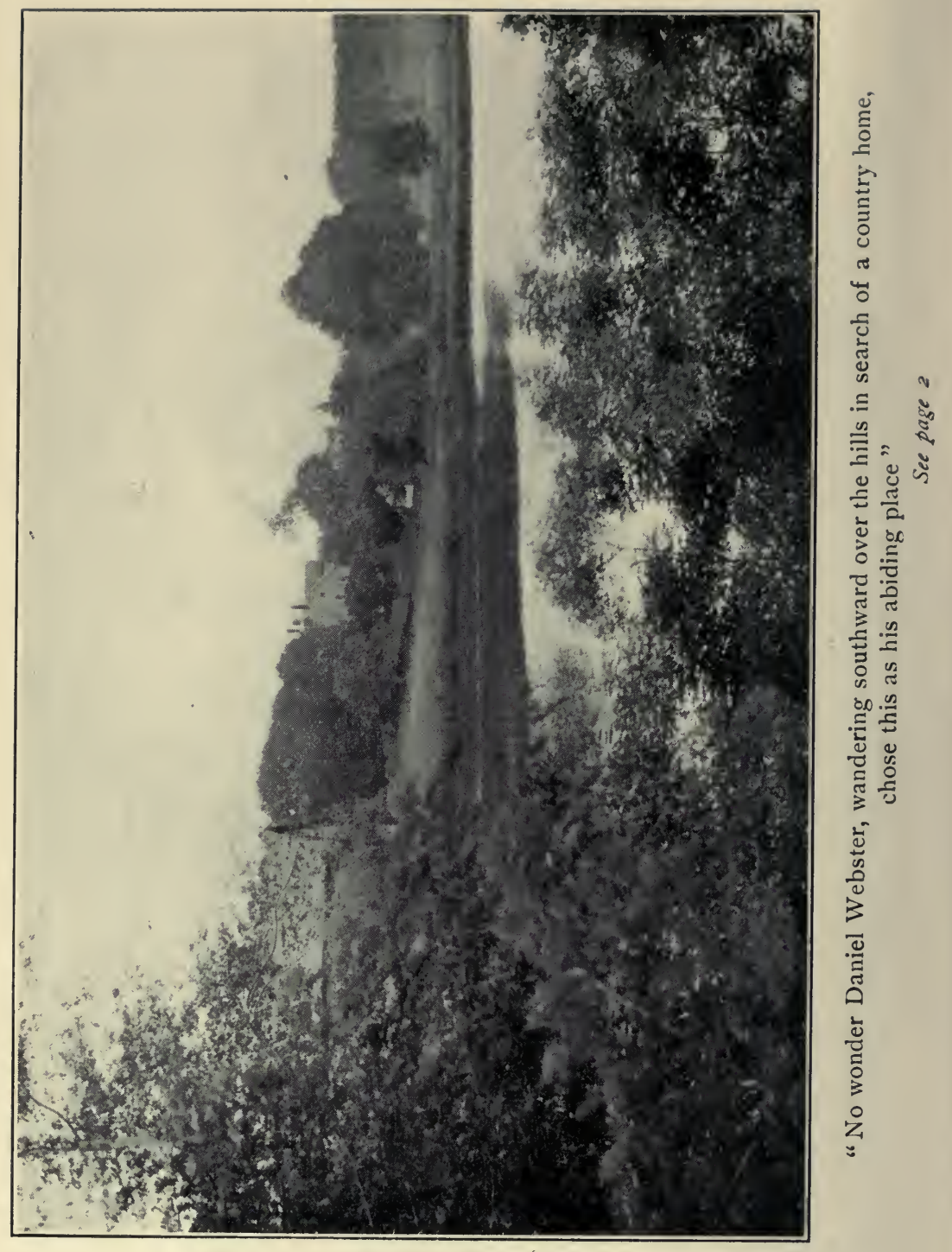




\title{
LITERARY PILGRIMAGES
}

\author{
OF \\ A NATURALIST
}

\author{
BY \\ WINTHROP PACKARD \\ Autbor of "Florida Trails," "Wild Pastures," \\ "Wood Wanderings," etc. \\ ILLUSTRATED FROM PHOTOGRAPHS BY THE \\ AUTHOR AND OTHERS
}

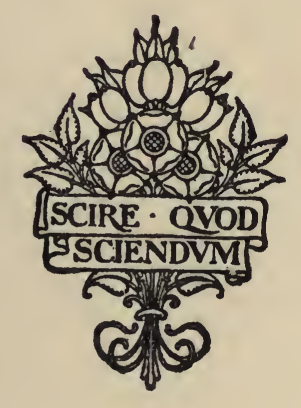

BOSTON

SMALL, MAYNARD AND COMPANY

PUBLISHERS 


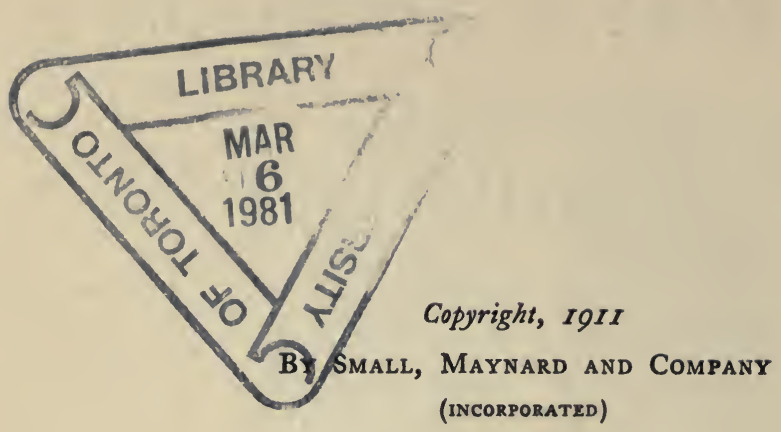

Entered at Stationers' Hall

PH

$\begin{array}{ll}8 & 39019 \\ P_{3} & 19-10-1926\end{array}$

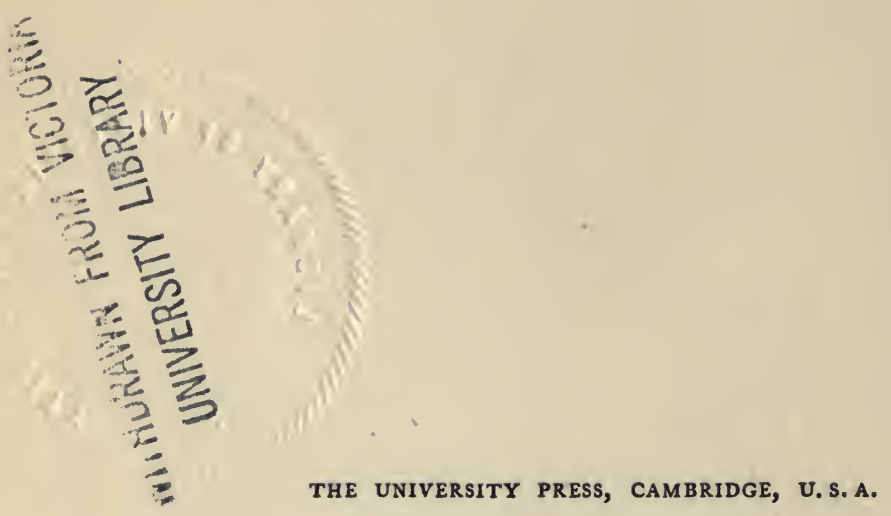


TO THE MEMORY

OF

CLARENCE H. BERRY

A Schoolmaster of Long Ago

THIS BOOK IS AFFECTIONATELY DEDICATED 

THE author wishes to express his thanks to the editors of the "Boston Evening Transcript" for permission to reprint in this volume matter which was originally contributed to its columns. 



\section{CONTENTS}

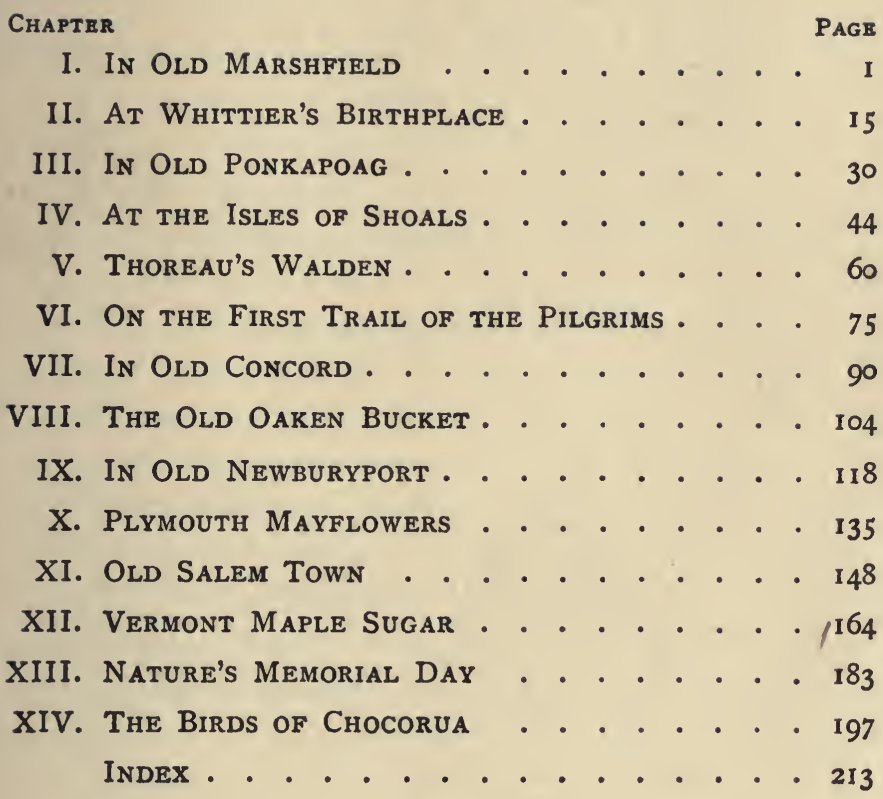





\section{ILLUSTRATIONS}

PAGE

"No wonder Daniel Webster, wandering southward over the hills in search of a country home, chose this as his abiding-place." See page 2 . . . . . Frontispiece

"Telling the pearls on this rosary of a path one is led beyond the homestead" . . . . . . . . . . . I2

"Within this wide circle, with the house its core, and the hearth its shrine, revolved the homely, cheerful, wholehearted life of the farm" . . . . . . . . . 22

"Watching the crane and pendant trammels grow black against the blaze." See page 18 . . . . . . 28

A corner of the room in which Whittier was born . . . 28

"The study where Aldrich wrote some of his daintiest verse looks forth upon a sweet valley" . . . . . . 30

"The study window in what was "The Bemis Place' of the elder days of Ponkapoag." See page 35 . . . . . . 36

Celia Thaxter's home at the Isles of Shoals . . . . . 44

"Chasms down which you may walk to the tide between sheer cliffs" . . . . . . . . . . . . 50

"Up to the smooth turf on this knoll crowd all the pasture shrubs that she loved". . . . . . . . . 58

"Here is the cairn erected to his memory, to which with doffed hat you may well add a stone." See page 65 . . 66

"Walden is Walden still, very much as Thoreau painted it" 70

"Pilgrim Lake," where that first washing was done by the Pilgrim mothers . . . . . . . . . . 78 
"That little creek that blocked the way of doughty Myles Standish and his men, sending them inland on a detour." See page 85. . . . . . . . . . . .

"Here in a volley was the summing-up of the nature of the heroes that had grown up, quite literally, in the Concord soil." See page 93 . . . . . . . . . . . . . 92

"Hither, too, came Hawthorne, to tramp the woods as did the others, and feel as did they, the divine afflatus" . . 98

"The water from the old well cooled the throat of his memory, and sparkled to the eye of it as he recalled the dripping bucket". . . . . . . . . . . . II

The Newburyport home of Joshua Coffin, the early friend and teacher of Whittier . . . . . . . I 26

"Down river to the old chain bridge the rough rocks of the New Hampshire hills come to get a taste of salt." See page 129. . . . . . . . . . . . . . . . . 130

One angle of "The House of the Seven Gables" . . . . 150

"A Salem dock of the old sea-faring days" . . . . . . I50

"The only sound was the crunch of soft snow and the splash of sap within the barrel." See page 171 . . . . . . 172

"But here is a sweetness that the tree almost bursts to deliver". . . . . . . . . . . . . 178

"The farmhouse where Bolles lived and loved the woods and all that therein lived with him." See page 197 . . . . 198 Nightfall on Chocorua Lake . . . . . . . . 208 


\section{LITERARY PILGRIMAGES}

OF A NATURALIST 



\title{
LITERARY PILGRIMAGES OF A NATURALIST
}

\author{
I \\ IN OLD MARSHFIELD \\ Glimpses of the Country about the \\ Daniel Webster Place
}

Down in Marshfield early morning brings to the roadside troops of blue-eyed chicory blooms, shy memories of fair Pilgrim children who once trod these ways. They do not stay long with the wanderer, these early morning blooms. The turmoil and heat of the mid-summer day close them, but the dreams they bring ramble with the roads in happy freedom from all care among drumlins and kames, vanishing in the flooding heat of some wood-enclosed pasture corner to spring laughingly back again as the way tops a hill and gives a glimpse of the purple velvet of the sea. No wonder Peregrine White, the first fairskinned child born in New England, strayed from 
the boundaries of Plymouth and chose his home here. No wonder Daniel Webster, New England's most vivid great man, wandering southward over the hills in search of a country home two centuries later, fixed upon the spot just below Black Mount, looking down upon Green Harbor marshes and the sea, and chose this for his abiding-place.

The statesman and orator, whose words still ring across the years to us, with the trumpet sounding in them even from the printed page, may well have breathed inspiration for them from the winds that come from seaward across the aromatic marshes. There is cool truthfulness in these winds, and understanding of the depths, and the salty, wild flavor of the untamed marsh gives them a tang of primal vitality. Breasting them at mid-day from under the wilt of summer heat you seem to drink air rather than to breathe it, and find intoxication in the draught. I never heard a robin sing in mid-flight, soaring upward like a skylark, till I came to this bit of sweet New England country. The east wind drifted in to him as he sat on a treetop caroling, and he spread his 
wings to it and fluttered upward, pouring out round notes of melody as he went. Webster's most famous speeches were composed while he tramped these hills and marshes and sailed the blue velvet of the outlying sea, and their richest phrases soar as they sing, even as did the robin.

You may come to Black Mount with its panoramic view of the Webster farm, the surrounding pastures and marshes and the little Pilgrim cemetery where he lies buried, from either the Marshfield railway station or that of Green Harbor, both a mile or more away by road. A better route lay for me through the woods by paths flecked with sunlight and dappled with shadow, paths which the Pilgrims' descendants first sought out and which are as fair to-day to our feet as they were to theirs. One can easily fancy Peregrine and his wife picking berries along here on days when the farm work allowed them freedom, the children frolicking about with them and eating or spilling half they picked, as the children do on these hills now. Voices and laughter rang through the woods as I passed, and there is small blame to the pickers if they do eat the berries as 
fast as they pick them. They never taste quite so good as on this direct route from producer to consumer. Along this path you may have your choice of varieties as you go, from the pale blue ones that grow so very near the earth on their tiny bushes that they seem the salt of it, giving the day its zest, through the low-bush-blacks, crisp with seeds and aromatic in flavor as if smoked with the incense of the sweet fern, to those other black ones that grow on the high bushes and rightfully take the name of huckleberry. The soil of these sandy hills may be thin and not worth farming, but it produces fruit whose quality puts to shame the product of wellcultivated gardens. The good bishop of England who once said, "Doubtless God could have produced a better berry than the strawberry, but doubtless He never did," never ate blueberries from the bush in a New England pasture.

From the summit of Black Mount the grassy hill slopes sharply beneath your feet to the road and beyond this to the home acres of the Webster place, the roof tree far below you and the house snuggling among the trees that the great states- 
man loved, many of which he planted. A little farther on stands a great barn with huge mows and the big hay doors front and rear always hospitably open to the scores of barn swallows that build on the beams up next the roof. In no barn have I found quite so many swallows at home. At every vantage point on a beam, wherever a corner of a timber or a locking pin protrudes to give a support, nests have been built, generation following generation till some of the structures are curious, deep, inverted mud pyramids, topped with straw and grass and lined with feathers, downy beds for the clamorous young. I can think of no finer picture of rural peace than such a barn as this, the cool wind sighing gently through the wide doors, the beams stretching across the cavernous space above dotted with the gray nests, the air full of the friendly, homey twittering of the birds, some resting and preening their feathers on the beams, others swinging in amazing flight down and out through the doors to skim the grass of the neighboring fields and marshes for food, then flashing back again to the hungry nestlings. Such barns grow fewer year by year here in 
eastern Massachusetts, and the pleasant intimacy of the barn swallows is but a happy recollection in the mind of many of us, more is the pity. It is worth a trip to Marshfield just to foregather with such a colony.

Eastward again the eye passes over wide mowing fields, rough pastures and hills clad with short, brown grass and red cedars, the thousand-tree orchard of Baldwin apples which Webster planted, the tiny Pilgrim cemetery on a little hillock where he lies buried among the pioneers of the place, the brown-green marshes flecked with the silver of the full tide, to the deep, velvety blue rim of the sea, which sweeps in its splendid curve uninterrupted from north to south. Behind your back is the rich green of Massachusetts woodland, beneath your feet this landscape of pasture, field and marsh, scarcely changed since Webster's day, changed but little indeed since the days of Peregrine White and his pioneer neighbors, and rimming it round the deep sapphire romance of the sea. Across this blue romance of sea the winds of the world, fresh and vital with brine, come to woo you on your way. They croon in your ears 
the strange sagas that the blood of no wanderer can resist, and you know something of the lure that led the vikings of old ever onward to new shores as you plunge down the grassy slope to meet them. The stately beauty of the home place may thrall you for a while beneath the trees and the friendly great barn try to lull you to contentment with the cradle songs of the swallows, but the marsh adds its wild, free tang to the muted trumpets which these east winds blow in your ears, and so you fare onward through a country of enchantment, toward the ocean.

Webster's well house, where still the ancient spring flows, cool and clear, gave me a drink as I went by. The dyke which borders his cranberry bog and separates it from a tiny pond where white pond lilies floated and perfumed the air, gave further progress eastward, and soon I passed naturally into an old, old path which led me purposefully in the desired direction. Without looking for it I had found the footpath way which rambles from the farm across country to Green Harbor, where the statesman kept his boats, a path without doubt often trodden by his feet in 
seaward excursions. He could have found no pleasanter way. The pastures which lie between upland and marsh in this region are covered with a wild, free growth of shrub and vine which no herds, however ravenous, can keep down. The best that the cattle can do with them is to beat paths through the lush tangle along which wild grasses find room to work upward toward the light and add to the browse. Here the greenbrier grows greener and more briery than anywhere else that I know, and the stag-horn sumac emulates it in vigor of growth if not in convolutions. In places these reach almost the dignity of young trees, and the pinnate leaves spread a wide, fernlike shade as I walked beneath the antler-like branches. The stag-horn sumac is surely rightly named. Its antlers are covered now with an exquisite, deep, soft velvet which clothes them to the leafbud tips and along the very petioles of the leaves. Now it is a clear green which with later growth will become purple and pass into brown, the promise of autumn showing now in a slight purple tinge on the sun-ripened petioles of the older leaves. This soft fuzz clothes the 
crowded, conical heads of bloom also, heads that are of the same sweet pink as the petals of the wild roses which grow near by as you may see if you will hold one up against the other. But the pink of the wild rose seems flat against that of the sumac, for it has only a smooth surface on which to show itself, while that of the sumac is full of soft, shadowy withdrawals and shows a yellow background in the interstices of the blossom spike.

Skirting this jungle so aromatic with scent of sassafras and bayberry, perfumed with wild rose and azalea, pulsing with the flight of unseen birds in its cool depth and echoing with their song, the path crosses a brook that gently chuckles to itself over its escape from the monotony of a big mowing field to the salt freedom of the marsh, then suddenly breasts the steep northern side of a drumlin. Here the press of toiling feet has been supplemented by the wash of torrential rains till the narrow way becomes a miniature chasm in places, worn down in the gravel among great red cedars, hoary with age and lichens. To know the slow growth of a red cedar and to calculate the 
age of these by dividing their present bulk with the slight increase that each year brings is to place the birth of these trees far back in the centuries. Not one hundred years will account for it, nor two, and I am quite sure that these trees were growing where they now stand when Peregrine White's mother first embarked on the Mayflower at Southampton. Webster's path may have gone through them then, and no one knows how long before, for it is worn deep not only on the steep hillsides where the rains have helped it but in level reaches beyond where only the passing and repassing of feet through centuries would have done it. It was as direct a route from the hills to the mouth of Cut River at Green Harbor before the white man's time as after, and if I am not mistaken the red men trod it long before the first ship's keel furrowed Plymouth Bay.

As I topped the rise I found myself in a hilltop pasture a half-mile long which covers the rest of the hill. Once it was a cultivated field, and the corn-hills of the last planter still show in spots, these, like the rest of it, now overgrown with close-set grass and crisp reindeer lichen. The 
patriarchal cedars I had left behind, old men of their tribe sitting solemn and motionless in council. Here I had come upon a vast but scattered concourse of young people, lithe and slender folk who seemed to stroll gayly all about the place. Here were plumed youths and debonair maidens regarding one another, family groups, mothers with children at the knee and other little folk in the very attitude of playing romping games. But there were tinier folk than these, too small to be real cedars, gamboling among the others, as if underworld sprites also in cedar guise had come forth to join the festivities. Nowhere else have I seen such a merry concourse of cedars as on the long top of this hill that some Pilgrim father first cleared for a cornfield two centuries and a half ago. Here and there little groups of wee wild rose shrubs seemed to dance up and scatter. perfume about their feet in tribute, then stand motionless like diffident children, finger in mouth, stolid and uncommunicative. Hilltops are often lonely, but this one could never be. It gladdens with its quaint fancies. Through a veritable picnic of young cedars I tramped down the east- 
ward slope to the dusty road that leads on to Green Harbor and the slumbrous uproar of the surf.

Telling the pearls on this rosary of a path in the homeward direction one is led beyond the homestead and on, by a slenderer, less trodden way to the old Pilgrim cemetery where the great man lies buried among the pioneers of the neighborhood, Peregrine White, the Winslows, and a host of others whose fame has not gone so far perhaps, but those names may be written in the final domesday book in letters as large as his. Nor does any storied monument recite the deeds of the statesman or bear his name higher than that of his fellows. A simple slab with the name only stands above the mound beneath which he lies, and in the side of this mound a woodchuck has his burrow, seeming to emphasize by his presence the cosy friendliness of the little spot. It is a hillock, just a little way from the house, just a little way from the big orchard which Webster loved so well, surrounded by pasture and cranberry bog and with the marsh drawing lovingly up to it on one side. Over this marsh comes 


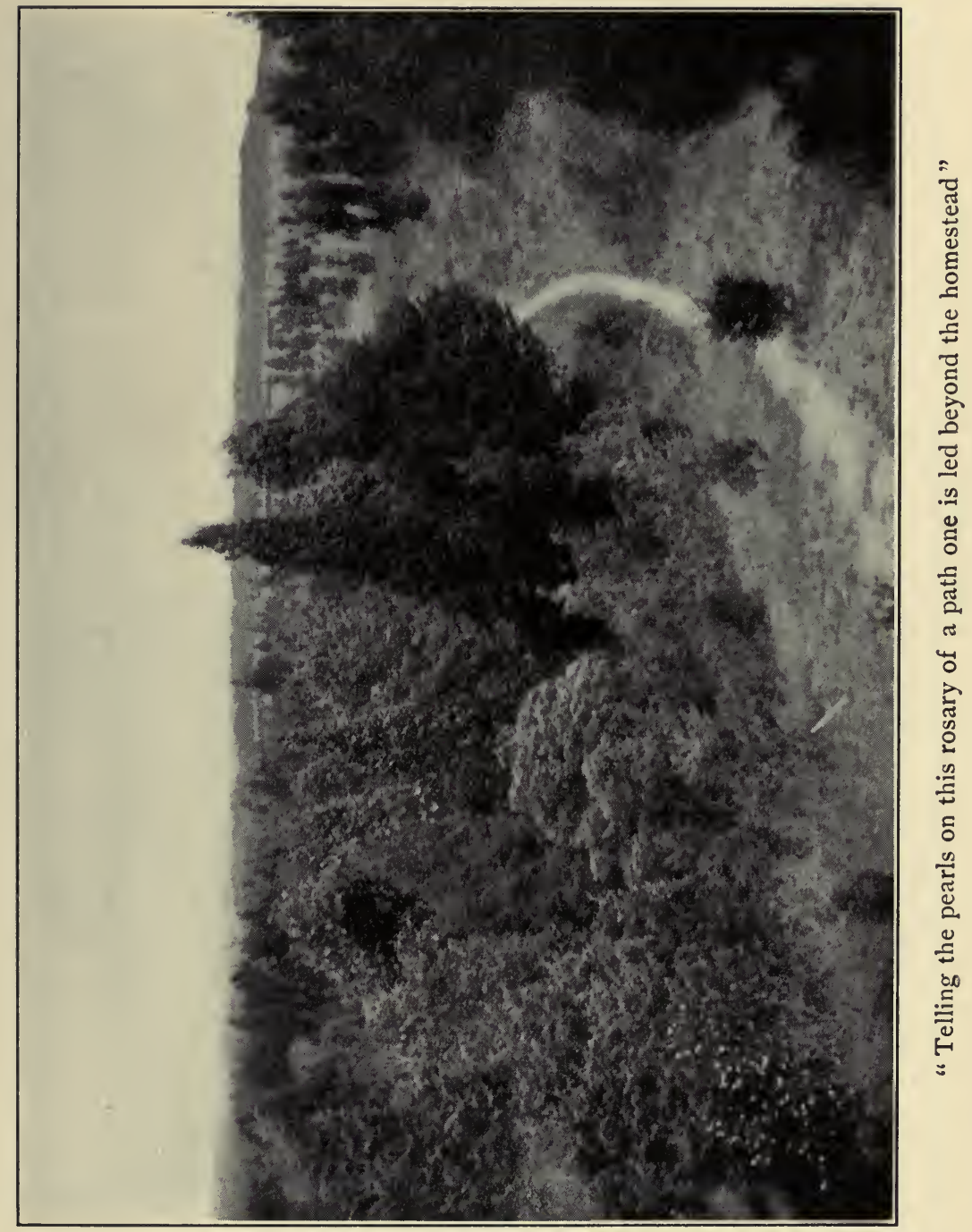


a. 
the free salt air of the sea, but a little more gently to the lowly hillock than to the summit of Black Mount. Because of this loitering gentleness it has time to drop among the lingerers there all the wild aromas and soft perfumes of the marsh and pasture and bring all the soothing sounds of life to ears that for all I know hear them dreamily and approve. Quail, the first I have heard in New England for a long time, whistled cheerily one to another from nearby thickets. Nor did these seem fearful of man. One whistled as a wagon rattled by his hiding place on the dusty winding road, and held his perch beneath a berry bush till I approached so near that I could hear the full inflection of the soft note with which he prefixed his " bob white," see the swell of his white throat and the tilt of his head as he sent forth the call. A pair of mourning doves crooned in the old apple orchard and flew on whistling wings as I approached too near. I have heard heartache in the tones of these birds, but here their mourning seemed only the gentle sorrow of a mother's tones as she sonthes a weary child, a mourning that voiced love and sympathy rather than pain. On 
a tree nearby a great-crested flycatcher sat and seemed to say to himself, "grief, grief," These were the only notes of sorrow that the place held. All else in sky and field, marsh and hillside, seemed to thrill with a gentle optimism, and the hillock itself rested amidst this in a patriarchal peace and simplicity that became it well. Memory of this gentle peace and simplicity lingers long and runs like a tender refrain through the harmony of fragrant, vivid life that marks this lovely section of old Marshfield. 


\section{AT WHITTIER'S BIRTHPLACE}

The Homestead two Centuries Old and the Unspoiled Country about it

They lighted a fire for me in Whittier's fireplace. The day had been one of wilting July heat and sun glare till storm clouds from the New Hampshire hills brought sudden cool winds and black shadows. Twilight settled down in the wide, ancient living-room, bringing brooding darkness and mystery. The little light that came through the tiny, lilac-shaded windows seemed to half reveal ghosts of legends and romance, wrapped in darkness, slipping indistinctly from the black cavern of the fireplace, standing close before it and hiding it, and gathering in formless groups in the corners of the room. They whispered and the leaves on the trees outside rustled the tale, while echoes of warlock warfare rumbled in the sky above and witch fires flared. A witches' twilight had come down the Merrimac and 
brought under its blanket shades of all the mountain legends that had in times past trooped to the mind of the poet as he sat there with sensitive soul a-quiver to their touch, photographing them in black and white for the minds of all men forever. From the fireplace stalked Mogg Megone and the powwows of his tribe, bringing with them all the dusky people of the weird stories of his day. The wind wailed their lone songs outside, and in its deep throat the aged chimney mumbled to itself old, old tales of night and darkness.

Then a slender flame slipped upward from the hearth, showing the form of the caretaker faintly shadowed and edged with light against the black background, and if I saw not her but the outline of Whittier's mother bending to light the fire and drive from the minds of the children the fancies of the dusk it must have been because the witches' twilight still held the room under its spell. Between the fore and back logs the brush of hemlock and of pine crackled and sent incense across the gloom to me, and with the leap of the flame all the weird shadows wavered into the corner and vanished. In their stead trooped up river the 
cheery hearthside stories of the English settlers, sturdy tales and rough perhaps but with the glow of the hearth log flickering gleefully through them. The gusts drew whirling sparks upward, and in its deep throat the chimney, no longer aged but stout and strong with vigorous work to do, guffawed in cheerful content. The dancing firelight sent gleams of quiet laughter over the face of Whittier himself, that before had looked so grimly from the frame over his ancient desk, and the room glowed with homey hospitality. If there were shades there they were golden ones of gentle maids and rollicking boys that we knew and loved so well, and though without the window opposite the fireplace and right through the shading lilac bushes a ghostly replica of the fireplace with its flickering flames appeared and vanished and reappeared, there was nothing sinister in its uncanniness, for

$$
\text { " under the tree }
$$

When fire outside burns merrily, There the witches are making tea."

Stormbound if not snowbound I sat for an hour by the hearth that was the heart of a home for 
two hundred years, watching the crane and pendent trammels show black against the blaze, seeing the Turk's heads on the andirons glow, reading by the firelight verses which the poet wrote in that same home room, and when the storm passed and I could go forth to his brook and his fields and hills it could not fail to be with something of his love for them in my heart. Some critic, whose visit must have been shortened by homesick memories of a steam-heated flat, has said that Whittier's birthplace is lonely and that its loneliness had its effect on his life and work. But how could such a place be lonely to a man who was born there? Here was the great living-room with its hearth, where the life of the home centered. Without was the wonderful rolling country with all its majesty of hill, whence he saw the crystal mountains to north and the blue lure of the sea to eastward, with all its gentle delights of ravines where brooks laughed, and meadows and swamps where they slipped peacefully along, mirroring the sky, watering all wild flowers and offering refuge to all wild creatures. Within this wide circle, with the house its core and the hearth its shrine, 
revolved the homely, cheerful, whole-hearted life of the farm. What chance for loneliness was there?

After the shower had passed I climbed the gentle slope of the hill back of the house, traversing the old garden where grow the plants that came over with pioneers from England, hollyhocks and sweet william, old-time poppies, marjoram and London pride, dear to every housewife's heart in the good old days when to wrest a farm from the forest and build a home on it was still an ambition for which a free-born New Englander need feel no shame. The witchery of the hour had not been for the hearth-side alone. The sooth of the rain had been for the hearts of these also, and the joy of their answering delight made all the fresh air sweet and kindly so far as the gentle winds blew. The perfume of an old-time garden after rain is made up of gracious memories. Wherever chance has taken their seeds or care has transported their roots a thousand generations of sweet-hearted, home-keeping mothers have tended these plants and loved their flowers and the very leaves and stalks on which 
they grew. The caress of the rain brings from each leaf and petal but the aromatic essence of such lives, welling within and flowing forth again through the unnumbered years.

Out of homely love of the hearth, out of wild Indian legends that flowed down the Merrimac and English folk lore that flowered over seas and blew westward with a sniff of the brine in it, Whittier made his poems. But not out of these was born their greatness. That was distilled from his own fiber where it grew out of the rugged, honest, fearless life of generations whose home shrine had been that glowing hearth, whose love and tenderness welled within and overflowed like the scent of the old-time garden. To such a house and such a hearth sweetness climbs and nestles. To stand on the old door stone was to be greeted with dreams of meadows and lush fields, for wild mint has left the brookside and come shyly to the very door sill to toss its aroma to all comers. A spirit of the meadows that the barefoot boy loved thus dwells ever by his door and none may enter without its benediction. There is something Quakerlike in the wild mint, that 
dwells apart, unnoticed and wearing no flaunting colors, yet is so dearly fragrant and yields its sweetness most when bruised.

A stone's toss from the door I found his brook, its music muted by the summer drought so that you must bend the ear close to hear its song. With the foam brimming on its lip in spring the brook roars good fellowship, a stein song in which its brothers over nearby ridges join, filled with the potency which March brews from snow-steeped woods. Now, its March madness long passed, repentant and shriven by the kindly sun, it slips, a pure-souled hermit, from pool to pool, each pool so clear that in it the sky rests content, while water striders mark changing constellations on its surface. The pools are silent, only beneath the stones the passing water chirps to itself a little cheerful song which the vireos in the trees overhead faintly imitate. The trees love the brook's version best, for they bend their heads low to listen to it, beech and maple, white oak and red, yellow birch and white birch and black birch, hemlock and pine, dappling the pools with shade and interlocking arms across the glen in which 
the brook flows. In the dapple of shadow and sunlight beneath them ferns of high and low degree, royal and lady, cinnamon, interrupted and hay-scented, wade in the shallows and caress the deeps with their arching fronds. The blue flags that waved beside the water a month ago are gone, leaving only green pennants to mark their camp site for another year; and it is well that it is thus marked, else it were lost, for in the very brook bottom where the March flood crashed along have come to usurp it those tender annuals, the jewel weeds. Their stems almost transparent, their oval leaves so dark a green that it seems as if some of the dancing shadows found rest in them, they press in close groups into all shallow places and lean over the edges of the clear pools to admire the gold pendants that tinkle in their ears.

With these through the grassy shallows climb true forget-me-nots, slenderest of brook-side wanderers, each blue bloom a tiny turquoise for the setting of the jewel-weeds' gold. Thus shaded and carpeted the little ravine wanders down from the hills, and the brook goes with it, as if hand in hand, bringing to its side all sprightly life, a place 


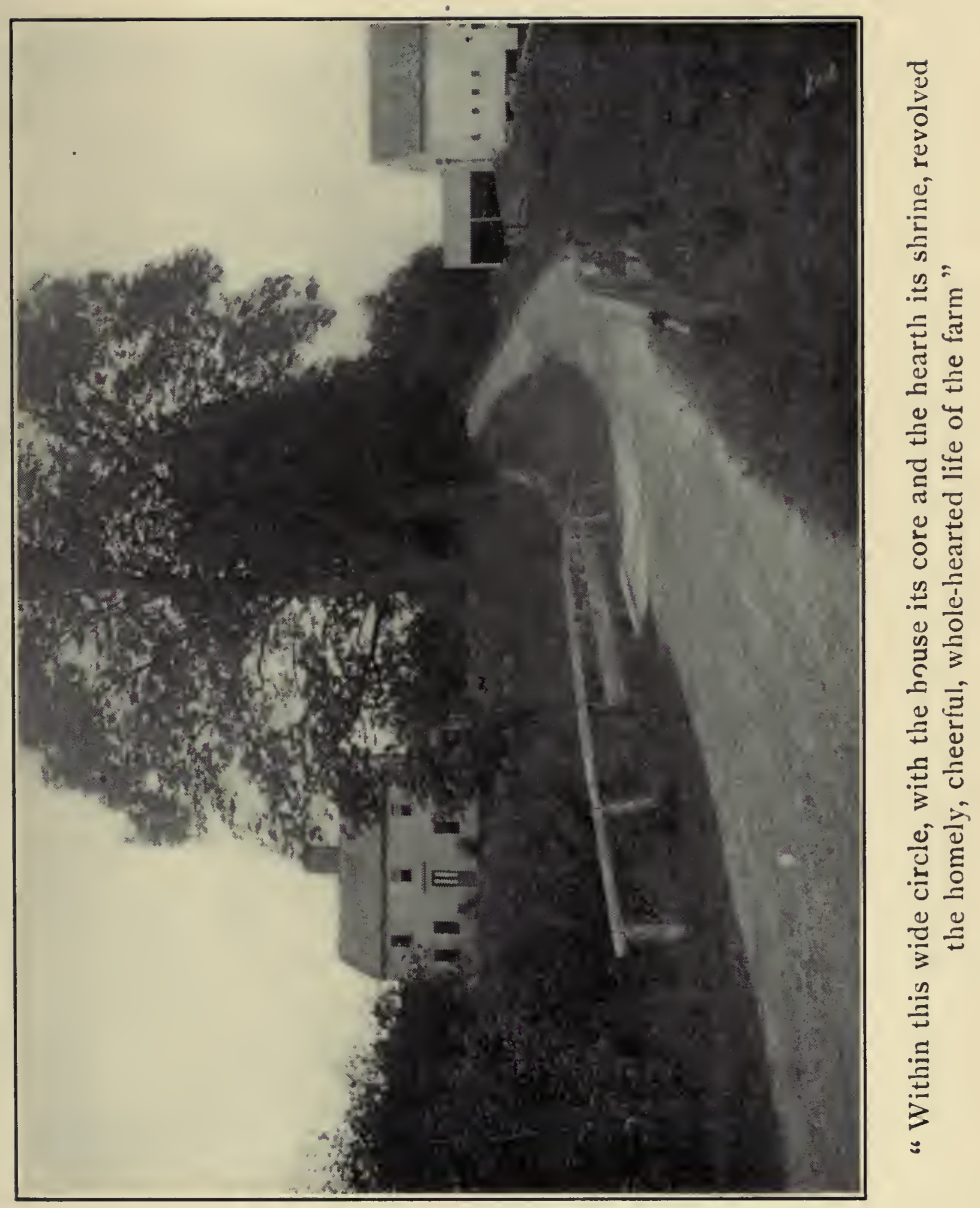



filled with boyhood fancies and echoes of boyhood laughter. A chewink, singing on a treetop up the slope, voiced this feeling. Someone has called the chewink the tambourine bird. His song makes the name a deserved one. It consists of one clear, melodious call and then an ecstatic tinkling as of a tambourine skillfully shaken and dripping joyous notes. Always before the chewink's song has been without words to me. This one sang so clearly "Whittier; ting-a-ling-a-ling" that I knew the bird and his ancestors had made the glen home since the boyhood of the poet, learning to sing the name that rang oftenest through the tinkle of the brook.

You begin to climb Job's Hill right from the glen, passing from beneath its trees to stonewalled mowing fields where rudbeckias dance in the morning wind, their yellow sunbonnets flapping and flaring about homely black faces. I fancy these fields were white with ox-eye daisies in the spring. They are yellow now with the sunbonnets of these jolly wenches. It is like getting from Alabama to New England to step over the last wall which divides the fields of the 
hill's shoulder from its summit, which is a closecropped cow pasture. Here the winds of all the world blow keen and free and you may look north to the crystal hills of New Hampshire whence come their strength. Eastward under the sun lies the pale rim of the sea. Kenoza Lake opens two wide blue eyes at your feet, and all along beneath you roll bare, round-topped hills sloping down to dark woods and scattered fields, as unspoiled by man as in Whittier's days. The making of farms does not spoil the beauty of a country; it adds to it. It is the making of cities that spells havoc and desolation. Through the pasture, up the steep slopes to the summit of Job's Hill, that seems so bare at first glimpse, climb all the lovely pasture things to revel in the free winds. Foremost of these is the steeplebush, prim Puritan of the open wold, erect, trying to be just drab and green and precise, but blushing to the top of his steeple because the pink wild roses have insisted on dancing with him up the hill, their cheeks rosy with the wind, their arms twined round one another at first, then round him as well. Somehow this bachelor bush which would be so austere re- 
minds one of the Quaker youth at the academy, surrounded by those rosy maidens of the world's people, one of whom we suspect he loved, yet could no more tell it than can the steeplebush acknowledge how sweet is the companionship of the wild rose and how he hopes it may go on forever. Stray red cedars stroll about the lower slopes and climb gravely, while juniper, in close-set prickly clumps, seems to follow their leadership. The canny, chancy thistle holds its rosy pompons up to the bumble-bees, that fairly burrow in them for their Scotch honey, and the mullein would be even more erect and more Quakerly drab than the steeplebush if it could. It is erect and gray, but just as it means to look its grimmest dancing whorls of yellow sunshine blossom up its stalk in spirals, the last one fairly taking flight from the tip. Among all these strays the yarrow, whose aroma is as much a New England odor as that of sweet-fern or bayberry. The aromatic incense of this herb follows you up the hill and seems to bring the pungent presence of the poet himself.

Job's steepest hillside drops you in one long swoop to the road which leads through woodland 
windings to the haunted bridge over Country Brook. The way itself is haunted by woodland fragrance and chant of birds innumerable, and in the freshness of the morning after the shower it seemed as if built new. The world is apt to be this way after rain. Yet if the vivid morning sun and exhilarating north wind had driven all ghosts away there had been necromancy at work. All the day before the blossoms on the staghorn sumac had been of that velvety pink that rivals the wild rose. Over night they had turned a warm, rich red. Autumn brings this richer, more stable color to the sumac blooms as they ripen toward seed time, but it does not do it in July, over night. The pukwudgies had been at work, painting with the rain, filling the sumac heads with it till they hung heavy. The water had massed the tiny pubescence of the blooms till pink had deepened into red and autumn had seemed to come for the sumacs in a night. It took the sun and the wind all day to dry them out and bring back the witchery of pink that the necromancy of the rain had banished. But the spell was not altogether broken, nor will it be till autumn has worked its 


\section{AT WHITTIER'S BIRTHPLACE}

will with the world about Country Brook. Out of the birches the fresh wind threshed here and there yellow leaves that fluttered like colias butterflies before it. There and here among the sumacs hung a crimson leaf, more vivid in its color than the blossoms or the berries could ever be, and as in the woodland all news flashes from shrub to shrub and from creature to creature, so it seemed as in the hint of autumn, first born, a simulacrum merely, in the wet sumac heads, had gone by birch leaf messengers to all distances. Along the way flashed out of invisibility the yellow of tall goldenrod heads and the blue and white of the earliest asters and, once materialized, remained.

August may bring vivid heat and wilting humidity if it will. The witches' twilight had brought down the Merrimac from the far north the flavor of autumn which is later to follow in full force, nor will it wholly leave us again. The ghostliest thing about Country Brook was a sound which seemed to come up it from the cool depths of the woods into which it flows, a soft breathing sigh, now regular, now intermittent, as if a spirit 
of the woodland slept peacefully for a little, then gasped with troubled dreams. Seeking to discover this ghost I found a little way along the road from the bridge a broad grassy avenue that led with a certain majesty in its sweep as if to some woodland castle whose people were so light-footed that they wore no paths in their broad green avenue. Yet after all it led me only to a wide meadow where the sighing I had heard was that of the grass going to sleep under the magic passes of a mower's scythe. No clatter of mowing machine was here, just the swish of a scythe such as the meadow has heard yearly since the pioneers came. There were deer tracks here along the margin of Country Brook, and all the gentle wild life of woods and meadows seemed to pass freely, without care or fear.

And so I found all the country about the Whittier homestead an epitome of the free, cheerful, country life of the New England of a century ago. They lighted a fire for me in Whittier's fireplace - and as the rose glow on the walls of the old living-room brought back the hearth-cheer of bygone years, as the witches, daintily making 


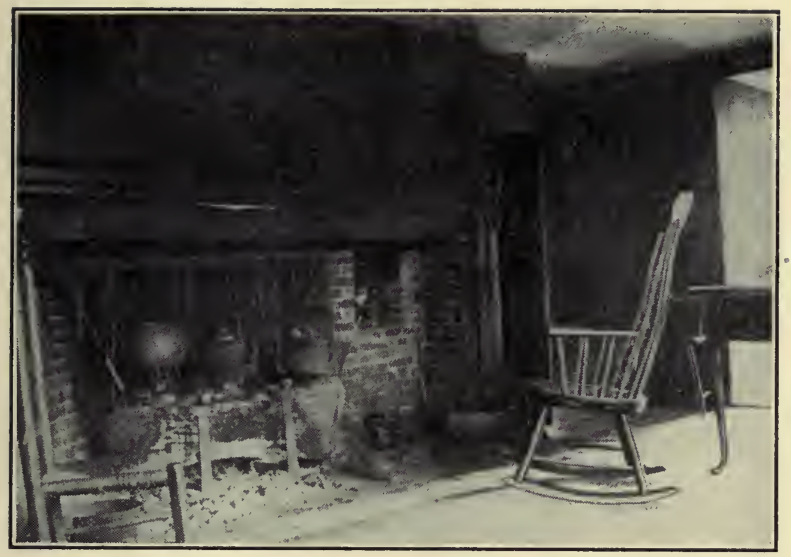

"Watching the crane and pendant trammels grow black against the blaze"

See page 18

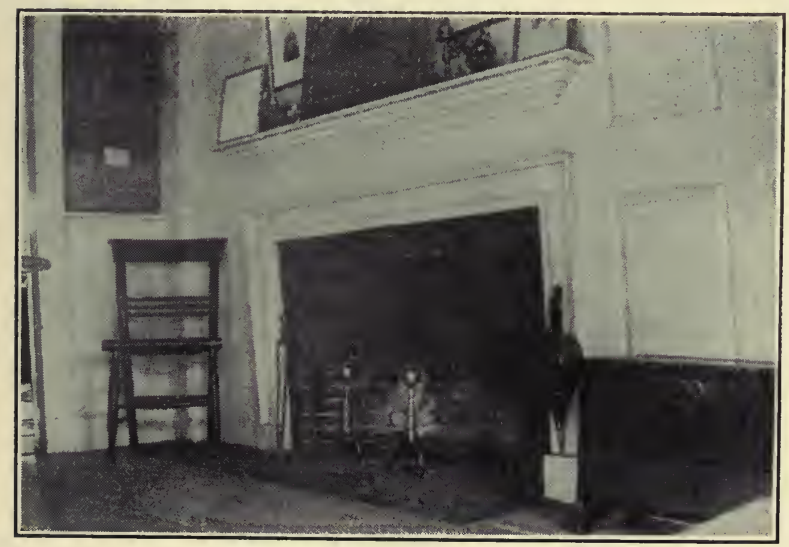

A corner of the room in which Whittier was born 



\section{AT WHITTIER'S BIRTHPLACE}

tea without under the lilac bush, brought the romance and legend of the olden time to the threshold, so the crackling draft of the fire up the deep throat of the chimney seemed to draw in to the place the free, hearty, farming, wood-loving life of the men of the earlier centuries out of which the poet drew what was best in him, to be given out in unforgettable verse to us all. If such a place was ever lonely it was that gentle and desirable loneliness which great souls love. 


\section{IN OLD PONKAPOAG}

Glimpses from a Study Window of

Thomas Bailey Aldrich

The study where Thomas Bailey Aldrich wrote some of his daintiest verse looks forth upon a sweet valley. Down this valley prattle clear-eyed brooks that meet and grow, and water lush meadows filled with all lovely things of summer, while low woods beyond set a dark green line against the sunsets. Looking toward these of a day when rosy mists tangle the sun's rays and anon let them slip in arrow flight earthward, we have pictured for us how

"We knew it would rain, for all the morn,

A spirit on slender ropes of mist

Was lowering its golden buckets down

Into the vapory amethyst."

Wherever written, this and a hundred other dainty things seem to flock into the tiny valley upon which he looked from the study window of 


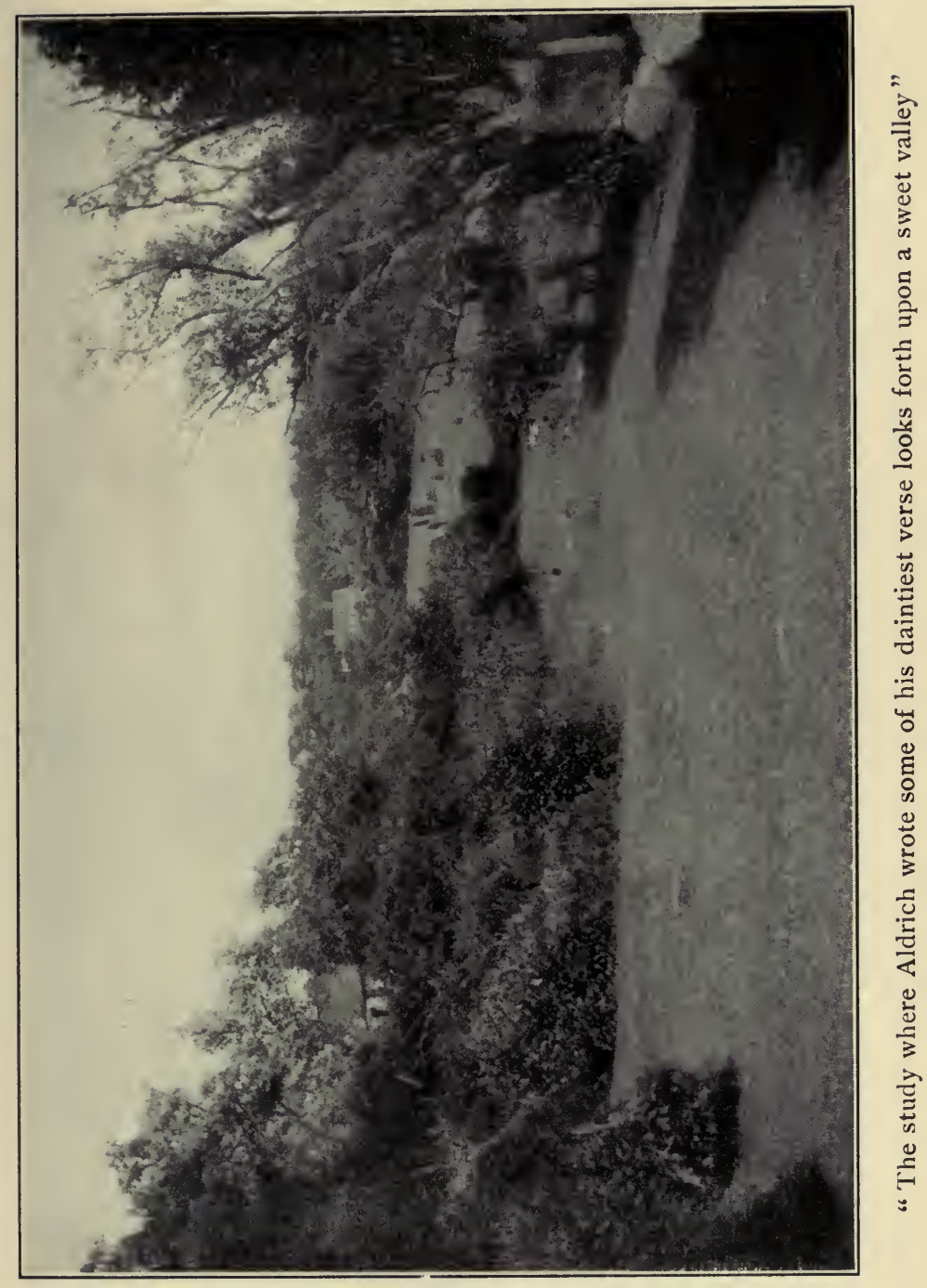



his later life in what was then the quaint old village of Ponkapoag, as if the flowers of fancy to which he gave wings still hovered there. At nightfall it is easy along these meadows to

"See where at intervals the firefly's spark

Glimmers and melts into the fragrant dark;

Gilds a leaf's edge one happy instant, then

Leaves darkness all a mystery again."

The quaint old Ponkapoag of not so very many years ago is changing fast. The trolley car passes and repasses in what was once its one street. The real estate man has come and modern houses grow up over night, almost, in the empty spaces over the old stone walls, while in the surrounding pastures and woodland appear the mansions of those who seek large estates not too far from the city. Suburban life begins to crowd Ponkapoag and the little self-centered country village of the genuine New England type passes. Most, however, of the sturdy old houses of a century or more ago remain and much of the beauty of the country round about them. On Sundays and holidays Ponkapoag Pond teems with an uproarious holiday crowd, but on weekdays one may still enjoy its beauty unmo- 
lested, hear the blackbird's music tinkle along the bogs, and see the pond lily, the pure white spirit of Miantowonah, sit on the water. On such days Ponkapoag Pond, "the spring bubbling from red earth," seems still to belong as much to the Indians, whose favorite fishing ground it was, as to us latter-day usurpers, and the outlook across it to the dusky loom of Blue Hill is as wild now as it was in their day.

From the north-facing window of the poet's study you may see the hill again, with all its beauty of color which changes with the whim of the day. At dawn of a clear morning it looms blue-black against the rosy deep of the sky. At noon it looms still but friendly and green, so near that the eye may pick out the shape of each tree that feathers the jutting crags. At noon of such a day Ponkapoag hill with its houses bowered in green seems a part of it, the half mile of intervening space making no impression on the eye. As the sun sinks a haze rises from the rich farming land which lies level between the two hills. The spirit on slender ropes of mist is at work, and through this vapory amethyst the larger hill withdraws into 
soft colors of blue that grow violet purple with the coming of dusk below and the rosy afterglow of reflected sunset in the sky above. Captain John Smith named the range "The Cheviot Hills" in recollection of old England, but all the countryside named it Blue Hill because of the changing wonder of its coloring, which is a constant delight to the eye. On stormy days when gray northeasters send torn clouds, fragrant with the tonic smell of the brine, whirling over it, the hill looms misty and vague, as if it might well be a mountain scores of miles distant, instead of the single mile it is along the straight road. On such days all the wild sea myths and northland sagas seem to be blown in over the hill barrier and trail down from the skirts of the clouds into the secluded peace of Ponkapoag valley. Hence, to those who dream, come sea longings.

"The first world-sound that fell upon my ear Was that of the great winds along the coast Crushing the deep-sea beryl on the rocks The distant breakers' sullen cannonade.

Against the spires and gables of the town The white fog drifted, catching here and there At over-leaning cornice or peaked roof, And hung - weird gonfalons. The garden walks 
Were choked with leaves, and on their ragged biers

Lay dead the sweets of summer - damask rose,

Clove pink, old-fashioned, loved New England flowers.

Only keen, salt-sea odors filled the air.

Sea-sounds, sea-odors - these were all my world.

Hence it is that life languishes with me inland."

Infinite variance of changing moods has the hill which lifts such abrupt crags above the Ponkapoag plain. At times the poet may have seen it as it was one day not long ago, when a great thunderstorm, born of the sweltering, blue haze of a fiercely hot July day, swept across it. On that day the hill withdrew itself into the menacing black. sky, looming against it, then vanishing, becoming part of a night like that of the apocalypse, in which hung the observatory and the higher houses of Ponkapoag hill "as glaring as our sins on judgment day." The storm in which the miracle of "The Legend of Ara-Cœli" was wrought could not have been blacker than the sky, nor the face of the monk, when he saw the toes of the bambino beneath the door, whiter than gleamed those houses. The weirder, greater things of nature loom often through the poems of the man who looked upon such scenes from the study window in what was 
"The Bemis Place" of the elder days of Ponkapoag village. It seems as if all the lighter, sweeter fancies that laugh or slip, tear in eye, through his verse, whirled like rose petals on summer winds or danced like butterflies into the little valley on which the westward study windows looked. Through this, right in the foreground, flows Ponkapoag brook, and on it falls slowly into decay an ancient mill, a relic of the early days of the village. The old dam no longer restrains the water which gurgles along the stones below it, humming to itself a quatrain which never was meant for it, but which voices the fate of the shallow mill pond, which has been empty for so many long years that it is no longer a pond but a tiny meadow in which cattle cool their feet and feed contentedly. Here the spendthrift brook sings contentedly:

"The fault's not mine, you understand;

God shaped my palm, so I can hold But little water in my hand

And not much gold."

In the meadow and along the brookside blooms to-day the Habenaria psycodes, the smaller purple- 
fringed orchid, its dainty petal-mist rising like flower steam of an August noon, a shy child of woodland bogs, which often runs away out into the open meadow to hear the blackbirds sing. This year I have not found the larger fringed orchid, the Habenaria fimbriata, which comes to the meadow less often, a flower which one might fancy the mother of the other, coming to lead the truant home again to the seclusion of the woodland shadows. In all the fairy nooks of this valley ferns spring up like vagrant, delicate fancies that are real while you hold them in close contemplation, yet vanish into the green of the surroundings, as the form of a poet's thought fades when you take your eye from the printed page, though the thought itself lingers long in your memory. In the shallow meadow that was once the tiny pond stands, shoulder high to the feeding cattle, a solid, serried phalanx of the tall sagittaria, its heart-shaped, lanceolate, pointed leaves aiming this way and that, as if to fend it with keen tips from the eager browsers. These wade through it indeed, but do not feed on it, plunging their heads deep amoung the spear points to gather the tender 


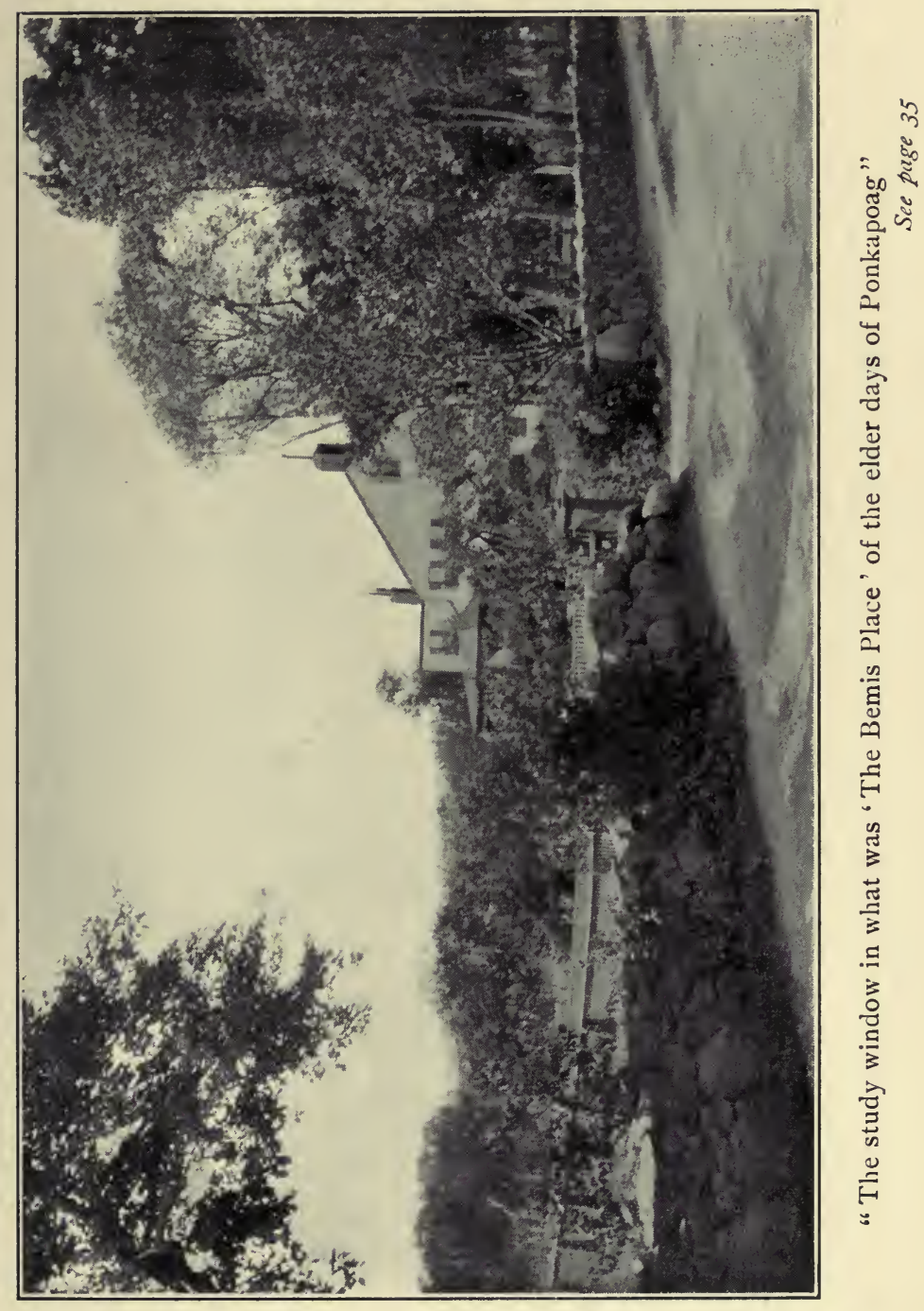



herbage beneath. While I watched them two of these, half-grown Holstein heifers, bounded friskily to the hard turf of the cedar-guarded pasture above and raced in a satyr-like romp over the close turf and among the cedars for a time. It was as if they knew that Corydon had just vanished up that roadside in Arcady in pursuit of the maiden that the Pilgrim described to him, and the valley was free from all supervision for a time. The white spikes of bloom on the waterplantain nodded to let them pass, and nodded again as if they too knew why the satyrs frisked and on what errand the shepherd had gone.

Daintiest of embodied thoughts which flit along this sequestered valley are the butterflies. This is their feasting time of year, for now the milkweed blooms hang crowded umbels of sticky sweetness that no honey-loving insect can resist. Commonest of these by the brookside is Asclepias cornuti with its large pale leaves and its dull greenish-purplish flowers. It is rather odd that out of the same brook water and the salts and humus in the black earth through which it flows one plant should grow these dull, heavy, loutish flowers, 
while just beside it, perhaps, the Habenaria psycodes gets its misty delicacy of purple bloom from the same source. With plants as with people it is not that on which we feed nor the spot on which we stand that counts in the final moulding of character. Some subtle essence, some fire of spirit within the orchid makes its bloom. Some grosser ideal within the milkweed matures in the dull, sticky umbels. Thus within the town, attending the same schools, and fed by the same butcher and baker, one boy grows up a poet and another a yokel. Even in the same family you may see it, for the milkweeds are not all alike. Along the dry hillsides the Asclepias tuberosa gives us bright orange flowers, exudes little if any stickiness, and even gets a better name from the botanist, being called the butterfly-weed.

But however gross and homely the milkweed blooms the butterflies find rich pasturage there and sip and cling till they fairly fall off in satiety. Winging to the milkweed out of the chestnut and maple shade of the deep wood comes Papilio turnus, striped tigerwise with rich yellow and black. Out of the long saw-edged grass that grows long 
in the meadow and bows before the wind as do fields of grain sails Argynnis cybele, the great spangled fritillary, the fulvous glory of his broad wings spangled beneath with silver, as if he carried his coin of a fairy realm with him wherever he goes. Over the very pine tops soars the monarch, his rich dark red and black borne on wings that are the strongest in butterfly flight. These three, most conspicuous sprites in the meadow tangle, give rich coloring and the poetry of motion as they bear down upon the milkweed blooms, to leave them no more save for short flights taken merely to secure a better strategic position on the umbels, till they are cloyed with the rich nectar, and smeared with the sticky exudation which the plant puts out on the blooms for purposes of its own. I fancy the butterflies are vexed and indignant at this stickiness which smears their legs and makes yellow pollen masses cling to them when, satiated and lazy, they next take flight. Yet the whole is cleverly arranged. On the smeared legs as they sail away cling pollen masses which the insect is not likely to get rid of till it lights on another head of bloom, very likely one of some distant 
plant. There the sticky masses cling closer to the quaint horns which each bloom protrudes from behind the anthers, there to drop pollen grains on the stigma and insure the cross-fertilization of the flower. Thus unwittingly butterfly and bee as they sail about the sun-steeped meadow suffer discomfort for their own good, insuring vigorous crops of milkweed for another summer, for themselves or their descendants.

With these comes the smaller, Colias philodice, the sulphur, bringing with him the very gold of the sunlight. Colias philodice has many changes. Sometimes the black margins of his wings are missing and his gold melts into the sunshine and vanishes before your eyes. Another may come that is white instead of gold, a wan ghost of a colias that seems born of the mist instead of the sunshine and to vanish into nothing when he flies away, as mist does. Sometimes the colias flies up into the wood and lights, and as I come to the spot where I think I saw him stop I find nothing but a single bloom of the golden gerardia which now slips from glade to glade all along where the hardwood growth comes down to meet the meadow 
grasses. The gerardia might very well explain all this if it would, but it is born close-mouthed. If you will look at the yellow buds which later open into the golden bells into which the bumble-bees love to scramble, bumbling as they go, you will see how tightly their lips are pressed together. No word can you get from these by the most insistent questioning, and even when they open it is easy to see that they have learned that silence is golden.

The Baltimore butterfly, wearing Lord Baltimore's colors of orange and black, is a common visitant to these meadows, too. He loves to tipple the lees of the milkweed blooms, but he does not frequent the meadow for that. It is because along its shoreward edges where the cool water oozes from black mud grows his home plant, the turtlehead. On this he was born and to it he goes for the housing and feeding of his children. Like Gerardia flava, Chelone glabra is close-mouthed, but its silence is a wan white one which only blushes pink with embarrassment when questioned, but yields no reply. You cannot learn any mysteries of the meadow from these. 
Palest and most ghostlike of all flowers that one finds as he climbs from the meadow to the woods beyond is that of the Monotropa uniflora, or Indian pipe. Round about it its cousins, the pyrola and the pipsissewa, grow green leaves and show waxy white or flesh-pink blossoms. The only color in the Indian pipe is that of the yellow stamens, which shrink in a close circle within the wax-white bloom that stands on a scaly, wax-white stem. A very ghost of a flower is this, nor may we account for its ghostliness. When, long ago, Miantowonah fled to drown her grief in the lake and later rise from it the spirit of a flower which is the regal white pond lily that scatters incense all along the borders of Ponkapoag Pond, her Indian lover followed, too late to prevent the sacrifice. Did he drop his peace pipe in the race through the wood, and did this ghost flower spring from the spot, a faintly fragrant, almost transparent ghostly reminder of it? If so, it has passed into no legend.

Coming back through the meadow, with its butterfly sprites of fancy dancing among the flowers, I find one which always seems a reminder of the poet's work at its daintiest and best. That 
is the bloom of the wild caraway. Here is a mist of delicate thought which speaks to you with lacelike beauty. Nor does the closest inspection reveal any fault. The bloom appeals as a delightful bit of sentiment, at first glance. It is only as you examine it minutely that you marvel at its exquisite workmanship. However carefully you pick it to pieces you find each part perfect and as admirable in its ingenuity as in its appeal to the imagination. And after you have done this you pass on, touched with the white purity of it and bearing far a gentle, aromatic pungency which is the essence of the parent stem that bore the bloom. 


\section{IV}

\section{AT THE ISLES OF SHOALS}

\section{The Island and the Garden which Celia Thaxter Loved}

The poppies that grow in Celia Thaxter's garden nod bright heads in welcome to all who come. It is as if the sunny presence of their mistress dwelt always in the spot, finding voice in these blooms which are so delicate, yet so regnant in spirit. To these all the other flowers which speak of the homely virtues, marigolds and red geraniums, coreopsis and pinks and love-in-a-mist, seem subordinate at first approach, though they occupy the bulk of the garden, which seems to epitomize the life of the mistress who tended it so long. There is no square of it without its rich aroma of love and womanliness, yet it is the vivid personality of the poppies, flowers for dreams, which touches first the comer from the outside world.

Round about the garden lies Appledore, the largest of the Isles of Shoals, rocked gently on 


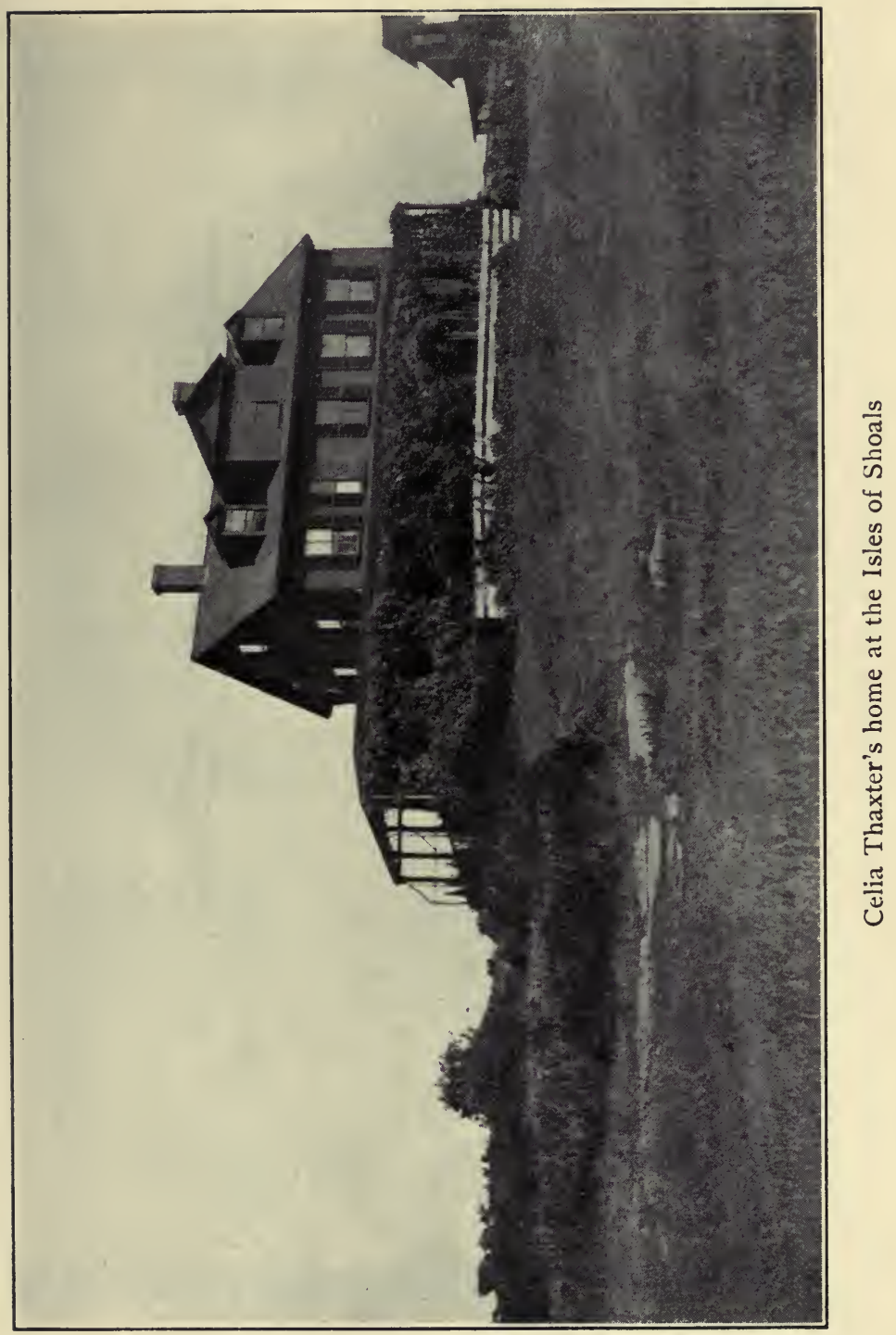



the bosom of blue seas, its margin flashing with beryl and pearl where rocks and breakers touch, its rounded ridges white and green again with the granite of which it is built and the verdure with which it is clothed. Over it all bends the blue of the summer sky, and as you look up to this from the little garden it seems to lean lovingly upon the hill which is the island's highest part, heaven so near that the scent of the flowers may easily pass to it by way of the little winding path. To climb this path yourself is to find the sky not so near after all. Standing on the summit, you realize first the depth of its great dome and the wide sweep of sea that rims the islands round. Here are but gray ledges that rise out of an immensity which dwarfs them. Far to the north and west is a thin, blue line of land that lifts in the farthest distance the peaks of the White Mountains. All else is but a vast expanse of sea that seems as if it might rise in a storm and overwhelm these rocks that it has washed so white and smooth. Somewhere to the eastward of our coast lies, they tell us, the lost Atlantis, submerged beneath this great sweep of blue that smiles beryl 
and laughs pearl-white in wave crests. Who knows but this granite dome of Appledore on which we seem to loom so high in air is the westernmost peak of the vanished continent? We are but seventy-five feet above the sea's surface. It must be the thought of its depths that gives us the feeling of being upon a mountain peak. For all that, this height and distance so make us dominate the other islands that they seem but ledges, wave-washed reefs in comparison, and one wonders how such of them as have buildings on them hold them during the sweep of winter gales and full-moon tides.

In the smile of summer it is easy to forget this. It is but a step from the rough rocks of the island to the dense verdure of its shrubbery. At first one wonders where the soil came from that nourishes herb and shrub in such profusion. Here among the gray granite grow most of the beauties of any shore-sheltered New England pasture. Here is elder showing white, lace-like blooms, bayberry and staghorn sumac each striving to overtop the other, wild cherry and shadbush, and beneath and around these low-bush black huckleberries, rasp- 
berries and blackberries, the last two blessing the tangle with fruit. Among the grasses grow yarrow, St. John's wort, mullein, toad-flax, cranesbill, evening primrose and other herbs, while Virginia creeper and fragrant clematis make many a spot a bower of climbing vines. Not only do all these familiar pasture folk grow here, but in many instances they seem to grow with a luxuriance that exceeds that of their favorite shore locations. Their tangle makes passage difficult except by established paths, and the road which circumnavigates the island is cut almost as much through the compacted shrubbery as through the rough rocks along the tops of the cliffs. Rainfall collects in the hollows of the granite in some places and makes miniature marshes, and in one spot a tiny pond which is big enough to supply ice to the islanders, filling to the brim with the winter rains and in some winters freezing pretty nearly solid. In August this pond, which is high in the middle of the island, is dry, its bottom green with rushes and its sides rampant with the spears of the blue flag.

Often in the tiny valleys in the heart of the island, surrounded by its dense shrubbery, you lose sight 
of the sea, but you cannot forget it. However still the day, you can hear the deep breathing of the tides, sighing as they sleep, and a mystical murmur running through the swish of the breakers, that is the song of the deep sea waves, riding steadily in shore, ruffled but in no wise impeded by the west winds that vainly press them in the contrary direction. However rich the perfume of the clematis the wind brings with it the cool, soothing odor that is born of wild gardens deep in the brine and loosed with nascent oxygen as the curling wave crushes to a smother of white foam. It may be that the breathing of this nascent oxygen and the unknown life-giving principles in this deep sea odor gives the plants of Appledore their vigor and luxuriance of growth. Certainly it would not seem to be the soil that does it. Down. on the westward shore of the island, in an angle of the white granite, where there was but a thin crevice for its roots and no sign of humus, I found a single yarrow growing. Its leaves were so luxuriant, yet delicate, so fern-like and beautiful, such feathery fronds of soft, rich green as to make one, though knowing it but yarrow, yet 
half believe it a tropic fern by some strange chance transplanted to the rugged ledges of the lonely island. With something in the air, and perhaps in the granite, that makes this common roadside plant develop such luxuriance, it is no wonder that other common pasture folk, goldenrod and aster, morning glory and wild parsnip, and a dozen others, growing in abundant soil in the tiny levels and hollows, are taller and fuller of leaf and petal than elsewhere. In the richness and beauty of the yarrow leaves growing in the very hollow of the granite's hand, as in the height and splendor of the Shirley poppies in the little garden, one seems to find a parallel to Celia Thaxter, whose own character, nurtured on the same sea air, sheltered in the hollow hand of the same granite, grew equally rich and beautiful.

All Appledore, indeed all the Isles of Shoals are built of this rock, which is white in the distance, but which near to shows silver fleckings of mica that flash in the sun. Through the granite run narrow veins of quartz that is as hard as flint, but that has scattered among its crystals also a silvering of these mica flecks 
which are in strange contrast to the tiny pin points of a softer, darker rock which one finds evenly sprinkled through the white. This, dark rock softens to wind and weather first and leaves these white cliffs honeycombed with the tiniest of fissures, so that they are as rough to the hand as sandpaper. Dykes of trap run through the island, and as this rock too is softer than its casing the winds and waves of centuries have worn it away, leaving chasms down which you may walk to the tide, between the sheer cliffs. One such chasm runs quite across Appledore from east to west near the northern end of the island, almost cutting off a round dome of granite from its fellow rock. The soil lies rich in this narrow hollow between ledges, and many things grow in it, lush with leaves and beautiful with bloom. Here the shadbush had already ripened its fruit. Here the island's one apple tree grows vigorously, though it dares not lift its head above the level of the rocks against which it snuggles, lest the zero gales of winter nip it off. Crowding round it grow wild cherry and wild rose, elder and sumac and huckleberry and chokeberry, all eager 


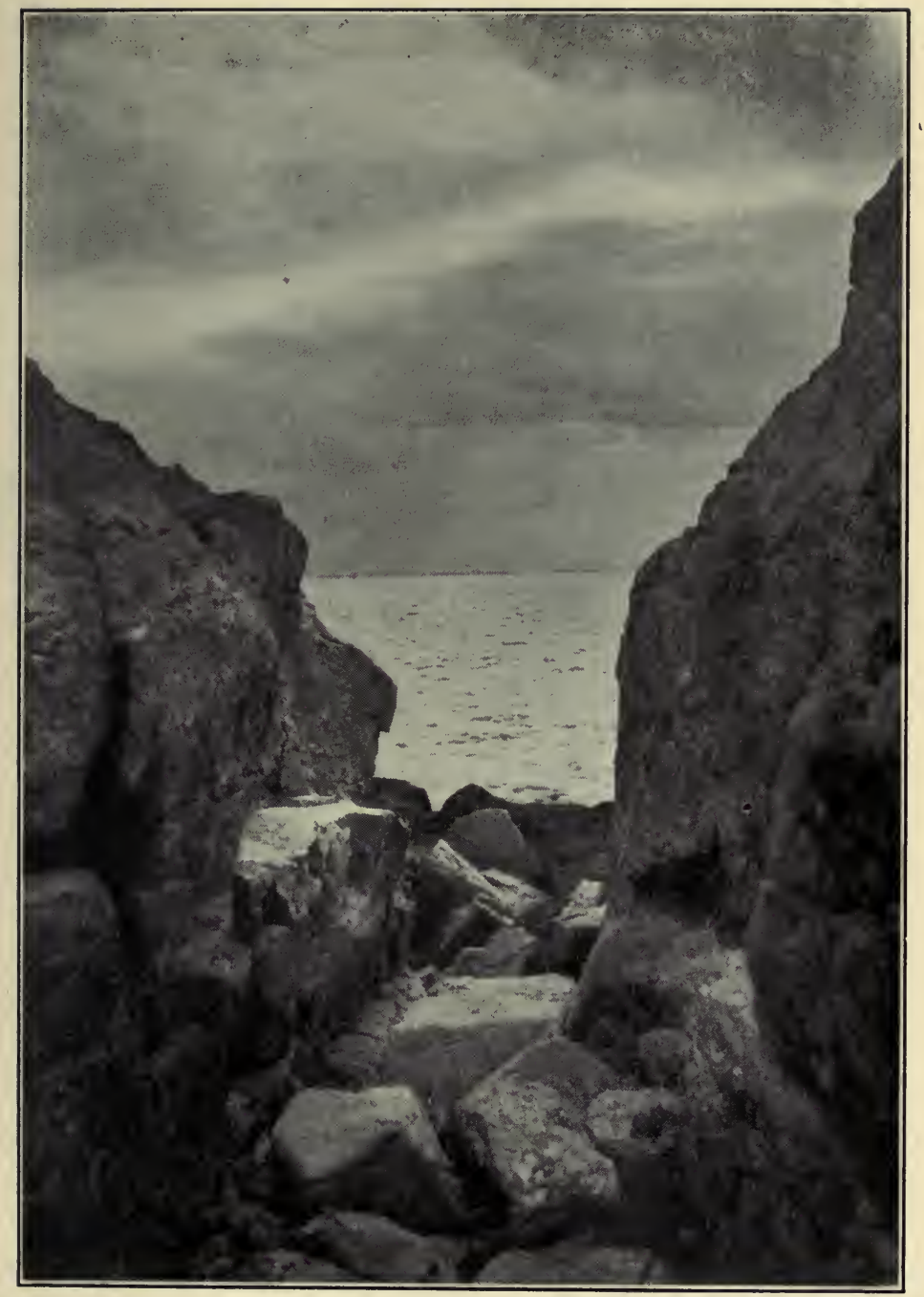

"Chasms down which you may walk to the tide between sheer cliffs" 

to fend it from rough winds in that friendliness which seems, like foliage, to flourish in the place. Here is a soft turf of grass in which grow violets and dandelions, both spring and fall, and plantain, cinquefoil and evening primrose have come to make the place homelike. If rough winds blow here rougher rocks fend them off, and though they may whistle over the tops of these in the little valley between there is quiet, and floods of sunshine gather and well up till the place is full.

This tiny valley dips toward the sea at the west and broadens to a meadow where I fancy the islanders have at some time grown cranberries, for a few plants remain. For the most part, however, this meadow is set thick with the green spears of the bog rushes which grow so close together that there is little room for anything else. To crush your way in among these is to pass through a very forest of dark green lances whose tips stretch upward to stab your chin, yet burst into bloom from the sides near these tips, as if the full life within them which could not be restrained yet which finds no outlet in leaves, exploded in a lance pennant of olive-brown beauty. 
A Maryland yellow-throat whose nest stands empty in the grass on the borders of this little, lance-serried marsh fluttered and chirped and clung among these rushes and from the top of a near-by bayberry shrub a song sparrow trilled a note or two, despite the fact that it is moulting time and few birds have the heart to sing in dishabille. Nightfall brought no sound of frog voices from this little marsh, yet I cannot fancy it in spring without a hyla or two to pipe flute notes from its margin. Near this I found the one ophidian of the island, a beautiful, slender, graceful green snake, little more than a foot long. This lovely little creature feeds on crickets and insect larvæ and is the very gentlest snake that ever crawled. Jarred by my footfall in the grass he glided away among the tangle, trusting to his coloration, which is a perfect grass green, to hide him, which it soon did. If Appledore must have its serpent no sweeter-natured nor lovelier variety could be found. If modern Eves sit upon the rocks of moonlight nights and listen to this one's promptings one can scarcely blame them.

Under the eaves and under the verandas of the 


\section{AT THE ISLES OF SHOALS}

houses are the nests of barn swallows, gray mud stippled up against a rafter, the fast-growing young almost crowding one another out. So gently familiar are these birds, and so little afraid of people, that one has built a nest under the frequented piazza of the big hotel, and the parent birds flit back and forth unconcerned by the rows of guests that often take chairs and watch the nestlings for long periods. Not only do the parents feed their young while thus watched by crowds but a few feet away, but they fly in under the veranda and capture food right over the heads of the promenaders with equal freedom from fear. Barn swallows are usually friendly, confiding birds. They seem here to have caught the sense of protection and safety which comes to all on the little island, and become even more fearless. It is much the same way with the tree swallows, which, having no hollow trees, build in bird boxes all about. These already have young in flight. Standing on the cliffs you see their steel blue backs as they swirl with the little waves in and out among the rockweed at low tide, seeking their food very close to land or water. 
Often the young sit on some safe pinnacle and are fed there, the old bird flashing up, twittering, delivering a message and a mouthful at the same time, then flashing away again, whirling and wheeling, never beyond call of the eager fledgling. Often the fledgling soars into space, hardly to be distinguished then from the older bird, and twitters back and forth near the parent. Then when the latter comes with a mouthful the former simply poises fluttering while the old bird dashes up, twitters and feeds, and is off again in the flash of an eye, so fleet of motion, so agile of turn, that it puzzles the watcher to follow the course of flight.

At the bottom of the tide the rocks over which the tree swallows swirl with the waves are a golden olive with the sun-touched tips of the carrageen. Higher up the boulders lift their heads with the air-celled rockweed falling all about them like wet hair. Some of these tresses hang down in golden luxuriance, others are dark, almost black, as if blondes and brunettes were to be found among tide rocks as among men. Between these rocks are still pools of brine where mussels and 
crabs wait the deliverance of the full sea and kelp waves its long, dark-olive, ruffle-margined banners. Down among these with the ear close to the smooth, undulating surface you may catch the eerie plaint' of the whistling buoy off the channel some miles to landward, telling its loneliness in recurrent moans.

Up on the rocks again in the bright sunlight, one finds the land birds numerous, chief among which are the song sparrows. In the secluded peace of the place these also, evidently making their summer home here and nesting in the shrubbery that is all about, have lost most of their fear of man and will approach very near to gather crumbs about your feet. A small flock of robins goes by, stopping a moment to feed, then taking wing again as if practising for that southward migration which will begin before very long. Olive-sided flycatchers, already working toward the sun, flit to catch flies and light alternately almost as if playing leapfrog from bush to bush. So far as I have observed, the olive-sided flycatchers do most of their migrating thus, hippetyhop from perch to perch, with a fly well caught 
at every hop and well swallowed at every perch. A kingbird sat haughtily, as if mounted, on a stub, monarch of all he surveyed, now and then giving his piercing little cry and sailing out to the destruction of a moth or beetle, then sailing leisurely back again. A lone gull fished and cried lonesomely in the surf, and a few pairs of sandpipers slipped with twinkling feet along the rocks, feeding in the moist path of the receding wave and lifting on long, slender wings to safety at the crash of the next one. These were the only day birds to be found of a pleasant day at Appledore. Monarch butterflies were plentiful, migrants these over the seven miles or more of sea between the island and the mainland. A few cabbage butterflies fluttered white wings over the Cruciferæ which grow in the vegetable gardens of the place. The cabbage butterflies may well be natives, and so might that other which danced away so rapidly that I could not be sure of him, though I am confident that he was either a hunter's butterfly or an angle-wing. Yet these, too, may have come from the mainland on a still day or with the wind right and not too 


\section{AT THE ISLES OF SHOALS}

strong, such extraordinary distances do these seemingly frail and impotent insects cover sometimes. Honey bees from hives ashore make a regular business of flying to the islands and back laden with honey. Students of bees ordinarily give them a range of two and a half to four miles, yet these Appledore bees must come at least seven miles and probably ten for their harvesting.

At nightfall three great blue herons came flapping out from the mainland to fish among the kelp and rockweed of the outlying reefs. All along the western horizon the soft blue line of land began to melt into the steel blue of the sea that the sunset fire seemed then to temper to a violet hardness. The southwest wind had blown the sky full of blowsy cumulus clouds that were touched with fire from the setting sun, yet in the main had the color of the steel sea, as if they were the flaked dross from its melting. Then the sun for a moment burned through the thin blue line of land and set the sea ablaze with a gentle radiance of crimson and gold that slipped along the level miles and wrapped the blessed isles in its arms, radiant arms that unclasped themselves in 
a moment, lifted above the islands in benediction and then passed. The poppies in Celia Thaxter's garden folded their two inner petals like slim hands, clasped in prayer, lifted trustfully to the sky.

A little way from the garden that she loved and tended so long is Celia Thaxter's grave, on a knoll to which the sky bends so gently that it seems as if you might step off into it. Up to the smooth turf of this knoll crowd all the pasture shrubs that she loved, sheltering it from the wind on three sides and letting the sun smile in upon it all day long without hindrance. The sumacs come nearest as if they were the very guard of honor, but close behind them press the wild roses, the St. John's-wort, the evening primorses and even the shy white clover slipping in between the others, very close to the ground, and tossing soft perfumes out over the brown grass. On the grave itself someone in loving remembrance scatters the petals of red geranium, which seems of all things the home-loving, home-keeping flower. The poppies are for poets' dreams which write themselves in the dancing morning wind, 


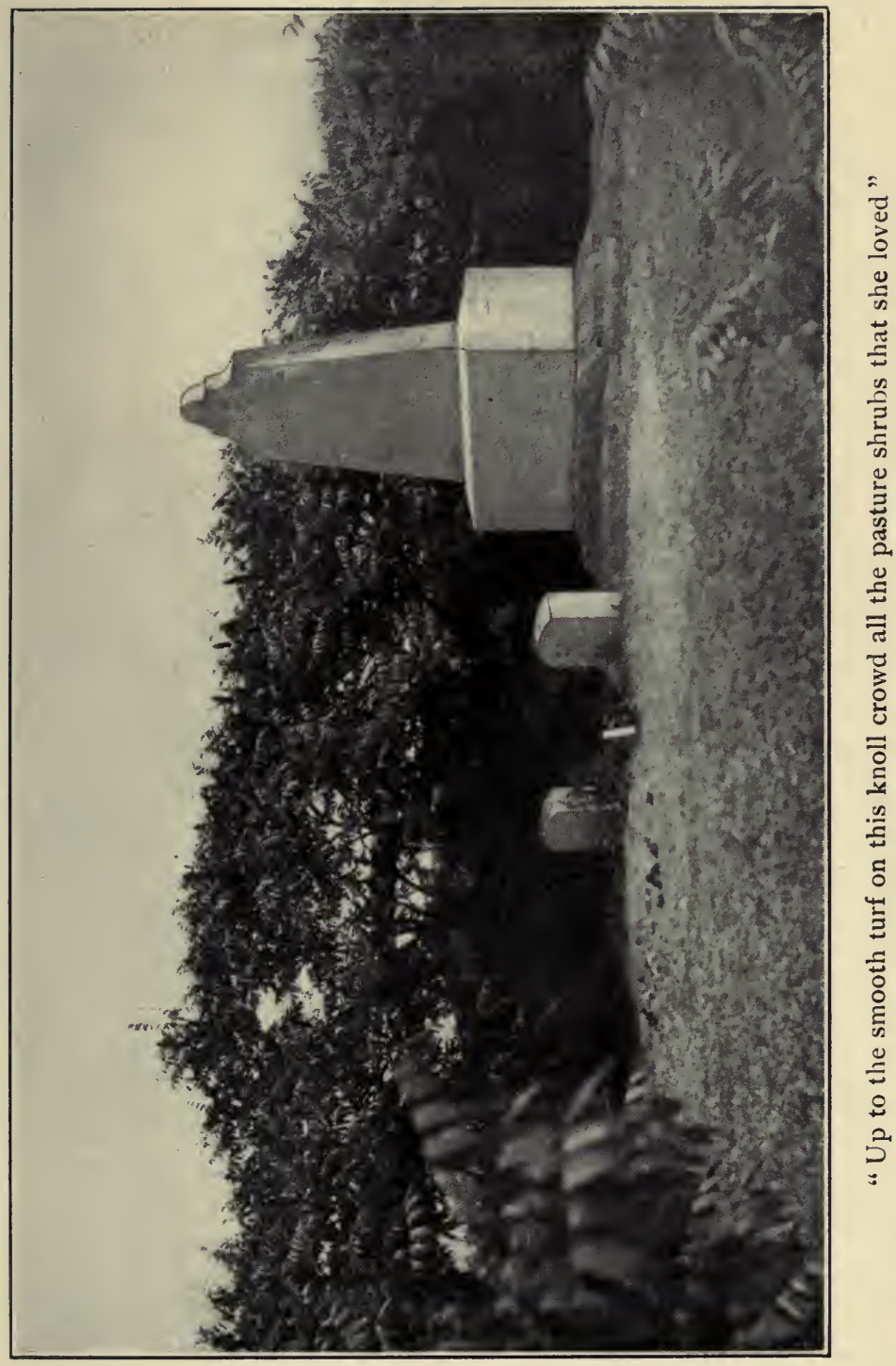



clasp hands in prayer at sunset, and flutter away. Red geraniums seem born of the fireside where home has been since fire first came down out of heaven. Dreams and hearthfire both were dear to the sweet lady of Appledore, and both flowers commemorate her there. 


\section{V \\ THOREAU'S WALDEN}

$A$ Survey of the Pond and its Surroundings

He who would know Thoreau's Walden will do well to bathe in it. His first plunge may well be in Thoreau's story of the pond and his life on its bank, and when he comes dripping from this and puts on the garments of everyday life he still must feel a little of the glow of the fire with which this alchemist of the woods transmuted all things, showing us how rough granite, hard iron and base lead are gold. Thoreau lived on the borders of the little clear pond but two years. He knew it in the flesh for just his short life. But his spirit had birth in something akin to its pure, profound waters and dwells above them now for all centuries.

The next plunge should be in the waters themselves, and only thus shall you learn to the full what a miracle the pond is. Here is a crater of 
glacier-crushed granite, out of which never came smoke nor lava, only a white fire from unexplored depths, a fire of cool austerity which burns the dross out of all that may be put into it. There is no inflowing stream. Its waters well up from a mysterious source within the very earth. Their outflow is equally invisible. In their going they leap spirit-like along the golden stairs which the sun lets down to them and pass up for the building of rainbows, their white light breaking in its mystical seven colors, a visible ecstasy to all who watch the heavens. To plunge in these waters at dawn is to feel this cool fire thrill through the marrow of your bones, and only by total immersion shall you know to the full its purity.

Coming to such a flight with Eos through the dusky solemnity of the trees of the western bank, I saw the pond silvered beneath its tense level with the frosty scintillations of the stars that had shone into it all night. It was as if their radiance had but penetrated the water-tension film of the surface and collected just beneath it, making a white mirror which my plunge shattered into a thou- 
sand prisms of scintillant light. The dancing night winds had shaken all the rich odors from the white clethra blooms that grow all about the pond's rim and stored them along its surface, and to swim out toward the center was to enter a sweetly perfumed bath. The forest to eastward, full of black density, as it was, could not bar out the rose of the morning from the sight. Instead it stood in a silhouetted fretting against it and let its glow shine through a million tiny windows of the day, blossoming again in the ripples ahead. Here was a moving picture of the blooming and vanishing of pink meadow-flowers, flashing a brief life upon the film, vanishing and growing again. The cinematograph is nothing new. Walden has operated it for those who will swim toward the dawn in its waters since the centuries began. In our theaters we are but tawdry imitators of its film productions.

Chin deep in its middle you begin to feel that you know the pond. In a sense you are its eye and look upon the world as it does. Day breaks for the swimmer as it does for Walden, and the flash of the sun above the wood to eastward warms 
you both with the same sudden sweep of its August fire. In the same sense you are the pond's ear and hear as it does. The morning rustle of the trees, shaking the dusk from their boughs, comes to you as a clear ecstasy, and you think you can hear the wan tinkling of the invisible feet of fairy mists as they leap sunward from the surface and vanish in the day. Over the wood comes the intermittent pulse of Concord waking, and by fainter reverberations the pond knows that Lincoln and more distant villages are astir. Then the first train of the day crashes by the southern margin and stuns the tympanum with a vast avalanche of uproar.

To plunge beneath the surface and escape this is to learn the real color of the pond. From without, on the banks, this varies. Oftenest it is a dull, clear green like that of alexandrite, a chrysoberyl gem from the mines of Ceylon and the Ural mountains. You see this best from the higher points of the hills along the borders and at certain angles of the sun the green shows red reflections and tints of blue as does the gem. If, swimming in the center, you will tip up as a duck 
does and go headforemost with open eyes into the depths, you will see none of this color. There with all the influences of reflection and refraction eliminated you find yourself moving through an infinitely soft blue that is semi-opaque merely because a million generations of use has fitted the human eye for seeing details through air only. Yet the perception of color remains. Hold your breath desperately and swim as far down as you may and there is no change. The color has all the softness and gentle beauty of the turquoise. In certain lights among the Florida Keys I have seen this sweetest, gentlest of blues in the Gulf Stream, but in no other water.

To turn and look at yourself in this water is to have another surprise. Already it seems as if the mystic fires of its depths had begun to inform you with a pure whiteness that should be akin to nobility of soul, and as you step forth on the shore mayhap this quality, passing subtly to the blood and brain, lingers for a while, and in the clear fire of renewed vitality you feel that the morning has indeed brought back to you the heroic age. 
To come to Walden at mid-day, even with Thoreau's account of it in the back of your head, is not at first to be impressed with the clear spirituality of its waters nor their depth. Here, you say, is the path from Concord, lightly worn by the spring of his tread, clumsily rutted by the heavy footsteps of many who follow, having indeed hitched their wagon to a star. Here is the cairn erected in his memory, to which with doffed hat you may well add a stone from the pond shore. And here is the pond itself, a gem of silvered water set among low, wooded hills. Your eye may well catch first a sight of the driftwood on the shore, of which there is much and think it makes the place untidy and wish that the Concord selectmen might have it removed. But the thought which this first mid-day glimpse stirs soon passes from you and standing on the very brink you realize the limpidity of the water and the spirit of dignity and peace which prevails over all. The world grows up around many shrines of its great ones and so changes the environment that you go away sorry that you came, wishing that you had let the place live in your imagination as it 
was in its heroic age, rather than as it has since degenerated.

Walden is Walden still, very much as Thoreau painted it. No chimney smoke rises in view from its shore. No picnic pavilion disturbs its outline or jangle of trolley echoes within its spaces. The woods grow tall all about it, and if they are more frequented by men than in his day and less by wild creatures the casual visitor need hardly know the difference. The pond was low when he wrote of Walden. So it is now and the same stones with which it was "walled-in" then pave the wide margins to-day. You may walk all around it on this crushed granite and note the sparkle of plentiful mica in the pebbles. Near the beach where he took his morning swim is the tiny meadow which in the years of high water is a cove to be fished in. You may throw a stone across this meadow cove and in any direction save at its narrow entrance from the pond you will hit tall woods that in dense array lean lovingly over it and give it cool shadows except when the sun is high. Between the tall trees and the meadow grasses grows the clethra, its white spikes of per- 


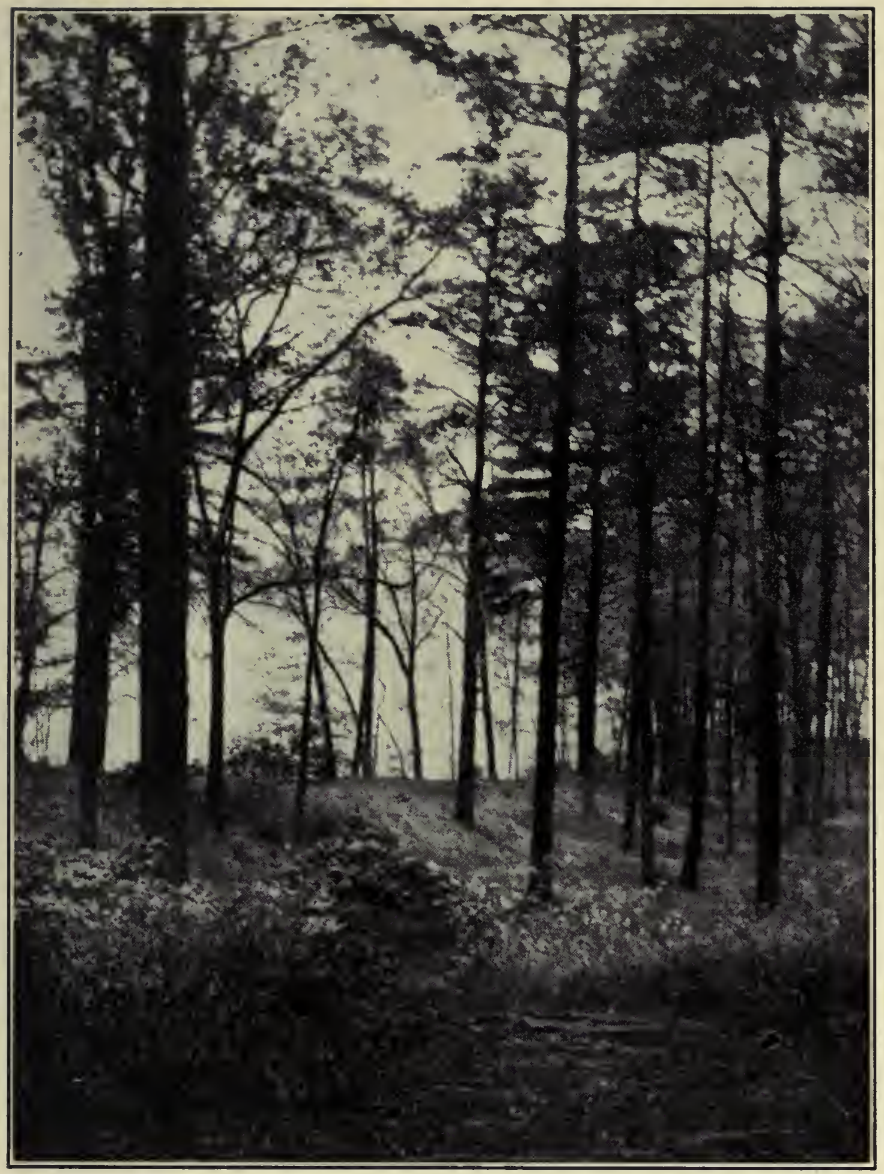

"Here is the cairn erected to his memory, to which with doffed hat you may well add a stone"

See page 65 

fume seeming to make a lace collar all about the place. In the bottom of this meadow grows much thoroughwort, which is a plain, homely weed to the passing glance, not considered fit for a garden nor thought to beautify a roadside as do so many fairer pasture blooms. Yet its gray-white heads add a soft friendliness to the coarse meadow grasses and give delicacy to the whole place, seeming to invite invasion and preparing the invader to find the more fragile flowers of the Gerardia tenuifolia that nestles beneath it, its pink bells set by some fairy bell-ringer of the dawn with mute throats open toward the sky. The little enclosure is as deep as a well, stoned in by forest walls, and is beloved of the argynnis butterflies whose spangled underwings shine with the same silver as the mica along the pond shore. Meadowsweet and a half dozen other August flowers warm their heads in the sun and cool their feet in the shadows of this same meadow, but the thoroughwort seems to possess it most and to have a feeling of rightful ownership as if it were Thoreau's own plant. All about the pond you will find it blossoming in the same way, standing bravely out from 
the wood with its feet among the close-set stones. Always before thoroughwort has seemed to me coarse and unattractive. Here it seems to belong and to give and take a certain beauty of virility and appropriateness. Perhaps it is because with it came so often the fond fragrance of the white alders and the soft, rose-pink beauty of the gerardia bells. In many places the stones of the beach are set so close together and have so little soil beneath them that nothing can grow, yet in others the plucky, bright-faced hedge hyssop has crept into the interstices among them and made a carpet pattern of soft green that is all flecked with the golden yellow of their blooms. And all behind these rise the woods, oak and chestnut, maple and scattered pines, whose plumed tops seem like the war-bonnets of Indian chiefs, standing guard over the homely, beautiful, simple, mysterious little pond which seems to excite love and reverence in the hearts of all who remain long on its banks.

The hills climb abruptly from the brink of Walden on all sides. The woods climb the hills and top their summits with half-century- 
old growth that yearly adds to its girth and stature.

Nor, one fancies, need these trees again fear the sweep of the woodchopper's axe. The spirit of reverence for its shores, which through the one-time hermit of Walden has spread to us all, should prevent that. For now the pond is much as Thoreau remembered it had been in his boyhood, walled in by dense forests, a place of echoes. Your spoken word comes back to you from this shore and from that, refined and made more sonorous, as if the wood gods would fain teach you oratory and had taken your phrase into their own mouths and put it forth again as an example. To your ears it comes again sweetened with the gentle essences of juniper, birch and sassafras, rich with the melodies taught to bare boughs by winter winds. In the haze of the August noon these other shores are distant to the eye. The sight must swim a long way through the quivering air to reach one or the other. The hearing, thanks to the kindly offices of the wood gods, leaps the space at a bound.

The'kingfisher seems as much a familiar of the 
place as the echoes. Like them he flies back and forth from shore to shore till you wonder whether he is trying to keep pace with them or whether he is the embodiment of one that does not need to be set going by a word but has volition of its own. The kingfisher's voice hardly seems to belong at Walden, it is so harsh and unlovely. Even in this very school of sweet echoes it has learned neither modulation nor singing quality. Far different is the gentle peet-weet of the sandpipers which precede you along shore in scalloped flight. Something of the bright sweetness of the hedge hyssop strolls along the moist stones of the margin with them, as if the two became yearly more and more related. Each fall I think the olive-fuscous backs of these little birds get just a little more of a golden tinge from this continual neighboring with the equally gentle, friendly Gratiola aurea. If in return some fine summer the hedge hyssop should blossom into twittering song no one need be terribly surprised.

In contrast to the fearless rattle of the kingfisher as he echoed from shore to shore and to the twittering, friendly sandpipers who ran so 


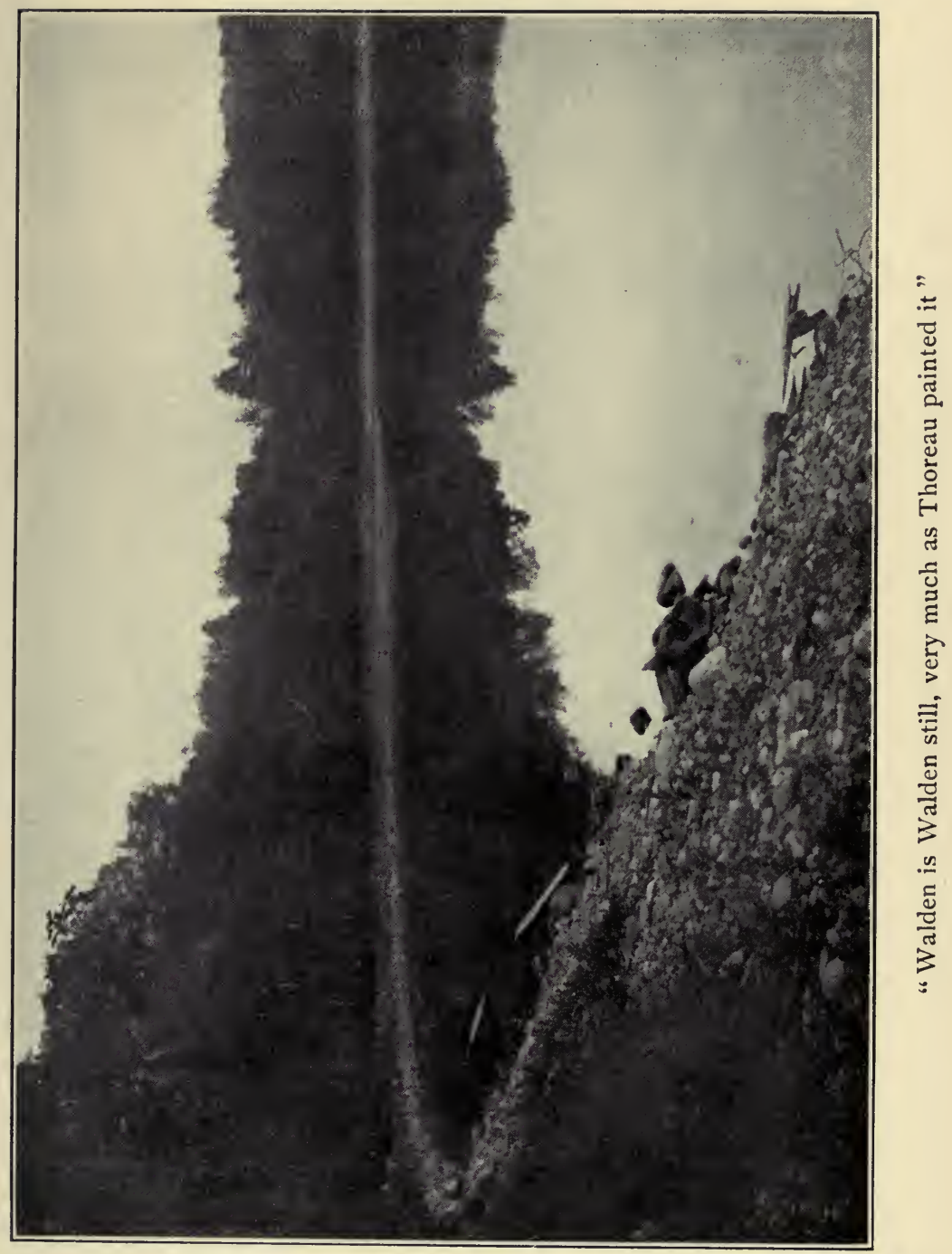



fearlessly along the margin, was the single little green heron that has made the pond his abiding place for a while. There is but one, nor are there any signs that herons have nested about the pond this year, so I fancy this bird is a bachelor visitor seeking to reduce living to its lowest terms and finding on the Walden shore the simplicity and seclusion that is the spirit of the place. $\mathrm{He}$ is as taciturn and patient as any hermit could be. When his country seat on one shore is invaded he simply flies silently to another and there resumes that inward contemplation which is as characteristic of the bird as the rattling, vibrating flight is of the kingfisher. The little green heron was a recluse of the pond shore long before the first pioneer planted his cabin in Concord. His kin still cling to the place which is as lovely and lonely now as it was then.

At nightfall deep peace settles upon the little pond. The shores that were so distant to the eye in the noonday haze draw in friendlily toward one another, and the last light slips through the trees to westward and throws a coverlet of shadow over this sleepy child of the woods. In the grow- 
ing dusk there is no mystery about the place. It is just a wee baby of a pond that is tired and has been put to bed. But as children often do when we think them asleep for the night the pond, as darkness gathered, seemed to dimple with wakeful laughter, to kick off the shadow quilt and dance with a new radiance of life. Gathering clouds of sultry August thunderstorms had gloomed the sky with the passing of the sun, and there was no star to give an answering twinkle, but the whole surface of the pond laughed up to the clouds in silvery light. It was as if all the mica-shine of all the granite ground together and sifted to make its unfathomed bottom had come to the surface, the infinitesimal flakes joining hands in a fairy dance to the tiny tune of the little evening winds. The pond was such a gentle little part of the vocal earth then that it did not seem as if it had ever been mysterious and informed with all the deep wisdom of the stars. Its surface was no bigger than the counterpane of a white crib on which danced the fairy dreams of the child that slumbered happily below.

Later someone lighted a fishing fire on the op- 
posite shore, and with a flash the mystery of the place returned. The cove where it burned seemed infinitely far withdrawn, and about it stalked shadowy giants who were the fishermen. Their voices, coming in brief sentences and at long intervals, were as weird as their shadows and as unsubstantial, from that immense distance to . which they seemed withdrawn. The whole was a mystery of the elder earth, as if man had fished here before the flood and came, a shade among the shadows, to try it again.

By and by the fishing fire ceased to flare and sank to a red glow of embers. The dense clouds, tempest-drawn toward distant skies, dropped southward. The moon rode out of them and all dignity and crystal beauty returned to the pond, no longer little but wide and deep and mysterious. Down the moon's radiance a spirit of fire strode, walking the water along a path of golden light, right into Thoreau's cove as I sat there on his shore. The pond was once again a well of crystal, now leading from the zenith to the nadir, and the white radiance of its spirit made mountain peaks of snow-white grandeur of the receding clouds. 
In the dark depths below these peaks flashed still the crimson scimitars of the lightning, but all about them and the pond shone a radiance of purity and serenity such as that in which we know Thoreau walked, day by day. 
ON THE FIRST TRAIL OF THE PILGRIMS

Present-Day Aspects of the Route of Myles Standish and his Scouts along the Tip of Cape Cod

Cape Cod reaches like a vast fishhook into the sea, the tip of the hook Race Point, Long Point the barb. It is as if the children of giants had come down to the coast to play and had modeled a hook in sand that Providence ordained should remain for all time, a sign for the nations. For here if anywhere has been notable fishing. On a November day in 1620 this hook caught and held for Massachusetts the expedition of the Pilgrims that had planned to sail for the mouth of Hudson River. Hence the epic which is William Bradford's account of the adventures of these argonauts is a New England epic. Had not the Cape caught and held them, who knows if there had been any story? 
The present-day pilgrim to Provincetown comes by the Mayflower route, in part, at least, if he come by sea, following in the wave-washed track of destiny. Like Gosnold's ship, like that which bore Captain John Smith, and like that greatest of all small vessels which carried Bradford and his friends, his ship glides by Race Point, coasts the long convexity of sand to and round Long Point, and heads northwest as if to go out to sea again, but is fairly caught by the barb of the hook, and landed. Between Boston Light and the tip of the Cape the voyager gets a taste of that same sea which Bradford and his friends breasted for two long months. If the sweet summer winds have been off shore for long enough there is little trouble, even for the landsman in this sea. It is likely to be smooth and smiling as an inland lake. If on the other hand the salt vigor of the east winds has shouldered it for a day or two the pilgrim of to-day may well hail the sight of the sand hills of the Cape with a joy as great and a hope of early relief as intense as did the lone voyagers of 1620 . Fish out of water that rolls like this bite eagerly at 
the hook of sand and are happy when they are landed.

The summer voyager of to-day finds this land which was so lone, this sea which was so bleak to the Pilgrims, teeming with humanity. The harbor waters sparkle within their rim of sand and toss innumerable boats on their- bright waves. Provincetown grows steadily between the sand hills and the sea and stretches daily nearer Long Point at one end of the curve and the North Truro line on the other. The town which began with a single little row of houses and the long slant of the beach for a street, is now miles long, has grown somewhat back among its sand hills, and is steadily topping some of them. The fishing-hamlet seaport of a half century ago is rapidly merging in the summer resort of to-day; is fast becoming a Pilgrim shrine also, whither come Mayflower descendants to comfortably worship their ancestors. So far as the old town goes little of its early quaintness remains, and that withdraws more closely within itself day by day. The hardy English fisherman and sailor stock that settled the Cape, such of it 
as remains, is smothered under Portuguese and summer boarders; not bad people these, but vastly different. The wind and the sea make minor changes in the Cape itself from year to year, especially this end of it. The waves give and the waves take away sand bars, now making an inlet where none was, now closing one that has existed perhaps for centuries. The winds pack the sands hard in drifts of rounded hills where once was a tiny valley, and again they come and take these away and establish them elsewhere as suits their vagrant fancy. Race Point, within the friendly shelter of whose barb the Mayflower fleet first cast anchor, is Race Point still, but I doubt if anyone can surely locate that pond on the margin of which the Pilgrim mothers did that first tremendous two months' wash. The caprice of the shifting sands may have whelmed and re-dug it a half dozen times since then. A century ago that little creek at what is now North Truro, that blocked the way of doughty Myles Standish and his men, sending them inland on a detour, was open still to the sea and a port of safety for the North Truro fishing boats. A half 


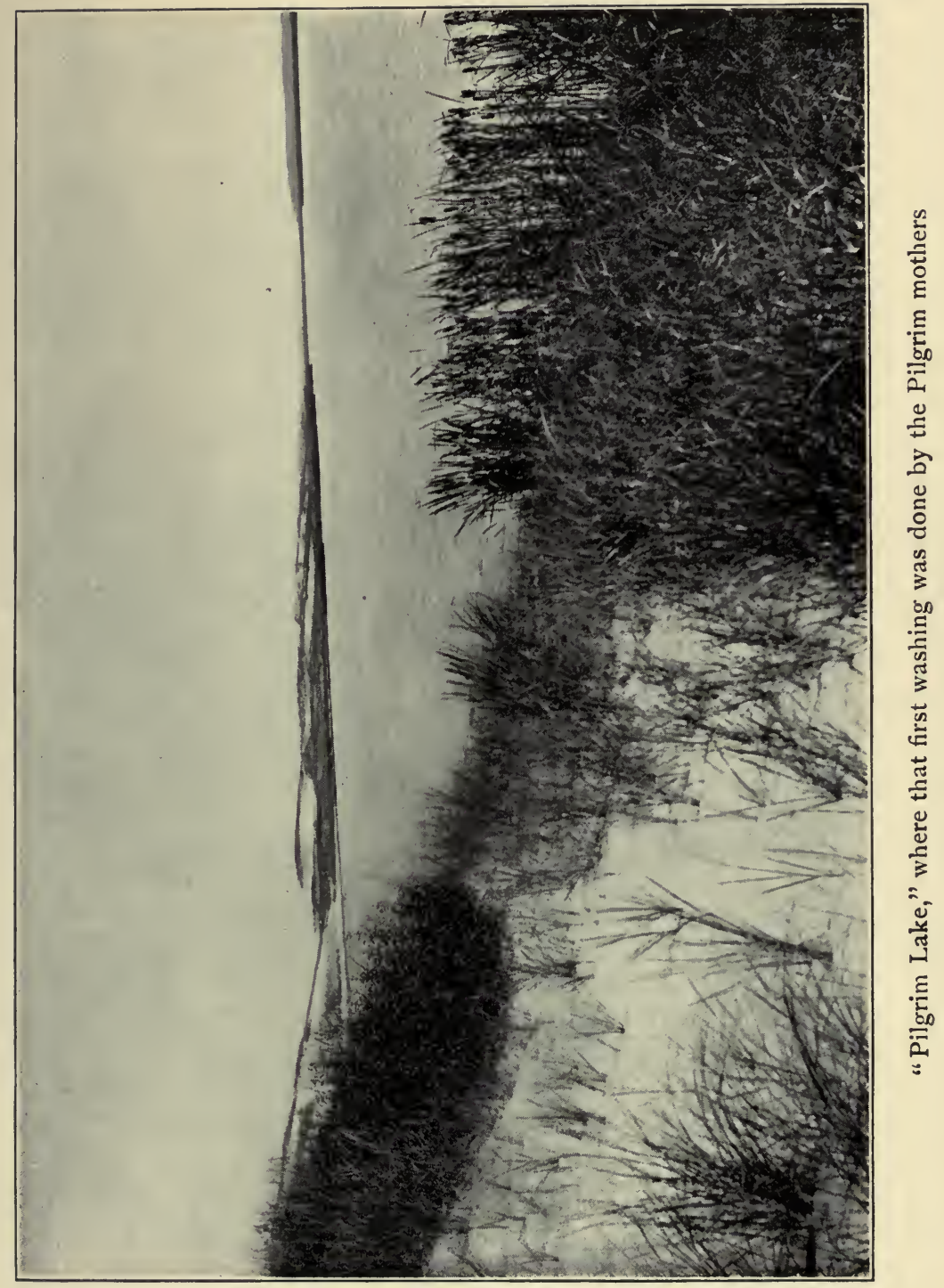





\section{ON FIRST TRAIL OF PILGRIMS}

century later a storm brought sand and so effectually closed this little harbor entrance that the North Truro fishermen have ever since launched their boats from the bare beach and the little inland sea thus enclosed has become a long, narrow, fresh-water pond, on which the Truro children skate in winter while their elders cut ice for the shipment of fish and the retention of summer visitors.

But after all it is only man's changes that make the tip of the Cape and its near-by narrowness different in our day from what it was when Myles and his men trod it with matchlocks ready and matches lighted, spying out the land. These as yet have not gone so deep but you may find portions that seem as wild and untrammeled now as they were then. Indeed they may well be identical. That a row of sand dunes has moved before the winds a half mile east or west matters little to the eye. They are sand dunes still, and the vegetation which grew up on them in one place or was wiped out, cut off by gnawing sand particles and blown away by the wind, or buried beyond all hope of resurrection in the over-riding 
drifts is the same to-day as it was three centuries ago. On this primal wildness of the Cape the march of human progress has in some measure encroached, but it is a long way from obliterating it yet. I fancy a man, choosing his route, could start at Race Point and go down the land by beach and by dune, to a point far beyond the one reached by the second, farthest, land-exploring expedition of the Pilgrim scouts from this point, without seeing more evidence of human settlement than the wheel tracks of a road deep in sand or a glimpse of the towering turrets of the Pilgrim monument which dominates the landscape for a long distance. Through this same length of Cape wind, of course, the hard ribbon of a State-built automobile road and the railway. But it is easy to lose and forget these.

In fact, you need but to climb sand hills and slide down sand declivities a very short distance north of the center of Provincetown itself to be as near lost as the Pilgrim scouts were and to find those dense thickets of thorny growth which they complained were like to tear their clothes and their very armor itself off their backs. No 


\section{ON FIRST TRAIL OF PILGRIMS 8I}

doubt the greenbrier was responsible for much of this wreckage of Pilgrim habiliments. Most varieties of this wild smilax, of which we have a dozen or so in this country, are to be found in more southern latitudes. But we grow here in eastern Massachusetts commonly the Smilax rotundifolia which climbs to tree tops, is as strong almost as cod line, and is well set with vigorous thorns. In the moist hollows among the sand dunes this vine finds good sustenance, puts forth most vigorous growth, and barricades gullies sometimes with an almost impenetrable entanglement of its thorny ropes. I have rarely seen a tropical tangle which is more impenetrable than one of these. It climbs and twines among beach plums and scrubby wild cherry shrubs, weaving all together in a dense matting. To Pilgrim warriors fresh from English fields or Dutch meadows this thorny wild tangle must have been embarrassing indeed. Even without the greenbrier the rich growth of blueberries, high and low blackberry, wild rose, bayberry and sweetfern may well have sorely tangled and tripped their unaccustomed feet. 
All these are growths of the bottom lands, the hollows among the sand dunes back of the town. Within some of these are little fresh ponds in which grow waterlilies and the usual aquatic plants of such places. Here amid the prevailing wildness are many little beauty spots which, could the Pilgrims have come to them before the winter frosts had wrecked the vegetation, might have tempted them to stay. Passing on down the Cape you soon leave these behind and get into the higher dunes on the narrowest part where vegetation has little chance for its life. Here for a mile or two one might well think himself in Sahara. The sands, blown hither and thither and piled in fantastic shapes by the winds, are as clean as those of the beaten sea beach, as free from all suspicion of humus.

Yet if you will cross Sahara in most any direction to the camel's-hump hills which are scattered over its border as if a caravan had become petrified there, you will find the humps sprouting vegetation, a vegetation that is sparse, perhaps, but to your astonishment is glossy and luxuriant of leaf. More than one of these mounds rep- 
resents a drawn battle between whelming sands, wind-driven, and a vigorous wild cherry tree. How such a tree finds its start in these shifting, scouring sands is a puzzle. Yet once started it is easy to follow with more or less accuracy the course of the war which lasts years. The winds take the young shoot for a nucleus and pile their sands all up about it, yet may not quite cover the very tip, for there the varying draft whirls the topmost sands away again. The sand really helps. It mulches the young plant and protects it from the winter cold and the gales, from the summer heat and the drought. Each year the thus protected plant grows joyously more straight shoots, to be whelmed again almost to the tips by the sand, and so the merry war goes on till finally we have a dune twenty-five or thirty feet high, with the trunk and larger branches of a wild cherry tree for a core, its smooth, hard-packed surface wreathed with green leaves and often bearing rich, dark fruit for the delectation of all who pass.

These brief, hill-top oases do not relieve the desert-like wildness of this narrowest part of the 
Cape, however; they merely serve to accentuate it. From them you see the vasty blue velvet of the ocean outside the Cape and think it but a brief plunge to it through the glittering sands. Yet as you go toward it you find that one sand ridge hides another and that the valleys between hide brackish meadows in which grow strange plants, fleshy of stem and stubby and thick of leaf, as if they were degenerate offspring of land plants that had most unhappily intermarried with sea weed. On the margins of these witch pools it is a pleasure to find growing good old sturdy homely dusty-miller. Whatever broomstick-riding hags infest these weird hollows of windy midnights, here stands that plain common-sense Puritan to shame their reveries. Cineraria maritima may not have come in the Mayflower, but some ship from England brought him and he is a Puritan without doubt. If the witches do gather in these wild hollows of Cape Cod's desert I warrant you he gets after them with a tithing rod and drives them back abashed to their own chimney corners.

Passing the desert you find the Cape widening 
again and growing green with vegetation. Yet something of the witch impress is on it still. In the distance you see forests of pitch pine which as you approach show branching trees of seemingly luxuriant growth. As you stride up to these trees you find them shrinking in stature while yet keeping their proportions and luxuriance, and finally you march, a modern Gulliver, through this Liliputian forest that may not reach higher than your shoulder. Here was a Pilgrim's progress for Myles and his men that may well have added an eerie touch to their expectation of wild men of the woods. Such a forest - and I have no reason to believe the North Truro forests have changed much in just three hundred years - might well produce trolls or giants, as well as Indians. I can fancy the mail-clad explorers glancing at the glades of these enchanted woods with a bit of superstition. in their apprehensions, saying prayers out of one side of their mouths and charms against evil spirits out of the other. Nor can one blame them, thinking what these hills are in dreary November weather, with snow squalls hiding the sun and the wind 
complaining among these loneliest of forest trees.

In late summer it is different. Out of the gray reindeer moss and poverty weed which are more prevalent than grass on the sands beneath these trees spire slender scapes of Spiranthes gracilis, the tiny orchid that someone named ladies' tresses, not because the flower looks like them but reminds of them, being wayward and fragrant and lovingly blown by all winds. Here is goldenrod, and wee asters are just opening their baby-blue eyes to the approaching autumn. Wood warblers trill in the absurd forest, and the rich aroma of its leaves subtends the lighter fragrance of the blossoming wild flowers. In feathery glades among these Truro trees one might forget that winter is to come and bring bleakness and desolation unspeakable to the land with him. But if winter does not always warn, the sea does. Not so deep in any witch hollow can you hide, not so far may you wander in enchanted forests, as to escape its call. The trees murmur continually the song of the surf, and the crash of its breakers echoes continually in the air 


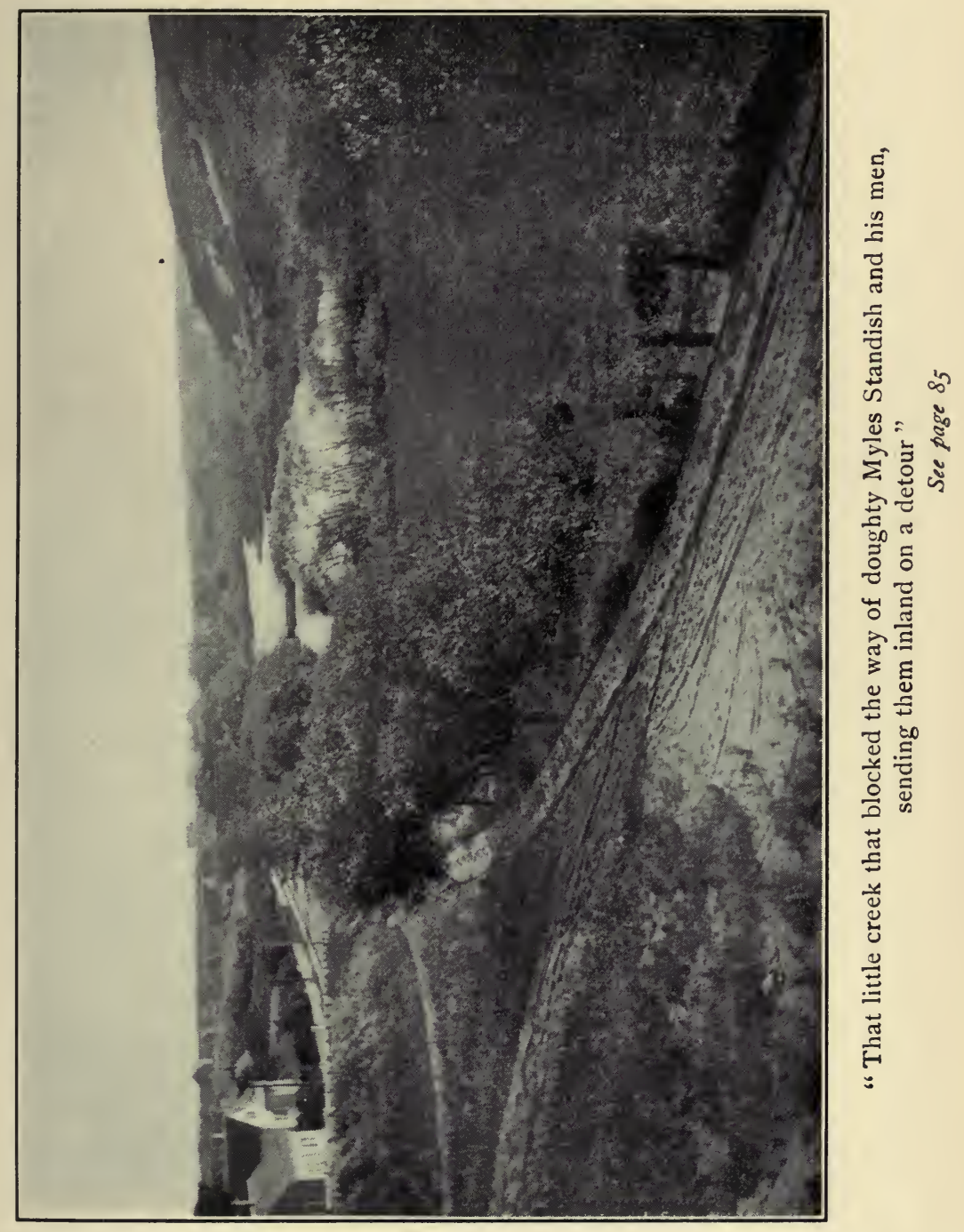



overhead. The wind song in the trees is not menacing, it is simply a minor melody, full of melancholy, as if it knew sad things and could but let them tinge its music. But even on quiet days when the south wind drifts gently in over the bay there sounds from the air above these mellow glades the growl of white-faced breakers that are never still on the northern shore. Out of the northeast they roll over gray-green leagues of cold sea, and as they bite deep into the sand of the shore behind Peaked Hill Bar, and drag it and all that is on it down into their maw and hurl it all back again, beating it on the beach and snatching it and beating it again, it roars inarticulate threats that make the onlooker draw back glad of a space of summer-dried sand between him and its depths. If this threatening undertone lingers in the ear even on a summer day with the wind warm and fragrant from the south, how must it have sounded to the Pilgrim explorers in a November northeaster?

And yet, for all the November bleakness to come, for all the ever-warning growl of the sea, I wonder, had the Pilgrims arrived at Province- 
town in late August, if they would not have stayed. Nowhere in New England would they have found the late summer huckleberries sweeter or more plentiful, nowhere the beach plums rounder or more prolific. Here was to be gathered in handfuls bayberry wax for their candles, and its aromatic incense floats over the Provincetown hills to-day as rich and enticing as then. There is little hope of fertility in the sand banks, to be sure, yet in the cosy hollows between these the homesteaders of to-day plant corn and beans, pumpkins and peas, and their gardens seem as luxuriant and productive as any that one might find in Plymouth County. The native trees of the place seem dwarfed, as I have said. But in the town itself are willows and silver-leafed poplars, planted by later pilgrims, which have reached great size, a willow in particular in the older part of the town being at least five feet - I would readily believe it is six - in diameter. There must be fertility somewhere to grow an immigrant to such girth.

Here too, rioting through the old-time flower gardens and out of them, dancing and gossiping 


\section{ON FIRST TRAIL OF PILGRIMS 89}

by the roadside and in the field, sending rich perfume across lots as a dare to us all, is BouncingBet. I cannot think of this amorous, buxom beauty as having been allowed to come with a shipload of serious, praying Pilgrims or any later expedition of stern-visaged Puritans. I believe she was a stow-away and when she did reach New England danced blithely across the gang plank and took up her abode wherever she saw fit. Thus she does to-day. All over the Cape she strays, a common roadside weed and a beauty of the gardens at once. Out of this point where the Pilgrim epic first touches our shores she comes, with the memory of the visitor, a welcome garnish to the long sandy trail once trod by Myles Standish and his armor-clad scouts. 


\section{VII}

\section{IN OLD CONCORD}

The Unspoiled Haunts of Emerson, Hawthorne and Thorean

One may seek in vain in Concord the reason for Concord. "It is an odd jealousy," says Emerson, "but the poet finds himself not near enough to his object. The pine tree, the river, the bank of flowers before him, does not seem to be nature. Nature is still elsewhere. This or this is but outskirt and far-off reflection and echo of the triumph that has passed by, and is now in its glancing splendor and heyday, perchance in the neighboring fields, or if you stand in the field, then in the adjacent wood."

With this same odd jealousy one may tramp the fields and woods, the pleasant highways and the village green to-day and not quite find Concord, for the Concord that one's mind presaged has passed on. This is but far-off reflection and echo of the triumph. Fuit Ilium. Yet here is 
all that first gave the name to the town, and more. Here are peaceful rivers meeting in rich meadows from which spring with the rising ground fruitful fields. Here men dwell in amity and keep singularly intact the beauty and thrift of a New England village of a century ago, though even here one can see wealth taking the place of prosperity and the pretentious ugliness of the modern attempt at Queen Anne architecture shouldering the quiet dignity of the old Colonial residences off the street. Here and there a little of the husk of the Concord of the Revolution remains, though somewhat sadly hemmed in. A simulacrum of the Concord Bridge still spans the flood, done in resonant cement, but here the poet finds himself not near enough to his object. Nor is his jealousy an odd one, for the rude bridge that arched the flood led somewhere. This echo of the triumph that has passed by drops him who would tread in the footsteps of heroes within the narrow bounds of an iron picket fence beyond which keep-off-thegrass signs doubly defend the way. In the presence of these the Minute Man seems superfluous. 
The British never would have got by this. Fortunately it is easy to believe that the Minute Man has never seen the barricade or the signs. In him at least Concord, the Concord of the Revolution, holding in its calm heart sons born of the soil and sturdy with its grit, is personified for all men for all time. To turn one's back upon the fence as he does and look across the grassy Musketaquid vigilantly at those swaying lines of British bayonets is to dwell for a little in the Concord which, with a streak of yellow flame and a whizzing bullet, first leapt skyrocket-like into the world's eye. Many things have made the beautiful village a Mecca whither journey pilgrims from all over the world. All come eager to look upon the spot where the farmers marched deliberately upon the king's troops and dared fling back into their faces the red gauntlet of murder. It is not to be believed that curiosity merely is the spirit which informs these pilgrims. One can but feel that they come to the bridge in reverence for the principles involved in the fray, and in looking upon the very spot hope to learn what went into the making of the men who so 


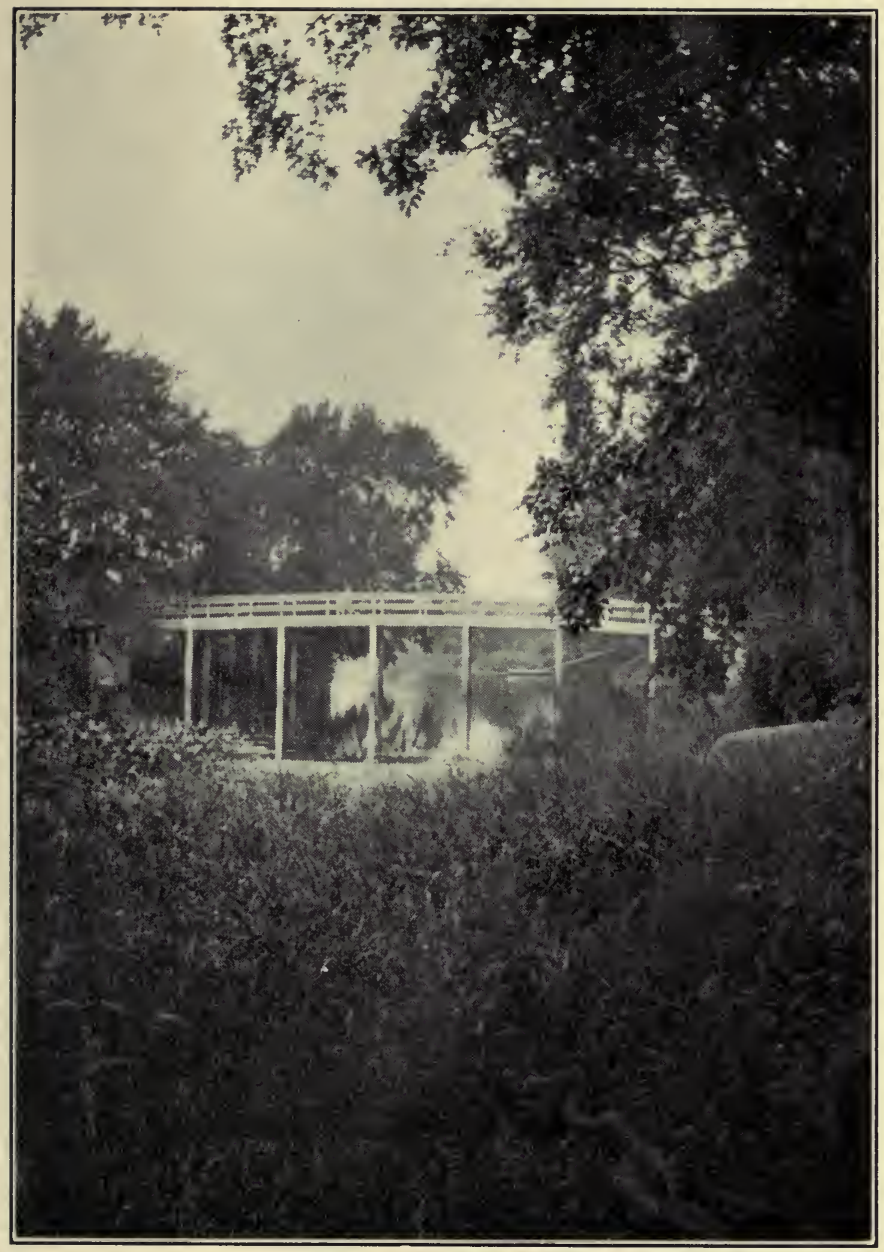

"Here in a volley was the summing up of the nature of the heroes that had grown up, quite literally, in the Concord soil" 

boldly hazarded life and worldly comfort and prosperity in the defense of these principles.

For, after all, it was the men behind the principles that counted. Here in a volley was the summing up of the nature of the heroes that had grown up, quite literally, in the Concord soil. Did they come of the fertility within it? One must say yes, in part. Down stream a little, not far below the bridge, I found an old-time path of their day, now long since disused, along which in the rich bottom land the meadow thistles grew ten feet tall. Such virility the Concord soil no doubt gave to the heroes who ceased delving in it only to grasp their muskets for the fray. The Minute Man holds to his plow still, the sculptor justly thus carving him. Out of the good brown earth one can easily know that courage and selfreliance thrilled through share and beam and handle into the bone of the man himself. Till the earth is fluid such men do not run. Like it they stand firm. Yet here is but the bony structure of the man in the Concord fight. Something more must go in to the making of a hero. It has been justly said that at the narrow bridge stood 
men born in direct descent from heroes of a stubborn stand, a stricken field, of seven hundred years before, and I dare say it is true. Planted among the Concord meadows and fertile uplands, grown lusty upon the richness of her soil, were men of Kent, that sturdiest county in all England; men whose very forbears had stood with Harold behind the wattled fence at Hastings, and died there with Norman arrows, in their necks. More than all else in the building of men blood counts.

Yet, tramping the highways and fields of the old town, dreaming within her woodlands and by her ponds and streams, it pleases me to think there is more to it even than this. In Plymouth woods grows the mayflower, as we love to call it, the trailing arbutus, filling the spaces with rich scent in late April and early May, and though it is eagerly sought by thousands and is sold in bunches on all city streets in spring, yet it is not rooted out but retains its hold on the soil there. In certain other eastern Massachusetts towns the trailing arbutus never grew, and though I know of many attempts to transplant it to these 
none have succeeded beyond a slight growth that is hardly lusty or likely long to survive. Y'et among the Maine and New Hampshire hills again the mayflower grows luxuriantly. So it is with the hepatica and the maidenhair fern. Some cool northern hillsides are beautiful with these, others with equal shade, cool springs, moss and gravel have never known these plants. No. More is necessary than that the blood of men should fall and take root in fertile soil. There must be fluid, where seed and fertility meet, some of that ichor which flows in the veins of the immortals, and it must enter into the growth. Only thus does Hodge become hero. Without it he holds both hands on the plow and lets the British pass the bridge and go on. How many nations have thus been stillborn and buried in the furrow no history can tell us!

Little by little nature gives us the secrets of these things, as when after a time she taught the Australian planters why clover would not produce seed there. It grew well in fertile soil when seed was brought from England; it blossomed and made good fodder for cattle, but never a 
seed. Then they imported bumblebees from the English meadows with probosces long enough to reach the nectar in the bottom of the clover blooms and thus be pollen carriers from plant to plant. Here was the solution of the problem, the ichor of immortality that the clover needed. So with alfalfa and most leguminous plants. Scientific investigation has shown that if seeds of these are to grow well and thrive in new regions distant from that of their cultivation more is needed than the right soil and climate. Certain mysterious bacteria are present on the roots of all plants of this genus, and in some obscure way take from the soil and give to the plants the elements of vigor and success. Now the scientific horticulturist steeps his seeds of alfalfa or other leguminous plants in a culture of these bacteria, and knows that if his planting is in fertile ground and the sun and rain do their work well his harvest will be bountiful. Here again is the ichor of the gods, Vishnu become fluid and incarnating himself in obscure bacteria for the building of the plant world.

So, I can but fancy, has it been with Concord 


\section{IN OLD CONCORD}

and her men. The seed of the Kentish heroes of Harold's time has grown since in many soils. In Concord when time was ripe it found fluid there some of the ichor of the immortals coursing through farming tools to the making of fire for heroic deeds. The Concord fight did not happen; it had to be. It was not that every Concord farmer's barn was full of munitions of war. Every Concord farmer's blood was full of powder. The shot had to be fired there.

For nearly three-quarters of a century this mysterious essence of greatness that one feels must always be present in places where great deeds have taken place seems to have flashed no spark to the outer world. Grass waved on Concord farms and fell before the scythe, and new generations of farmers grew up to take the places of those which passed unmarked outside their community. For that space of time Concord was, very much as Troy was, the scene of a memorable fight. Then came Emerson to bring back to the place something of the nobility of spirit and independence of thought and action that must have come to it with his ancestor the Rev. Peter Bulke- 
ley. Here was the scholar and the preacher instead of the farmer, but born of the same old sturdy stock and come back to set roots in Concord soil. Here he walked daily in the fields and woods with his veins open to that same ichor of the gods which had not made patriots and heroes indeed, but had given them tongues, which seems to have given power of expression to him who was already poet and seer. Here with him, grown up out of the same town, was Thoreau. Hither came Alcott to paint the bubbles of his inchoate dreams in rainbow conversation. Hither too came Hawthorne, to tramp the woods as did the others and feel as did they the divine afflatus drumming in their veins and the impulse to sturdy independence coming up to them out of the Concord soil as it thrilled up to the Minute Man through his plow handle. It was not so much that these men had within them the poetic fire, but that it burned there on the hearth of freedom, independence, and intense individuality.

With them Concord came again into the eye of the world, and because they preached as well as wrought, the world's eye is still upon it. And, 


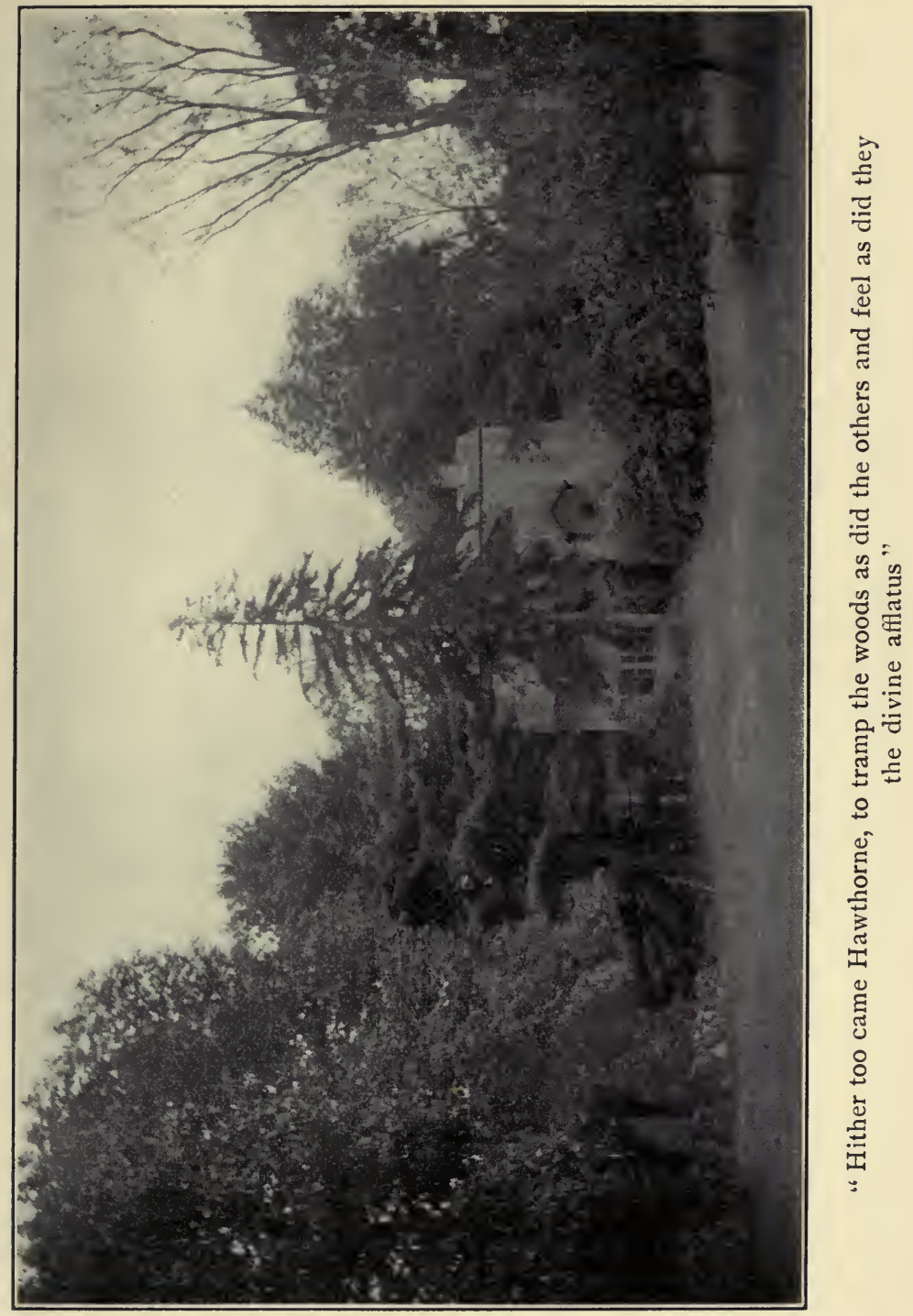



as after the Minute Man and his times passed the little village slumbered, seeming to wait placidly for the next troubling of the waters, so now Sleepy Hollow, where these four dreamers lie, seems to be the real center of the town. The mystic dreams of Hawthorne, the golden serenity of Emerson, the primal wisdom of Thoreau, and the roseate fog of Alcott's transcendentalism all flow serenely forth over its rim and flood the green hills and shadowy valleys of the region with peace and sweet content. Here, almost side by side, rest the four, and such blood of the gods as flowed in them is piped to all the world by way of what each wrote. No wonder Concord is a place of pilgrimage and people come by thousands to these graves as devout Mohammedans go to that of the prophet. Red oaks set their roots deep in the knoll where these lie, and white pines tower above them as if forming the first and most fitting round in their ladder to the stars. Out of the tops of these pines the harper wind should pluck harmonies beyond those common to groves.

Hither come the pilgrims that have hastily 
viewed the Minute Man and the bridge, puffing in rows up the hillside and standing, breathless but voluble, before the stone they have sought. Reverence in their hearts they have without doubt, yet little of it gets to the surface as they, panting, recite one to another the legend of the stone and pass on. It is a wonderful piece of white quartz that marks Emerson's grave. There is dignity in its roughness, and something of the pure opacity of Emerson's thought seems to dwell in its white crystals, fittingly touched here and there with a color which might be the matrix of all gems. One thinks from what he sees of those who pass that Emerson is best known, Hawthorne most loved, while Thoreau and the Alcotts have each their own special worshipers. Now and then one sees much reverence based upon a rather slender knowledge, as when a young man balancing a year-old baby on his arm said to his wife, "This, my dear, is the grave of Thorough, David Thorough, the man who wrote 'Zounds.'" One can fancy David, who was Henry to most of us, being willing to be called thorough, yet hesitating to acknowledge " Zounds," except perhaps 
as an exclamation of astonishment. As an offset for this I might cite the small boy who, having been shown the stone which marks the grave of Louisa Alcott, gave it shyly a little loving hug and a pat before he went away. In the highest group of Concord immortals it is not customary to include the talented daughter of the transcendentalist, yet of the worshipers who pass not a few lay their fondest offering on the turf that covers her.

For a few hours out of the twenty-four, visitors to Sleepy Hollow come and go. Except for that the hollow indeed sleeps, steeped in the gentle peace of all nature which seems to well up out of it and encompass all the region round about in its golden haze. Surely the lotos grows where the Assabet and the Sudbury join to make the Concord, that sleeps on so gently that one may hardly know that it is on its way. The lotos grows there and the land has eaten of it, for the bustle of the world passes over it but does not change nor wake it. The very farms of Revolutionary time linger on, and if they are tilled now as they were then I do not know, but the 
cattle graze on the hills in herds as great now as then, and as broad cornfields toss their golden plumes toward the sky. The houses where dwelt Emerson, Hawthorne, the Alcotts, still stand, and into the fields round about them few others have crowded. The fertile soil still yields crops to the husbandman, in whose breast slumbers mayhap the same sturdy courage which made the Minute Men and would make others should the need arise. Manufacturing, summer hotel keeping, these things do not seem to have touched the town much. I fancy it as lying fallow, waiting the flow of that ichor of the immortals that shall some day again waken it to great things.

"The Sphinx is drowsy,

Her wings are furled;

Her ear is heavy,

She broods on the world,

Who 'll tell me my secret,

The ages have kept?

I awaited the seer

While they slumbered and slept.

"The fate of the man-child,

The meaning of man;

Known fruit of the unknown;

Dædalian plan; 


\section{IN OLD CONCORD}

Out of sleeping a waking;

Out of waking a sleep;

Life death overtaking;

Deep underneath deep."

Thus we find Concord to-day an historical and literary Mecca, a fine example of what has always been best in a New England town, holding firmly to the old, choosing, one believes, the best in the new, brooding the past in dreamy persistency, biding its time for the good that the future is to bring. Some day out of its lush meadows and the rich mold of its hillsides will flow again into the veins of men that subtle fluid of flame that makes heroes and poets. It is for this the fine old town lies fallow, and in this shall be the justification for its patience. 


\section{VIII}

\section{"THE OLD OAKEN BUCKET"}

Its Home in an Unspoiled Corner of Pilgrim Land

It is not often that the scenes of a man's childhood remain measurably intact when that childhood occurred something over a century ago. Yet that is the case with Samuel Woodworth, whose detached name I fancy not one man in a thousand would recall, even among wellread people. Yet you have but to mention "The Old Oaken Bucket" and you get an answering smile of recognition from the veriest ignoramus. Even if he cannot recall the words he can whistle the tune.

People given to moralizing are apt to take instances like this for a topic and wind up with the familiar aphorism, "Such is fame!" And such it seems to be, rightfully enough I dare say. Here was a man of journalistic training and 
literary instincts who must have figured fairly large in the New York journalistic world of his day. He wrote novels, plays, operas and a vast amount of miscellaneous matter. He founded one journal after another, among these the New York Mirror, yet the world recalls him only by way of the little song, sweated out of him by the heat of an August day in New York. Those things that the poets "dash off" at one sitting are usually, rightfully, the cause of editorial derision. Now and then, it seems, something is wrung out of a man's heart at a single twist that taps the deep springs of immortality.

Governor Bradford, writing of Plymouth Colony, early regretted that his Pilgrims were little content to stay within easy reach of Plymouth Rock but remained Pilgrims still, migrating through the woods and along shore to seek new and better farms. This was but the further expression of that wanderlust which had brought so many of the followers of the Pilgrims over seas. The spirit of adventure manned many a ship that followed the Mayflower to Massachusetts Bay, and the descendants of these adven- 
turous migrants have since explored and settled the country to the very tip of Alaska.

One of the first of these early impulses to move on took Pilgrims to Scituate, and here in r636 an ancestor of Woodworth dug and stoned a well, thirty-six feet deep, in that little corner of the present town now known as Greenbush. The Pilgrim settlers and farmers marked their trails behind them with stones that stand as their most lasting physical memorial to this day. One can but fancy that the glaciers which built the land the Pilgrims were to occupy, grinding, mixing, sifting soil from a thousand miles of back country and dropping it in southeastern Massachusetts, moved on ball-bearings, so numerous are the rounded boulders they dropped behind them in this fertile mixture. The stronger and richer the soil the more of these boulders are to be found in it, and the Pilgrim farmers had a double task in the clearing of their farms. They must not only fell the trees and remove the stumps, but they must go deeper and get out the rocks before their plows could furrow it. How well they set their stubborn wills to the grubbing of these rocks we know 
as we look upon their fields, to this day bound in neat parallelograms of gray granite, each round stone set upon two others, as the Pilgrims taught their sons to place them, little disturbed by stormy centuries that have merely served to garland them with ivy, clematis and woodbine.

Wild things of the woods have come to know and love these old stone walls. Chipmunks, woodchucks, foxes even, find refuge and make their homes in the artificial galleries thus enduringly placed, and the wild flowers of the field snuggle up to them to escape the farmer's scythe, paying for their shelter in beauty and fragrance. Close to the walls, however well shorn the field, the winds of this first day of October toss yellow curls of goldenrod blooms, while the asters, children of the year's late prime, open wide, roguish blue eyes among them. Particularly do these wayside children love to ramble along one of the old stonewalled lanes leading from the pasture to the cow barn, as if they came up with the cows night after night, and lingered outside only because the barn is closed on them before they managed to loiter in. 
"The cot of my father, the dairy house nigh it, And e'en the rude bucket that hung in the well"

are gone, but the old barn still stands in its wonted place and to it come the cattle by the same old lane, the cattle lane that has been such since that pioneer set the gray stones as a fence on either side of it nearly three hundred years ago. Up and down this lane the farm boys of one generation after another have whistled and dreamed dreams while the cattle went quickly forth to pasture in the morning or loitered back at milking time, nor hardly has one stone slipped from another in the passing of the centuries. Yet they have been there a long time, those stones, the gray lichens have grown black on their sides and they long ago seem to have settled together with an air of finality A newly built stone wall does not look like this. It is an excrescence, an artificial boundary. These, stone walls are nothing like that. They look as if the glacier had intended that they should rest there, a part of the rock-ribbed arrangement of the earth as it left it. So with all these gray stone walls that bound the farm and the road. They long ago lost the air of having been put in 
place by man and have lapsed into the primeval arrangement of valleys and moraines, a logical result of first causes. There is a restful, old-home feeling about the old barn and this old lane, and it is no wonder the wild flowers that have strolled into it love to remain.

All September it has been golden with the velvety yellow blooms of the fall dandelion, a milky way of yellow stars that twinkled as the wee winds slip through the pasture bars and wander down the lane. Now, with October at hand, they pale a little at the thought of coming winter, as the stars do at the approach of dawn, and here and there is one that is shivering into white pappus, ready to vanish, ghost like, down the wind. But these are but few; most of them hold their gold bravely toward the sun still and valiantly deny that there is anything to be afraid of. The grass is as green and velvety there as in spring, but the other denizens of this lane know that winter is coming and show it. The cinnamon and royal ferns that have come up from the meadow in times past and now snuggle their roots down between the very stones of the foundation of the wall, 
know it, for they have paled to a wan, tan brown, as delicately beautiful as you shall find on any autumn-tinted tree of the forest. The woodbine is a deep, rich red, and the poison ivy that helps it garland the old walls has ripened its leaves to the loveliest apple reds and yellows that can be found. There are sweeter-natured things than this poison ivy which beautifies old walls and fences at this time of year, but nothing that gives us quite such softly delectable tints of ripeness. It seems as if these ought to tempt us from the cheek of some rarely palatable fruit rather than the poisonous leaf of this vixenish vine.

"The wide-spreading pond and the mill that stood by it" have long since done their work and the mill of Woodworth's day has passed. Yet the pond remains in all respects as he knew it, the deep tangled wildwood lining its one shore, the roád and a fringe of houses skirting the other, and below it another mill, long since fallen into disuse and decay, for the one that Woodworth recalled was a product of the century before the last one. Over the stones of the old dam the water trickles down and meets the salt tides of the sea, and here 
at a step the boy of more than a century ago passed from one country of romance to another. Up stream lie to-day as they did then the rolling billows of land, fertile fields, wooded hills and the tangle of swamp and thicket that is, I believe, more luxuriant in those parts of Plymouth County where the forest comes down to the sea than in any other place. I have never found, in tropical jungle or the warmer countries of the temperate zone, such matted areas of richly growing shrub and vine as you meet in these Plymouth County bottom lands where the fresh water comes down to meet the salt. Fox grapes luxuriate there and woodbine and convolvulus climb and twine, but the toughest of the tangle is due to the greenbrier, to penetrate which one needs to use a machete as much as ever Cuban did in Camaguay. The greenbrier is tough and its thorns repellent, yet its glossy smilax leaves are beautifully decorative and its close-set bunches of deep blue fruit, now ripe, please the eye if not the palate. Thickets like these border the pasture paths in this rich bottom land walling in the wanderer with high tapestried walls of vivid green, richly patterned with varied leaves and 
flowers the long summer through. Somewhere there may be a more beautiful country than such pasture land. Wandering far I have failed to find it.

When the east wind blows in on this lovely country of pasture, field and woodland it brings the roar of the sea and the smell of it. The breakers that smash against the boulder-strewn base of Third Cliff send the call of the wide spaces of the earth into the secluded glades, and match the lure of their odors against the fragrance of the woods. And here between the two lies the level stretch of the salt marsh, the noman's land, the Tom Tiddler's ground, which the sea may seize but never quite possess, which the country may invade but never overrun. The marsh is a little border world of itself, with its own plants, its own birds, even its own air. It infuses into the cool rich breath of the sea a tonic fragrance of its own, and there is a rich harmony in the coloring of its wide levels that more than matches any beauty that the land or the sea has to give. Colors drawn from the weeds of the deep sea caves and the clear depths of cool brine, olives 
and browns and greens, keen grays and soft blues, are in the marsh, shaded and toned to an individuality of their own, as tonic to the eye as its ozonic odors are to the sense of smell.

Through these comes the full tide twice a day, bringing the salt, cool tang of its kisses to the feet of the old dam, there to meet those of the stream brought far from cool springs in the hills and daily perfumed with the petals of some newly ripened wild flower, caltha in the spring, wild rose in the summer, clematis now, with aster and witch hazel still to come. No wonder "the wide-spreading pond and the mill that stood by it; the bridge and the rock where the cataract fell," were strongly fixed on the memory of one who had in boyhood been familiar with these scenes. The farm of his ancestors may not have held these by deed, nor the level wonder of the marsh, and the blue reaches of the sea beyond, but it held them, nevertheless, and the man that owned the one had an inalienable right to the other. Nor need the passer in this unspoiled, half-forgotten corner of Pilgrim land be without them, though he merely rent a room by 
the day or come with staff and scrip for but an afternoon.

It was about these, too, that "The Old Oaken Bucket" was written, though the words of the poem do not say so, nor, I fancy, did the author realize it. The water from the old well cooled the throat of his memory with these and sparkled with them to the eye of it as he recalled the dripping bucket. Without the background there were no picture, however we forget it in the vivid figures in the foreground. The background of Woodworth's picture remains much as he left it when, a boy in his teens, he started for Boston to make the fortune he was later to find in New York. Of the figures he painted in the immediate foreground, some remain vivid still, after the lapse of a century. It is not so with the orchard. The great trees that still bear good fruit that they toss over into the lane up by the old barn are vigorous in an old age that might well seem to go back and include the beginning of the nineteenth century, but it does not. The trees were planted since the poet's day. One tree only of the orchard he knew remains. That stands just within the wall at the 


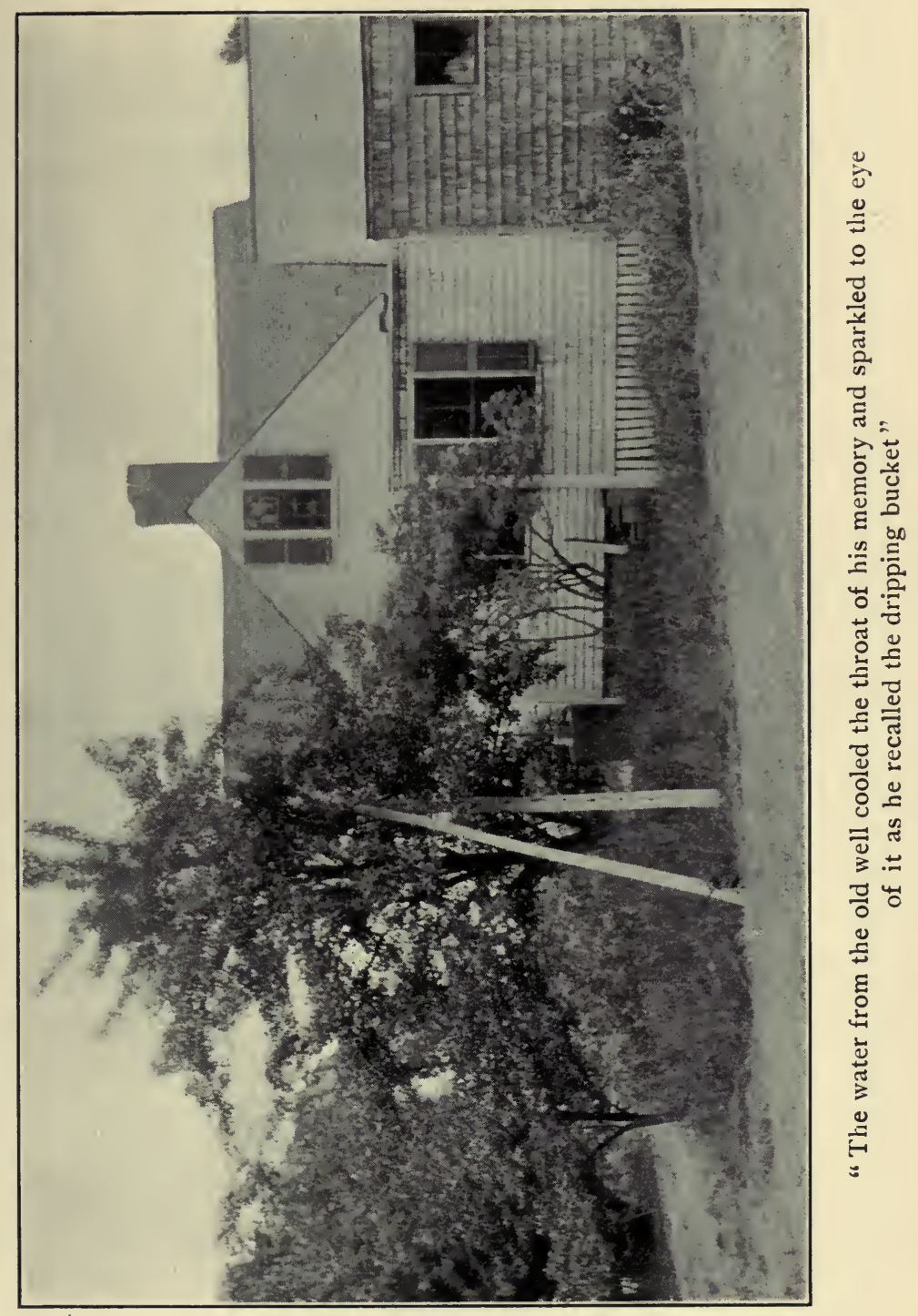



road, a stone's toss from the well, bearing on its topmost growth old-fashioned russets. But this tree was top-grafted some time in the early years of the last century. Before that it was of a now forgotten variety known to our great-grandfathers as "high top." Of late sprouts from below the graft on this old tree have come to maturity, and the visitor to the place may taste the same apples, with their sweet and pleasant flavor, that pleased the palate of the poet a century and more ago.

The old oaken bucket itself has passed and been replaced many a time since Woodworth's day; the wooden well-curb and the sweep, swinging in the upright crotch, have come and gone and come again. Curb and bucket and sweep are there today, similar in form and appearance no doubt and equally useful for the drawing of water, as near like those of which the poet wrote as is the water of to-day like that of his time. Even at the well itself the lapse of a century has left but one thing permanent. That is the cylinder of stone that walls it in. Here again, as in the walls surrounding the ancient fields, the stones that were the 
ball bearings of the glacier serve as the enduring monument of the pioneer. And in these we have the most lasting one that he could raise to himself. In the passing of enough centuries the slow heaving of frost and subsidence of thaw may throw out of alignment the carefully laid old stone walls. Nature herself in her own good time will throw down and scatter these tables of stone in which the early settlers wrote their laws of the fields. New owners will change those laws and use the stones for the foundations of other enterprises and thus in time will pass these monuments to the memories of the earliest occupants. It is not so with the old wells. They may fall into disuse, be covered over and filled in and forgotten. But the carefully laid cylinders of stone that enclosed them will remain out of reach of frost, untouched by man through indefinite centuries. Thirty, fifty, in some instances sixty and more feet beneath the surface they lie, and the man of a thousand years hence will find these memorials of early occupancy intact if he will but dig in the right place for them. The old well is the first settler's most enduring monument. I fancy the 
poem will outlast that, not for its singing quality which early caused it to be set to music that has lived along with the words, though that might well justify a green old age; not for its beauty of diction or its purity of thought, but because it voices a sentiment that the whole of humanity understands and approves. None so proud and none so mean but he knows the taste of that draught of cool water and the gratitude it inspires. To lean over the curb of the pioneer's well is to see your own face reflected as if with that of all mankind in a little circle that is the counterpart of the sky overhead. And out of the blue depths shines the gratitude of all mankind for thirst well quenched. Adam, or whatever the first man was called, thus gave thanks on his knees for a first draught from some clear spring and saw the sky reflected as he did so. Even the thoughts which "Home, Sweet Home" inspires do not go quite so far back to the beginnings of the race, nor is that song any more likely to live to remote times than is "The Old Oaken Bucket." 


\section{IX}

\section{IN OLD NEWBURYPORT}

The Dignity, Quiet, and Beauty of the One-Time Busy Seaport

Salt marshes surround Newburyport with their level beauty and through them you must come to it. Through them, too, the sea comes to it, stretching long arms lovingly as if to clasp it and bear it away. Thus fondly but placidly the tides twice a day give the gentle old city a hug and then go about their business. It is no wonder that this corner of old Newbury knew it belonged to the ocean rather than to the land and was set off as a seaport long ago. In the heydey of their affection the town sent forth its splendid ships in great numbers to all seas, and the seas in return sent tribute of all distant climes to Newburyport. For more than a century shipmasters and sailors born on the long ridge south of the Merrimac knew Guade- 
loupe and Surinam, Port au Prince and St. Martins as well as they knew the streets of their own towns, for the trade with the West Indies was very large. Ships launched at Newburyport and manned by her men brought back wine from $\mathrm{Ma}$ deira, carpeting, silks and glassware from Bilbao, salt from Cadiz and from Turk's Island, linen from Ireland, earthenware from Dunkirk. They brought back, too, knowledge of the wide spaces of the earth and distant cities, and it is no wonder the town grew in dignity as well as wealth, for it had a broad outlook upon the world. In the year I8Io, more than a century ago, twenty-one fullrigged ships, thirteen brigs and a schooner were built and set sail on maiden voyages from. Newburyport. On the first day of May, ten years later, forty vessels that had been held in port by contrary winds put to sea. The thought of such fleets makes the harbor lonely to-day when the only masts in sight are those of a coal barge or two, waiting for the surf on the bar to go down and let them out.

It is only a little over half a century since Newburyport saw the launching of a ship that was 
famous on all seas, her exploits woven into sea chanteys and ringing in hoarse chorus round the capstan in many a distant port while the men bent to the capstan bars, the pawl clicked, and ponderous anchors strained upward out of the ooze. That was the clipper-built Liverpool packet Dreadnaught. She was known as "The Wild Boat of the Atlantic" and "The Flying Dutchman." Twice she carried the latest American news to Europe, slipping in between steamers. Once in I860 she crossed the wind-swept western ocean in nine days and thirteen hours, from Sandy Hook to Queenstown, a pace which many an ocean-going steamship does not better to-day. She was conspicuous on all seas for the red cross painted on her foretopsail. "The Port" was proud indeed of this vessel; and as I stood on the top deck of the gray old custom house, looking down on the empty harbor on the one hand and up the ridge at the great square houses of the old sea captains and ship-builders on the other, I thought the wind crooned a snatch or two of deep sea chantey in memory of it round the gray stone cornices at my feet: 
"There 's a saucy, wild packet, a packet of fame,

She belongs to New York and the Dreadnaught 's her name.

She's bound to the eastward where stormy winds blow, Bound away in the Dreadnaught to the eastward we go.

Oh, the Dreadnaught 's a-howling down the Long Island shore,

Captain Samuels will drive her as he's oft done before, With every stitch drawing aloft and alow, She's a Liverpool packet; Lord God, see her go!"

Such was the building of Newburyport, and such is the romance of memory that comes in to her on every wind of the sea to-day, though the ships have sailed away never to return and even the foundations of the old ship yards are hard to find. The wealth and dignity of the old sea-faring days remain. The custom house bravely hoists its flag each morning and waits in gray silence for the cargoes that rarely come. Old age comes to it, though, and to climb the worn stairs to its top is to walk with the men of other years, hearing their footfalls in the echo of your own and seeing them vanish, phantoms of gray dust, through dark doorways into the forgotten past. Piled in the corners as they pass you see the outworn flags of other years, as if draping huddled heaps of the 
achievements of these phantom shipmasters. Perhaps in some dark corner lies another story like that of the Scarlet Letter.

Along the street on which the custom house faces passed the sea-faring traffic of the day, and the buildings suggest Wapping Old Stairs or some such quaint corner of old London near the Thames. The smell of the sea lingers round all corners, and in the little shop windows are crowded for sale pictures of ships and fragments of ship chandlery and curios from ports once a half-year's sail away; wares that one fancies have waited a century for customers. The street itself loves the sea so well that it is always trying to reach it, swerving toward the water line often and making detours when blocked, and always sending down little messenger side streets to bring it news from the very shore, thus winding its way always eastward till it gets an unobstructed view of the harbor entrance across Joppa flats and is no doubt content, strolling there along the very margin with a blear eye turned seaward for the ships that come no more.

In the débris the centuries have dropped along 
this once busy street the quaint and curious mingling of useless utilities and unvalued treasures, one is reminded of the quaint and curious char: acters such surroundings seem to evolve. Among such Dickens finds an Old Curiosity Shop and its keeper and makes them immortal. Yet it is not often that the queer character himself goes into print and leaves his name and pokes his personality into the dusty corners of literary fame, to be picked out and wondered at centuries after. Newburyport had one such, the story of whose amazing eccentricities still lasts, linked with the dignified reputation of the old seaport. These stories in time may be forgotten, though they have lasted more than a century, but his astounding book, "Pickles for the Knowing Ones," bids fair to last far longer, as long in fact as libraries collect and hold absurdities of print as well as literature. It is one of the ironies of fame that Newburyport, which can rightfully boast of being the town in which William Lloyd Garrison established his Free Press and wrote his anti-slavery broadsides, the town where Whittier's first poem was published, where Whitefield preached and John Pier- 
pont wrote the best of his patriotic verse, where Richard Hildreth began his work as a historian, where many another author of good repute was born, or lived, or died, where Harriet Prescott Spofford still lives and adds to her literary fame, should recall to the minds of many of us only the name of the preposterous "Lord" Timothy Dexter. After all, perhaps it is style alone which survives. Dexter's style was like nothing which ever went before or has yet come after, in print. It takes an inventive mind to find any meaning at all in what he wrote, sense being as scarce as punctuation, of which there was none. Yet the trail of Lord Timothy Dexter is still eagerly followed through Newburyport annals by people who forget that John Pierpont ever lived, and we all gloat over the punctuation marks added in a solid page at the end of his second edition, to be used as the reader's fancy dictates.

Lord Dexter lived in the solid, dignified upper portion of the town. His mind and character belonged in the queer junk in the little shop windows down near the water front. I can fancy John Pierpont drawing the clear, denunciatory 


\section{IN OLD NEWBURYPORT}

fire of his verses from the keen sea winds that blow on the top of the ridge where High Street is lined with the noble, square, stately old houses of the one-time magnates of the place. It is not a far cry from the shacks of Joppa and the clutter shops of the lower regions to this atmosphere of worth and dignity along the higher levels of Newburyport. I have an idea that more than one youth who climbed first to reef topsails later climbed to a master's berth and an owner's financial security, his abode climbing with him from the jumbled, characterless houses of the lower regions to one of these mansions in the skies. It may be that there is equal opportunity now, but it is not so easy to see. Seafaring and shipbuilding could not make men, but it did train them to wide outlooks and large experience in self-control and self-reliance; larger, I believe, than do the shoe factories and other industries that have taken their places in this town that the sea once made its own.

Newburyport does not grow in population, but it holds its own with a peaceful dignity and a quiet beauty that seem to belong to it as much as do its 
surrounding marshes. Leisure, peace, and an assured prosperity seem to mark the one as well as the other, whether ships come or go. There is little bustle, even at its busiest points, and you have but to go a little way from these to find as sweet a country as any part of New England has to offer. Passing up the river bank where the marsh grasses grow over the rotting stocks of the old shipyards, you find the hills coming down to meet the marshes and mingling with them in friendly converse. The town drops behind you, and gentle hillocks offer kindly asylum on the placid levels of the river bank, beauty spots full of half-wild life.

Here and there on these is an apple tree that has strolled down from suburban orchards as if to view the beauty of the river, and liked the place so well that it stayed, glad to escape the humdrum of ordered life, sending out wild shoots at will and producing fruit that has a half-wild vigor of flavor that puts the orchard apples to shame for their insipidity. They riot in lawless growth, these runaway trees, and welcome their boon companions, crows and jays, spreading an autumnal 


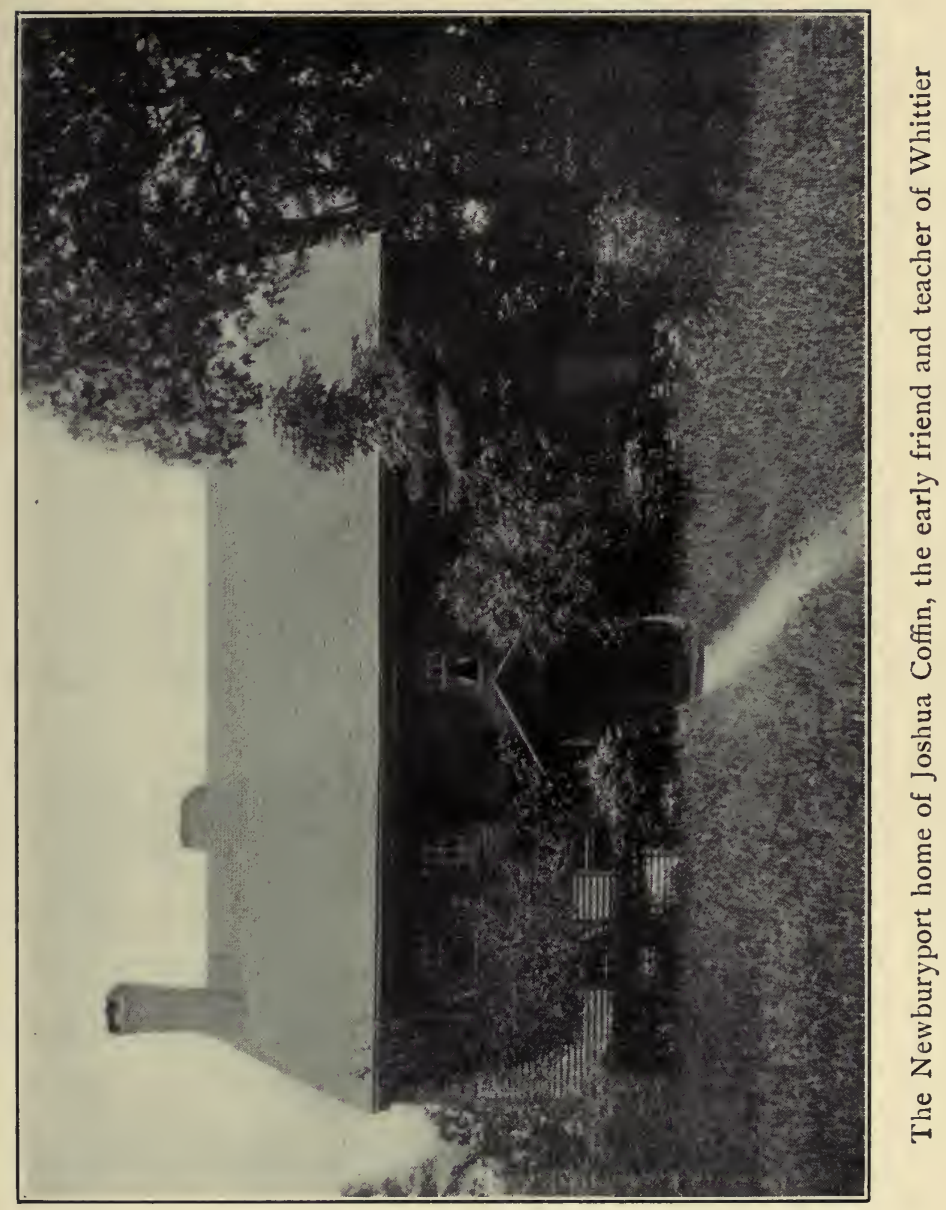



feast for their delectation and holding the fragments far into the winter that none may go away from a visit hungry. The pasture cedars, that love the river air, but may not live on the marsh, have built seaside colonies on these hillocks and spread a feast of blue cedar berries for all passing flocks. Here the robins, now gathering for their winter flight south, flock and feed, holding their ground at the approach of man, crying "Tut, tut!" to his intrusion. With them are the cedar wax-wings, also very fond of the cedar berries, the soft gray-browns of the bird's plumage blending most pleasantly with the olive greens of the cedars. There is a dainty, sleek beauty about this bird that harmonizes wonderfully well with the cedar trees which it frequents, and the little red sealing-wax tips on its wing feathers make one think that the flock is bringing Christmas decorations of holly berries to each tree to deck it for the holiday season. In wild apple trees the robins seem less than half-wild and in the cedars the waxwings more than half-tame. The two give a friendly spirit to the spot and at once make you feel that you are welcome. To sit quietly in such 
a place for five minutes is to make it your own home, and you go away with regret and a certain homesickness. Huckleberry bushes, maples, beach plums and birches stand admiringly round, and wild grasses and pasture flowers crowd in and add to the cosiness.

Of these wild flowers the seaside goldenrod is most profuse. Pasture-born like the cedars, it too loves the sea and crowds to its very edge like the people at Revere and Nantasket, so close indeed that at high tides the smelt and young herring, swimming in silver shoals, nibble at the bare toes the plants dabble in the water. You may know this even if you do not see the nibblers, for the plants quiver and shake with suppressed laughter at being thus tickled. The seaside goldenrod is prettier now in the cool winds and under the pale October sun's slant rays than it was in the heyday of August, when it burgeoned with yellow racemes of rather coarse bloom. Its head-gear is in the full autumn style, and it bows beneath the weight of ostrich-plume pappus and softens all the foreground of the view with gray fluff. 


\section{IN OLD NEWBURYPORT}

From these sea margins where tide and river mingle and meet the borders of Newburyport one gets glimpses of higher hills up-river, dark with pines and gorgeous with autumn scarlet and gold, and among them the picturesque towers and cadenced sweep of the old chain bridge that takes you across the river to Amesbury. Down river to the old chain bridge the rough rocks of the New Hampshire hills, wandering far, come to get a taste of salt, and put their lips to the water at the island home of Harriet Prescott Spofford, whose sparkling verse and piquant prose has made the name of Newburyport known in literary annals for more than half a century. Hills and sea meet there, and all the beauty of marsh, pasture and woodland surround the spot. It is no wonder that romance, vivid life and rich atmosphere inform her work.

The herring gulls which go up and down with the tides no longer follow the Newburyport sails to sea and escort them back again to port, pensioners on the bounty which ships always scatter in their wake. Instead they have reverted to their original, more noble trade of fishing. Every 
time the smelt or the young herring come in to make game of the seaside goldenrod by tickling their toes they risk their lives. The gulls soar and wheel over the shallows and tide rips, their wings and bodies set and quiet like soaring monoplanes, their heads hanging loosely on supple necks and turning this way and that as they peer with farsighted eyes at all beneath the surface. Suddenly the stays of the monoplane seem to break, the wings crumple, and the bird falls to water as if shot, going often beneath the surface. In a second he emerges with lifted bill and you see the silvery flash of some unlucky fish disappearing down the capacious gullet. Often this is a polite morsel, but not always. The gull is not over particular in his mouthfuls, and I have seen one take a herring. as long as his own body, head first, swallowing the fish as far as circumstances would permit, then sitting placidly on the water with several inches of shiny tail protruding, waiting, like continuous performance table d'hôte diners, for the first course to be digested so that there should be room to swallow the last one. Birds of the sea meet birds of the land here, and birds of the marsh 


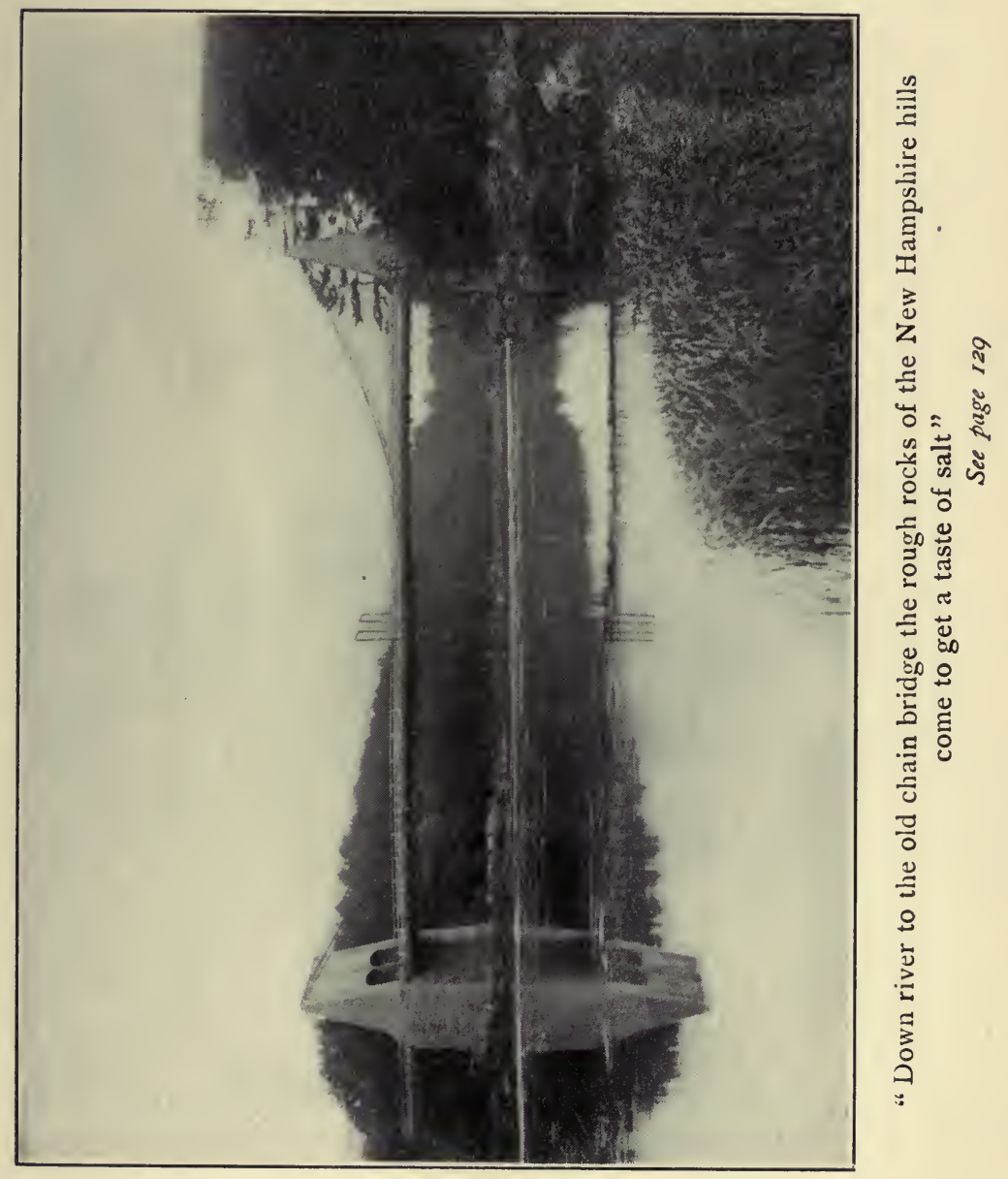





\section{IN OLD NEWBURYPORT}

join them. Over the river the fish hawk soars as well as the gulls, and the marsh hawk crosses from one mouse-hunting ground to another. Out of the sky a Wilson's snipe fell like a gray aerolite, while I was there, a lightning-like plunge ended by an alighting as soft as the fall of a thistledown on the marsh grass. This was proof that the drought has been long, for the Wilson's snipe likes the fresh water meadows best and rarely comes to the salt marsh grass unless his familiar stabbing ground is too dry to be thrust with comfort. He came like a visitor from another sphere. In the second of his lighting I caught a flash of his mottle gray and brown, then he vanished as if his plunge had after all taken him far into the ground and all you need expect to find was the hole by which he entered. Yet neither bird nor hole could I find by diligent search in the marsh grass. Never a top waved with his progress among the culms, and only by scent could he have been followed.

On the other side of Newburyport you come to the marshes again, great level stretches of them, silvered with winding threads of the sea that seek 
far through the slender creeks, marshes dotted at this time of year as far as eye can see with the rounded domes of many-footed haystacks, a place where the full sky is yours for the seeing, where all winds blow free, and blowing bring to your lungs the rich, life-giving scent of the deep sea tides, caught and concentrated in the tangled grasses and touched with a faint essence of their own perfume. Beyond again lies Plum Island. Here the sea beats in savage vigor, and I seem to get in its voice an echo of the sonorous poems in which John Pierpont denounced slavery. Pierpont was one of the great writers of his day, and his work lasts. He may well have got the culture, depth and dignity of his multitudinous sermons from the atmosphere he found among the great square houses built by the old-time shipmasters and shipbuilders on the ridge which is the backbone of the city. In the laughing beauty of the up-river scenery I can fancy him finding lightwinged fancies such as the couplet he wrote in Miss Octavia's album:

"Octavia; what, the eighth! If bounteous heaven Hath made eight such, where are the other seven?" 
Only in the deep sea thunder of the waves on Plum Island beach could he have heard such notes as echoed in "The Tocsin":

"Ay - slaves of slaves. What, sleep ye yet,

And dream of freedom while ye sleep?

Ay, dream while slavery's foot is set

So firmly on your necks, while deep

The chain her quivering flesh endures

Gnaws likes a cancer into yours!"

It is easy to see him striding home from a session with the Plum Island waves and pausing to see the snow settle on and blot out the outlines of the peaceful marshes, drawing from the sight his best-remembered, most-quoted verse:

"A weapon that comes down as still As snowflakes fall upon the sod, But executes the freeman's will

As lightnings do the will of God; And from its force nor doors nor locks Can shield you; ' $t$ is the ballot box."

I do not know if he wrote these lines here or later when he had become one of Boston's famous preachers, but I do know that he saw these things in the years that he lived in the fine old town and 


\section{LITERARY PILGRIMAGES}

carried the memory of them long with him, just as all of us who visit the place carry away lasting impressions of its quaintness, dignity and wholesome quiet, and the beauty of its surrounding country. 


\section{$\mathrm{X}$}

\section{PLYMOUTH MAYFLOWERS}

Adventures of a Spring Day in Pilgrim Land

The first day on which one might hope for mayflowers came smilingly to Plymouth in late April. The day before a bitter northeaster had swept through the town, a gale like the December one in which the Pilgrim's shallop first weathered Manomet head and with broken mast limped in under the lee of Clark's Island. No promise of May had been in this wild storm that keened the dead on Burial Hill, yet this day that followed was to be better than a promise. It was May itself, come a few days ahead of the calendar, so changeful is April in Pilgrim land. The gale, ashamed of itself, ceased its outcry in the darkness of full night and the chill of a white frost followed on all the land.

In the darkest hour of this night I saw a thin point of light rise out of the mystery of the sea far to the eastward, the tiny sail of the shallop of the 


\section{LITERARY PILGRIMAGES}

old moon, blown landward by little winds of dawn, making port on the shore of "hither Manomet." In the velvety blackness of this ultimate hour of night the slender sail curved sweetly backward toward the sea, and the shallop seemed drawn to the land by a lodestone, as was the ship of Sinbad the Sailor, and when it magically climbed the dark headland and sailed away into the sky above it drew out of the sea behind it the first light of glorious morning. From Manomet head to the Gurnet the horizon showed a level sea line of palest garnet that deepened, moment by moment, till the coming sun arched it with rose and bounded from it, a flattened globule of ruby fire. I like to think that the path of gold with which the sun glorified the stippled steel of the sea was the very one by which the first Mayflower came in from Provincetown, the sails nobly set and the ship pressing onward to that memorable anchorage within the protecting white arm of the sandspit.

I like to think that the sweet curve of the old moon's slender sail sways in by Manomet each month in loving remembrance of that other shallop that so magically won by the roar of the breakers 
on the dark point and brought the simple record of faith and courage for our loving remembrance. But whether these things are so or not I know that the very first rays of the morning sun pass in level neglect over the bay and the town to lay a wreath of light on the brow of Burial Hill and touch with celestial gold the simple granite shaft that stands over the grave of William Bradford, historian of Plymouth Colony and writer of the first American book. Such is the unfailing ceremony of sunrise in Plymouth, and such it has been since the first Pilgrim was laid to rest on the hill which lifts its head above the roofs and spires to the free winds of the world.

Plymouth is fortunate in this hill. It bears the very presence of its founders above the enterprise and ferment of a modern town which grows rapidly toward city conditions, a hill which is set upon a city and cannot be hid. Factories and city blocks and all the wonders of steam and electrical contrivance which would have astounded and amazed Bradford and his fellows are common in Plymouth to-day as they are common to all cities and towns of a vast country, yet the graves of the 
simple pioneers rise above them as the story of their lives transcends in interest that of all others that have come after them. The book that Bradford wrote, as the tales that Homer told, will last as long as books are read. Plymouth may pass, as Troy did, but the story of its heroes will remain. Bradford's book, which was our first, may well, at the end of time, be rated our greatest.

The trailing arbutus is peculiarly the flower of Plymouth. Not that it grows there alone, indeed within easy reach of the landing place of the Pilgrims it is not easy now to find it. Once, no doubt, it blossomed about the feet of the pioneers, sending up its fragrance to them as they trod sturdily along their first street and through their new-found fields that first spring after their arrival. My, but their hearts must have been homesick for the English May they had left behind! and in memory of the pink and white of the hawthorn hedges they called this pink and white flower which peered from the oval-leaved vines trailed about their feet, mayflower. It surely must have grown on the slopes of Burial Hill, down toward Town Brook, but now one will look in vain for it 
there. I found my first blossom of the year by following the brook up to its headwaters in Billington Sea. The brook itself is greatly changed since Bradford's day. Its waters are now held back by dams where it winds through the sand hills, and one mill after another sits by the side of the ponds thus formed. Yet the "sea " itself must be much the same in itself and its surroundings as it was in Billington's time. Nor do I wholly believe the legend which has it that Billington thought it was a sea in very truth. It is too obviously a pond to have deceived even this unsophisticated wanderer. It covers but a little over three hundred acres including its islands and winding coves.

I think, rather, its name was given in goodnatured derision of Billington and his idea of the importance of his discovery, a form of quaint humor not unknown in the descendants of the Pilgrims to this day. Yet the waters of the little winding pond are as clear as those of the sea which breaks on the rocks of Manomet or the Gurnet, and the hilly shores, close set with deciduous growth, are almost as wild as they were then. The robins that greeted the dawn on Burial Hill sang here at 
midday, blackbirds chorused, and song sparrows sent forth their tinkling songs from the shrubby growths. Plymouth woods, here at least, are a monotony of oaks. Yet here and there in the low places a maple has become a burning bush of ruby flame, and along the bog edges the willows are in the full glory of their yellow plumes. The richest massed coloring one can see in the region to-day, though, is that of the cranberry bogs. Looking away from the sun the thick-set vines are a level floor of rich maroon, not a level color but a background showing the brush marks of a master painter's hand. Toward the sun this color lightens and silvers to tiny jewel points where the light glances from glossy leaf tips. The later spring growth will fleck the bogs with green, but the maroon background will still be there.

The arbutus does not trail in all spots beneath the oaks, even in this secluded wilderness. Sometimes one thinks he sees broad stretches green with its rounded leaves only to find last year's checkerberries grinning coral red at him, instead of the soft pink tints and spicy odor of the Epigæa blooms. Sometimes the pyrola simulates it and 
cracks the gloss on its leaves with a wan wintergreen smile at the success of the deception. But after a little the eye learns to discriminate in winter greens and to know the outline of the arbutus leaf and its grouping from that of the others. Then success in the hunt should come rapidly. After all Epigæa and Gaultheria are vines closely allied, and it is no wonder that there is a family resemblance. The checkerberry's spicy flavor permeates leaves, stem and fruit. That of the arbutus seems more volatile and ethereal. It concentrates in the blossom and rises from that to course the air invisibly, an aromatic fragrance that the little winds of the woods sometimes carry far to those who love it, over hill and dale. Given a day of bright sun and slow-moving soft air and one may easily hunt the Plymouth mayflowers by scent. Even after the grouped leaves are surely sighted the flowers are still to be found. The winds of winter have strewn the ground deep with oak leaves and half buried the vines in them for safety from the cold. Out from among these the blossoms seem to peer shyly, like sweet little Pilgrim children, ready to draw back behind their 
mother's aprons if they do not like the appearance of the coming stranger. Perhaps they do withdraw at discretion, and this is very likely why some people who come from far to hunt find many mayflowers, while others get few or none.

Just as the Mayflower in which the Pilgrims sailed to Plymouth seems to have been but one of many English ships of that name, so the trailing arbutus is not the only flower to be called mayflower in New England. The mayflower of the English fields and hedgerows was pre-eminently the hawthorn, known often just as "the may." But there is a species of bitter cress in England with showy flowers, Cardamine pratensis, which is also called mayflower, and the name is given to the yellow bloom of the marsh marigold, Caltha palustris, often known, less lovingly, as "blobs." The Caltha is common to both Europe and America, and, though it is often hereabout known by the nickname of "cowslip" which the early English settlers seem to have given it, I do not hear it called mayflower. In localities where the arbutus is not common the name mayflower is here most commonly given to the pink and white 


\section{PLYMOUTH MAYFLOWERS}

Anemone nemorosa, the wind flower of the meadow margins and low woods, and to the rock saxifrage, Saxifraga virginiensis, both of which are among the earliest blossoms of the month.

None can visit Plymouth without wishing to climb the bold promontory of " hither Manomet." The legend has it that Eric the Red, the Viking who explored the New England shores centuries before the first Englishman heard of them, made this his burial hill and that somewhere beneath its forests his bones lie to this day. I sought long for mayflowers on the seaward slopes and in the rough gullies of these "highlands of Plymouth." I did not find them there.

On the landward slopes, gentler and less windswept, down toward the "sweet waters" that flow from inland to the sea, you may with patient search find many. But the heights shall reward you, if not with mayflowers with greater and more lasting joys. The woods of Manomet were full of butterflies. Splendid specimens of Vanessa antiopa danced together by twos and threes in every sunny glade, the gold edging of bright raiment showing beneath their "mourning cloaks" 
of rich seal brown. Here in the rich sunshine Launcelot might well have said:

"Myself beheld three spirits, mad with joy,

Come dashing down on a tall wayside flower."

Here Grapta interrogationis carried his everpresent question mark from one dry leaf to another, asking always that unanswerable "why?" Here Pyrameis huntera, well named the hunter's butterfly, flashed red through the woodland, scouting silently and becoming invisible in ambush as a hunter should. Here a tiny fleck of sky, the spirit bluebird of the spring which the entomologists have woefully named Lycæna pseudargiolus, fluttered along the ground as if a new-born flower tried quivering flight, and brown Hesperiidæ, " bedouins of the pathless air," buzzed in vanishing eccentricity. But it was not for these that I lingered long on the seaward crest. There below me lay the bay that the exploring Pilgrims entered at such hazard, that but the day before had been blotted out with a freezing storm and gray with snow, now smiling in unforgettable beauty at my feet, bringing irresistibly to mind the one who sang, 


\section{PLYMOUTH MAYFLOWERS}

"My soul to-day is far away, Sailing the blue Vesuvian bay."

At Naples indeed could be no softer, fairer skies than this June day of late April brought to Plymouth Bay and spread over the waters that nestled within the curve of that splendid young moon of white sand that sweeps from Manomet to the tip of the sandspit, with the Gurnet far to the right and Plymouth's white houses rising in the middle distance. It lacked only the cone of Vesuvius smoking beyond to make the memory complete.

Nor has the Bay of Naples bluer waters than those that danced below me. Some stray current of the Gulf Stream must have curled about the tip of Cape Cod and spread its wonder bloom over them. Here were the same exquisite soft blues, shoaling into tender green, that I have seen among the Florida keys. Surely it was like a transformation scene. The day before the torn sea wild with wind and the dun clouds of a northeast gale hiding the distance with a mystery of dread, a wind that beat the forest with snow and chilled to the marrow; and this day the warmth of an Italian spring and the blue Vesuvian Bay. 
The Pilgrims had their seasons of storm and stress, but there came to them too halcyon days like this when the mayflower bloomed in all the woodland about them, the mourning cloak butterflies danced with joy down the sunny glades, and the bay spread its wonderful blue beneath their feet in the delicious promise of June. Nor is it any wonder that in spite of hardships and disasters manifold they yet found heart to write home that it was a "fayere lande and bountiful."

But for all the lure of Plymouth woods with their fragrance of trailing arbutus, from all the grandeur of the wide outlook from Manomet Heights, the hearts of all who come to Plymouth must lead them back to the resting place of the fathers on the brow of the little hill in the midst of the town. There where the grass was not yet green and the buttercups that will later shine in gold have put forth but the tiniest beginnings of their fuzzy, three-parted leaves, I watched the sun sink, big and red in a golden mist, over a land of whose coming material greatness Bradford and his fellow Pilgrims could have had no inkling. Seaward the tropic bloom of the water was all 
gone, and there as the sun passed I saw the cool steel of the bay catch the last rays in little dimples of silver light. Manomet withdrew, blue and mysterious in the haze of nightfall. Out over the Gurnet, and beyond, the sky caught purples from the colors in the west, and there, dropping below the horizon line, east northeast toward England, I saw a sail vanish in the soft haze as if it might be the first Mayflower, sailing away from the heavy-hearted Pilgrims, toward England and home. The sun's last ray touched it with a fleck of rose as it passed, a rose like that which tipped the petals of the mayflowers that I held in my hand, mayflowers that sent up to me in the coolness of the gathering April night a fragrance as aromatic and beloved as is the memory of the lives of the Pilgrims that slept all about me on the brow of Burial Hill. Bradford wrote gravely and simply the chronicles of these, and no more, yet the fervent faith and sturdy love for fair play, unquenchable in the hearts of these men, breathes from every page, a fragrance that shall go forth on the winds of the world for all time. 


\section{$\mathrm{XI}$}

\section{OLD SALEM TOWN}

A Scarlet Letter Day in the Witch City

Over all the hum of business activity that rises from Salem town sleeps the glamour of old-time memories. Factories drone, traffic roars or clatters, and the multiple message of modern civilization goes forth to eye and ear, but among all these sits the ancient city dreaming long dreams and careless of the children of to-day.

Along Charter Street and down Derby the once stately mansions of the great merchants of another century droop in senile decay, knee deep in the dust and debris that immigrant, alien races scatter, and note it and them no more than they do the rats in the wainscoting. The thoughts of the old houses are busy still with ships in the China Sea, battling round the Cape of Good Hope with the Flying Dutchman, or running down the trades from Senegambia, Surinam or Ceylon, 
and their upper window eyes stare unwinkingly across rotten wharves and out to the island gaps in the horizon of the bay, watching for the sails that come no more. So the world thinks of Salem to-day as the city of romantic memories. It may weave cotton cloth and tan hides and make shoes and carry on a thousand other inventions of modern business, yet we who dwell away from it, far or near, will always know it best for its romance of elder days, the dread delusion of its witch finding, the astounding deeds of its merchant sailors, and in the end most of all perhaps, for its man of dreams, Nathaniel Hawthorne, who dreamed there the grim story of "The Scarlet Letter" and made it live for all men for all time.

More and more, as the years slip by, Hawthorne comes to be the presiding genius of Salem, and reverent pilgrims in increasing numbers come to seek the few abiding traces of his life there; and though they go to Gallows Hill and also view the relics of the old merchants and their portraits and the pictures of their ships, they go first to the house where Hawthorne was born, to the other houses 
where he lived and worked, and to the sleepy, dignified old Custom House from whose drab duties grew the strange flower of weird romance. It may be that out of the Ghettos and Warsaws which now surround the old Custom House will come again as great merchants as once dwelt there, or as great a writer of romance as he who worked on its scarred old wooden desk now preserved with such care in the Essex Institute, but one may be pardoned for having his doubts. The world matures rapidly, and the heritage of primitive environment and primitive opportunity is smoothed out by the steel roller of modern invention. New ports no longer wait the seaman adventurer. Steam makes all ports common, and the knowledge of them common, to all the world. We shall look long for the successors to Derby and Peabody and their ilk, and we may well doubt if ships like The Grand Turk, Rajah and Astræa will sail again from any future Salem.

Never again, the world surely hopes, can come upon a pioneer people so mysterious a madness as the Salem witchcraft delusion, yet in it were set the roots of temperament which made Hawthorne 


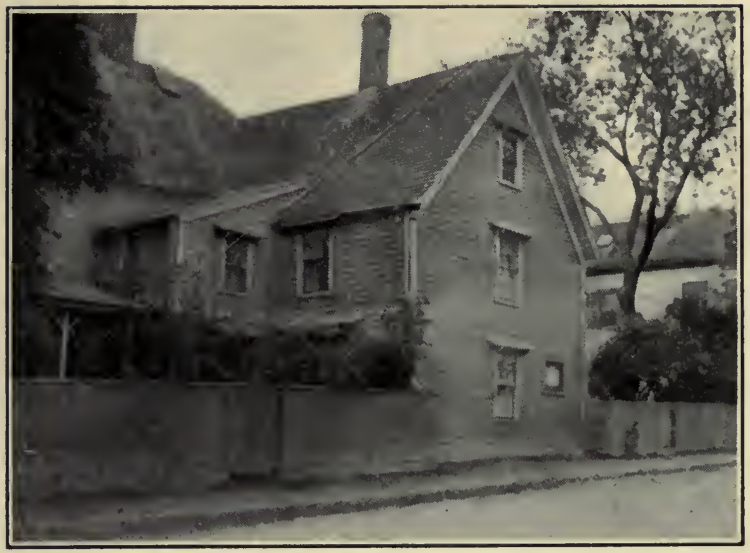

One angle of "The House of the Seven Gables"

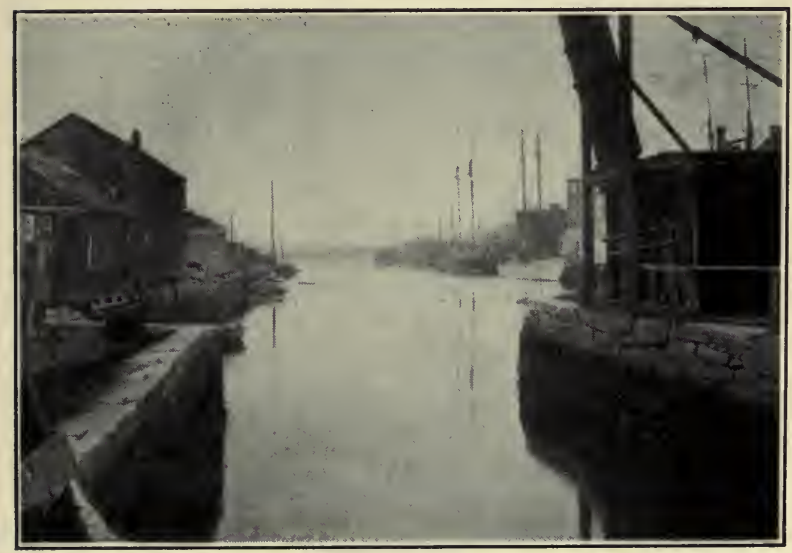

A Salem dock of the old sea-faring days 

what he was. Its grewsome mystery seems to brood in all he wrote, and one cannot visit his haunts and the scenes of its terror to-day without feeling some atmosphere of it still hovering over the place. Hawthorne's ancestor sat in judgment over the witches, and Judge Hathorne, invisible indeed but grimly onlooking, seems to me to preside over many a tale which he wrote. As relentless fate mocked the witches while it gripped them and killed them with trivialities, so it does the characters in Hawthorne's stories, nor in the progress of events is there room in the tale, in the one case or the other, for the saving grace of humor. From Hathorne to Hawthorne came the somber impress of the days of witch finding.

The spring sun and the spring rain fall alike gently on Gallows Hill, yet it stands bare and wind-swept to-day as it did when the witches met their fate there, as it has stood since the glaciers ground over it, no one knows how many hundred thousand years ago. The tough rock of which it was built shows everywhere the traces of the fires which melted and reset it in its present form, its 
twist and coloration burnt into it as the story of the deeds wrought on its summit is seared into the annals of old Salem town. Here and there on its fantastic ledges one sees zigzag marks struck pale as if lightning had welted the tormented stone and left the impress of its sudden anger there. The softening years can do little with this rock. A curse far older than that of the witch finding has set its seal upon the height, and though the gentle things of earth strive patiently to ameliorate the evidence they do little to wipe out the bleakness of the place. The green of spring grasses climbs patiently toward the topmost ledges, indeed, and draws with it the gold of potentilla and the white of wild strawberry blooms. Dandelions set the round image of the sun in sheltered places, and little lilac constellations of bluets star the moister spots adown the slope, but the barren soil is too shallow and the summer turns all these to a brown garment of sorrowful sackcloth and sprinkles it with the gray ashes of drought.

A few houses have boldly climbed the hill from the street below, but none has yet dared the very 
spot on the bare, red-gray summit where the irons that once helped support the gibbet rust, still firmly bedded in their holes in the rock. Over the ledges and down the hill to the southeast lies a little pond of sweet water that sparkles in the spring winds, cosily sheltered in the hollow and surrounded by the vivid green of smooth turf. But even this the long scorn of summer heat dries to a brown bog where sedges fight for the life remaining in the stagnant pool in its center. About this pond the barberry bushes have found a foothold in straggling clumps to bear little crosses of witch-pin thorns, and steeples of hard-hack blooms spire solemnly near it in summer. Potentilla and cudweed dare the slope toward the summit of Gallows Hill when the rain and sun are kind, and fragaria and violets and bulbous buttercup trail after, but even in the soft days of May the height where the witches were hung is desolate and forbidding. Yet it dominates the outlook upon the town as the story of the witchcraft delusion dominates the annals of it, as both will for all time.

Yet, for all its bareness, the country about Gallows Hill has its golden days. These come in late 
June, when it seems as if the sun had wrought a miracle among the bleak ledges and along the treeless slopes. Everywhere then in the seemingly barren pastures springs up the shrubby, lanceolate-leaved genista, clothing them in a rolling sea of its golden bloom. For weeks then the hills are glad with a wonder of papilionaceous yellow blossoms that any other pastures, however prolific of beauty, find it hard to match. The same Puritans that cherished the witchcraft delusion brought this plant with them from England, the dyer's greenweed, woadwaxen or whin, and as they passed on into history left it behind them. It has wandered far in the waste places in New England, but nowhere does it so clothe the hills and rough slopes with beauty as it does in the region about Salem. The thought of this, already pushing up through the sod, is best to take back to the city with one. As the good in the Puritans was far greater than their grim misdeeds, so this goes far to hide the bleakness of the ledges, as it seems striving to. Perhaps some day it will even overgrow and hide the iron in the summit of the hill where children play to-day, and make them 
forget the story of its tragedies which now they are so eager to tell to the visiting stranger.

Salem's golden days began a century or more after the witchcraft delusion had burnt to ashes in the fury of its own fire. Certainly the descendants of the men who feared the devil and his emissaries feared little else. He might be formidable dancing at night with withered crones on the weird hills of Salem pastures, but they laughed in his face when he came on the high seas with shotted guns and foreign sailors outnumbering their own guns and crews two to one. They beat the devil and they outgeneraled him, those Salem sailors of the seventeen hundreds, whether he came in English privateer or French man-o'-war or a score of feluccas or piratical junks, and they brought great treasures home to Salem town. They explored uncharted seas, visited ports unheard of before and carried the name and fame of their home town the world over. The world has made a great hero of Paul Jones, but there were half-a-dozen young sea captains out of Salem in Revolutionary times who did all that he did, and more, yet did it so unostentatiously and so much 
as a part of the day's work that the records of it are hard to trace and for the most part have been lost. During the Revolution Salem sent out ${ }^{8} 8$ armed vessels carrying more than 2000 guns. They took 445 prizes, losing in return fifty-one of their own fleet. Jonathan Harraden, for instance, sailed from Salem in the privateer General Pickering, I80 tons, carrying fourteen 6-pounders and a crew of less than fifty men. Thus manned and equipped they captured a British privateer of twenty-two guns. Harraden put a part of his crew on the captured vessel and the two sailed on. Off the coast of Spain they sighted a vessel bearing down upon them, and the captive British captain laughed as he told Harraden that this was the British frigate Achilles of forty-two guns.

"Well, I shall not run from her," said Harraden, stoutly; and he did not. The big frigate soon recaptured the prize with its short crew, but the little Pickering laid up alongside of her at nightfall when the battle ceased for want of light. Harraden went to bed and got a good night's sleep. In the morning the battle began again so 
near the coast that a hundred thousand Spaniards made the hills black with spectators. The disparity in size of the two vessels was such that an eyewitness said it was like a ship's long boat attacking a man-o'-war. But the little boat won the battle, and not only the big frigate but the recaptured prize struck to the indomitable Salem captain and his fearless Salem crew. The battle was no sooner over than the sea was black with the boats of admiring Spaniards who came out in great numbers and later took Captain Harraden ashore and carried him about the city on their shoulders. Report does not state whether the captain enjoyed the ride, but at least he must have been proud of the admiration which called it forth. Sailing again after the battle with the Achilles, Harraden met three British ships of the size of his and captured the three of them, one after another. In all during the Revolution this one Salem captain took from the British more than a thousand guns and sent home great wealth in prizes taken from the far stronger sailor nation with which his country, one might almost have said his town, was at war. 
Joseph Peabody was another Salem sailor whose fame was to outlast the Revolution and grow greater in the succeeding days of hard-won peace. In those following days of peaceful, or at least semi-peaceful trading adventure, Peabody owned, first and last, 83 ships which he freighted himself. In his time he shipped 7000 seamen and promoted 45 men from cabin boys to captains. In Salem ships these cabin-boy captains, often striplings of nineteen or twenty, sailed the seven seas, opened new ports to commerce, conquering the prejudice of potentates, matched their wits and wisdom against those of skilled merchants of the Orient and brought back princely profit to the ship owners of Salem and in part to themselves, for often captain and crew alike shared in the profits they helped to make. In those days the Chinese called the Yankees " the new people," for they first heard of them when Salem ships visited their ports, and the list of new lands first visited by American ships from Salem is a long one.

It was in November, 1785 , that the Grand Turk, belonging to Elias Derby and commanded by Ebenezer West, cleared for Canton, China, the 
first American ship to seek this round-the-world port. Seventeen months after she returned, the result of her voyage, for one thing, being a cargo that brought her owners twice more capital than she had carried out. The Salem merchants often sold not only the cargo but the ship itself in these far distant ports, and later the Grand Turk was thus disposed of in India, Derby building another and a larger vessel of the same name. In I794 Salem owned 160 vessels of a tonnage totaling 16,788 tons. In 1805 this number had increased to 54 ships, 18 barques, 72 brigs and 86 schooners, of which 48 were employed in trade around the Cape of Good Hope. In I 806 there were 73 ships, I I barques and 48 brigs, all engaged in this foreign trade, which gave such splendid opportunity for adventure and such princely returns. Cargoes have been brought into Salem port that realized 800 per cent on the capital invested, and from $\mathrm{I} 800$ to $\mathrm{I} 807$ inclusive $\mathrm{I} 542$ vessels in the foreign trade arrived, paying an annual average duty of $\$ 755$, I 57.90 , and this at the Io or 12 per cent ad valorem which was the reasonable rate of those days. 
In the story of this Salem shipping from 1775 to 1875 is an Odyssey that some latter day Homer may yet make ring down the future ages. The captains and crews of these ships needed all the courage and wisdom of Ulysses, nor had sea-worn Odysseus so wide wanderings or so strange adventures as they.

In Hawthorne's time this age of Homeric adventure had indeed passed from the port, yet Salem ships still sailed the seas, for in 1847 , when he was dreaming of Hester Prynne, her preacher lover and her weird and satanic husband, as he bent over that old desk in the custom-house, 78 vessels cleared from Salem for foreign ports. So true it is that one's eyes see only what they are fitted to see. All about the dreamer were the records of these mighty adventures told for the most part indeed in invoices and clearance papers, but also, one must believe, echoing in the traditions which his snug-harbored mariner confrères must have known, yet no story came from his pen that shows he felt the call of the sea to those keen, daring sea rovers on whose trail he camped. This was no loss to us, doubtless. We would not swap 
the "Scarlet Letter" for any tale that Stevenson told. Yet think what fancies would have taken shape in Stevenson's brain out of the dusty ghosts that still linger in the nooks of the old customhouse!

More things than these are hidden away in Salem. The homing instinct of the old sailors brought back from the seas of all the earth thousands of strange relics which are still to be seen in the magnificent Peabody Academy of Science and in the Essex Institute, institutions free to all the world of which the city is justly proud. Yet the home-keeping instinct of those who remained behind was as strong, and the Salem homes of the days of the merchant princes still remain, in some cases much as they were a century and more ago. Now and then, within the uproar of a busy street one gets a glimpse over a high board fence of gardens of quaint beauty, the gravel walks bordered with prim box, the sward of a century green and smooth, and the hardy perennials that the old-time home-keepers loved and tended growing and blossoming there still, as beautiful and deep-rooted as were the lives of the Salem mothers that sent their 
sons forth to adventure on the seven seas while they waited and wove love and longing into the beds of garden bloom. The modern city has crowded these for long, yet the atmosphere of their brave beauty remains still and belongs with the square, patrician dignity of the houses.

In one of these gardens I glimpsed an oriole, flashing his tropic colors along the branches of a magnolia, now just in its wonder of white bloom. It was as if white patience of mother love had waited him there, a gay young wanderer from Surinam, where, very likely, he had spent the winter on an annual voyage. Gay and restless he was, and his mellow voice prattled no doubt of all the strange sights he had seen and the adventures he had met, while the fair tree enfolded him in her. arms and worshiped him with the tender home perfume of mother love. It made me wonder a little, too, why Hawthorne missed the orioles in the Salem gardens which he must have seen each spring, and only birds of such somber colors flitted through the flowers of his fancy. But after all it was only one more proof that out of the inner eye 


\section{OLD SALEM TOWN}

come the colors of our thoughts, and that the inherited shadows of the witch-finding days must have dwelt deep in the soul of the Salem-born, Puritan-descended dreamer of weird and somber romances. 


\section{XII}

\section{VERMONT MAPLE SUGAR}

Sap-Boiling Time in the Green Mountain State

At ten o'clock the sap began to tinkle all through the grove. In nearly eight hundred buckets it fell, drop by drop, and the sugar season had begun. It was late March, but from the snow to the sky the day had all the warmth and glow of June. The sun had been up since before six. By seven it was shining bright into the Southern Vermont valley which the Deerfield River has carved out of the everlasting hills that roll and rise till the cone of Haystack tips them, nearly four thousand feet above the sea level. Yet till ten o'clock the maples sulked.

More sap is boiled in this beautiful bowl-shaped valley of which Wilmington is the metropolis than in any other part of the State. Vermont makes four-fifths of the maple sugar that is made in New England, nearly half of what is made in the United 
States, and here if anywhere you may see the art practised in its perfection. There may be better sugar makers than C. S. Grimes, who has been at it for sixty years, but if so I do not know them. He began with the old-time black iron kettle, boiled in the open over a green wood fire. He has seen the business grow in the sugar house to the use of scientifically accurate evaporating pans where sap flows in a steady stream into one end and comes out syrup of a law-required density of eleven, pounds to the gallon at the other, the whole working automatically; and in that time he has learned something of the whims of the maples themselves, though not all of them.

Much of the lore of the great gray trees he told me as we sat together on the broad doorstone of the little white farmhouse, steeping in the sun and looking down upon the peaceful valley and across to Haystack, hazed in the blue smoke of spring. Everything was ready. The spiles were driven and the white, pent-roofed pails hung. The woodhouse end of the sugar house was full to the top of four-foot sticks ready for the boiling. Even the pan was full of sap, for there had been a slight run 
a week before. But the cold had shut down and the trees had quit. The morning before the thermometer had stood at zero and the sap in the pan was ice. So, no doubt, it was in the trees, and would be until the warmth had reached the heart of them. I learned more in the grove as the patient old horse drew the sled through a foot or two of old snow, and we gathered the crystal-clear sap from the buckets and poured it into the barrel, plodding from tree to tree. More still I got in the sugar house while the veteran fed the roaring fire and skimmed the scum from the boiling liquid as it flowed, an inch deep or so, along the winding channels, back and forth, sap at one end, syrup at the other.

The white men learned from the Indians the art of making maple sugar. In the "Philosophical Transactions of the Royal Society," published in I684, we find the following: "The savages of Canada in the time that the sap rises in the maple make an incision in the tree by which it runs out. After they have evaporated eight pounds of the liquor there remains one pound as sweet and as much sugar as that which is got out of the canes. 
The savages here have practised this art longer than any now living among them remember."

The white man has since brought the practice to a science. The art remains the same. How far back into the dim ages of the past it goes no man may tell.

The sugar maple reaches maturity at about a hundred years. Then in the forest the trees are seventy to eighty feet tall and have a diameter of two to four feet. Trees grown from seed produce the sweetest sap, second growth not being so good. The seedling under favorable conditions may reach a diameter of sixteen inches in fifteen years, though such growth is exceptional. It is not profitable to tap them before the age of twenty. After that they may be drawn from yearly, a tap to a tree at first. On the largest trees two or more buckets may be hung, never one above the other, as the sap flows up or down, never sidewise. The sweetest and best sap comes from the outermost ring of growth, the wood of the previous year. It is sweetest at the height of the run. It flows better by day than by night; the brighter, lighter and sunnier the day the 
faster it flows, the trees resting more or less at night. As the sun declines, so does the flow, even when the temperature remains the same. On warm nights, however, there is likely to be some flow. Daytime sap is sweetest, and the nearer the occurrence of a freeze or a snowstorm the sweeter the sap. Light seems to be a powerful agent in the mystery, but a certain balance of heat and cold is more powerful still. Freezing nights with alternating warm days bring the ideal conditions, frozen roots and warm twigs setting the alchemy at work.

Yet with all this and much more general knowledge to draw from each grove is a study. The maples are strongly individualistic, and every tree is a law unto itself. Some have a much higher percentage of sugar to the same amount of sap than others. Indeed, it is confidently predicted by experts that a race of superior trees could be easily developed by taking seed from those of highest sugar percentage, just as superior fruit trees are thus bred. The profit to the sugar-maker from this is obvious. The future may see it done. As conditions exist the average 
yield of sugar per tree is from two to three pounds, though in favorable seasons this is increased in some groves to five or six pounds. On the other hand there are records of large trees which have yielded as much as forty pounds of sugar in a season, and many have been known to give twenty pounds. Sometimes a certain tree on a farm gets to be known as "the sweet tree," because of the large amount of sugar it yields yearly.

The sky held a faint violet haze which deepened to royal purple in all distances, a violet which seemed to materialize into innumerable bluebirds which caroled coaxingly as they flew toward the grove. Over on the edge of it song sparrows sang invitingly, but the sugar makers did not move from the cosy doorstep until nearly noon. Then we went toward the grove somewhat warily, as a man tends his traps in the wilderness, rather hoping for luck but doubtful. The sap moves when it gets ready, and no man can surely say when. But a look into a bucket or two told us that the time was at hand for quick action. From every tree a clear, colorless liquid was oozing with 
rapid drip into the buckets, some of which were a third full already. It looked like water, this new-born sap, as clear as that from the finest spring, yet to my eye it seemed to have a certain radiance, not a sparkle like an effervescent liquid, but something purer and more effulgent, as if the nascent life in it touched something in you by nerves dormant to ordinary sensations. The sugar cane gives up its juice only to force. It must be crushed and pressed. But here is a sweetness which the tree almost bursts to deliver, which will not only drip from every wound, but will force its way with overmastering prodigality. If instead of putting a hollow oaken tap into the three-eighths inch auger hole bored through the bark you drive in a solid plug, the sap will push through the very pores of the oak wood. No wonder when it reaches the twig tips the buds are driven into action and the blossoms burst with astonishing vigor that nothing can delay. There is little sweetness of taste to this wine of the wood gods, but a cool, delectable refreshment that is born of the free winds and mountain air. It tempts you to drink deep and often, and I sus- 
pect that Vermonters do and have since the State was first settled. No State has given to the nation more sturdy, dependable, keenly vitalized, strong-souled men and women than this, from the days of Ethan Allen down, and it may be that deep draughts from the potent purity distilled by the rough-barked, rock-rooted maples has more to do with it than we know. Maple syrup ought to be recommended to the schools. I believe it would increase scholarship and promote ethics.

The gray grove was like a temple of white stillness as we went from tree to tree. The only sound was the crunch of soft snow and the splash of sap within the barrel, a cool sound like that of sea waves curling on the rocks. A pair of white-breasted nuthatches ran deftly among the branches and seemed to respect the hush of the place, calling to one another in tiny tones that only emphasized the quiet. Here was the gray column of a beech, its smooth trunk looking as if carved out of mottled marble. There stood a yellow birch with a fringe of flaxen curls. But for the most part the growth was of maples alone and with little underbrush, so that we looked be- 
tween the trees down to the valley below and up its further side till the gaze touched the sky on the distant blue summit of Haystack. It was easy to note with what feathers and fur the earth keeps herself warm in the fierce cold of Vermont winters. In the distance the black growth of evergreen spruce and hemlock would hardly let the roughest gale pass within. Where these do not stand interwoven the misty mingling of the twigs of deciduous trees made a cloak that was softly beautiful to the eye yet hardly less penetrable, and over all the cleared spaces and under all other protection was the white ermine of the snow. The March sun and the thawing rains of approaching spring had settled this snow ermine closer to the ground, indeed, but had only compacted it more firmly. A foot or more of it was everywhere and you could plunge to the shoulders in the drifts.

Soon the gathering barrel was full and the horse plodded back to the sugar house, where from the hillside the sap ran into the sapholder, a twentyone barrel cask propped up within, thence to go by gravity through a tube to the pan. Here the 

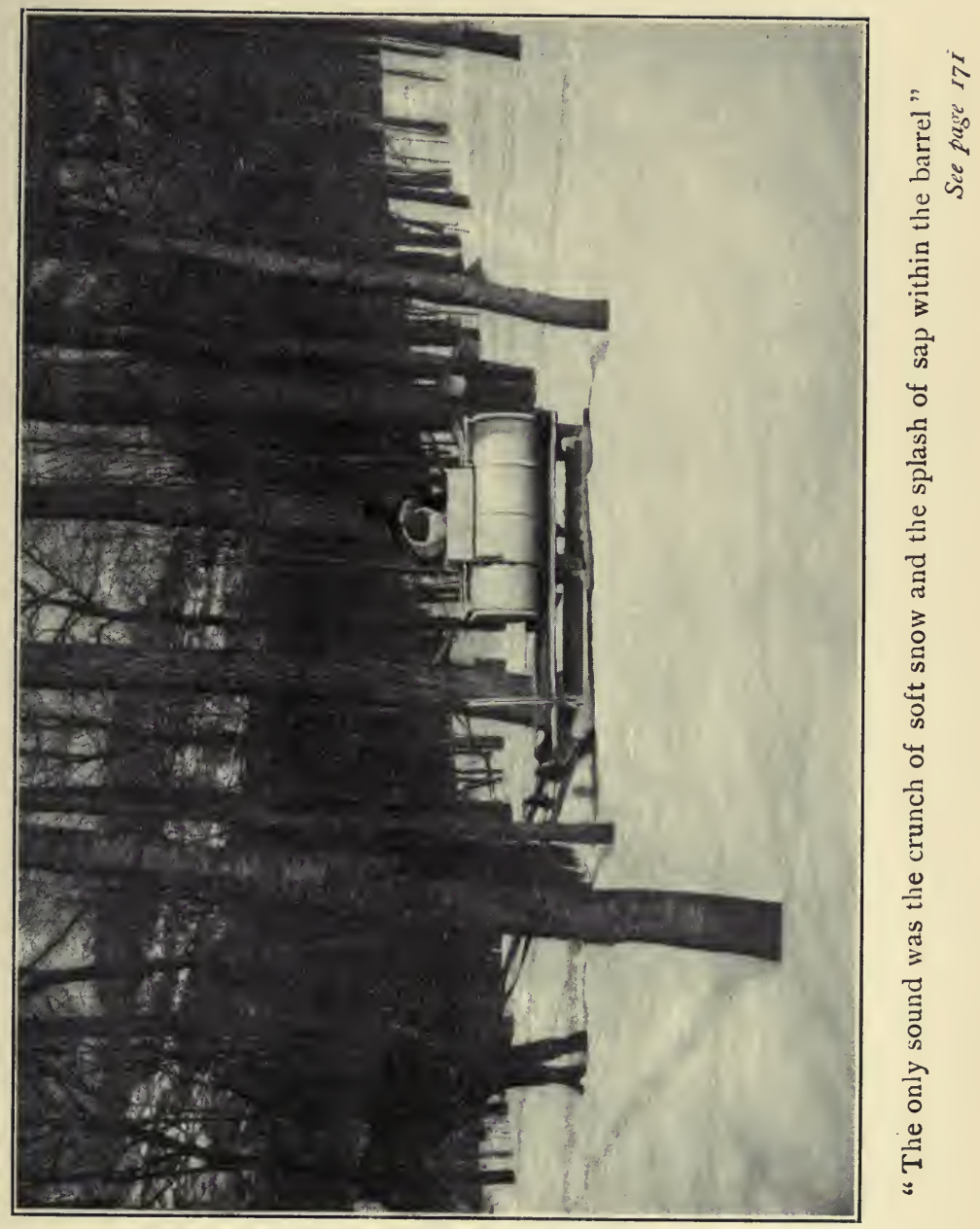

elder Grimes was busy, feeding the roaring fire with four-foot sticks, skimming the scum from the boiling sap and drawing the syrup into gallon cans at the other end. Sugar making is no job for a lazy man, even though the pan regulates the flow of the sap automatically, nor is it nowadays to be conducted without some capital. The plant is a small one, yet here, counting house, tools, tanks, pan, buckets, etc., was an investment which easily figured up a thousand dollars. The clear liquid from the trees ran in a steady stream, and the boiling sap bubbled and frothed in one end and collected in palest amber shallows in the other. Now that the run is started from eight to thirty barrels of sap a day will come to the sugar house, taxing the powers of the sugar maker to the uttermost to keep ahead of the flow. It does not do for the sap to wait. The best syrup is made from it when first collected and it will spoil if the delay before boiling is too long. Often the fires roar and the sap boils for the greater part of the twenty-four hours. It may be one or even three o'clock in the morning during a good run before the man at the pan can let his fire go out 
and snatch a few hours' sleep. If the night has been warm gathering may begin again soon after sunrise and again he must be at his fires.

It is at the sugar house that the business of making maple sugar has lost much of the romance of old days. The big black kettle in the little shed or the open woods with its sugaring-off frolics by the boys and girls is a thing of the past. In its place you have a small factory equipment running overtime, with much of the regularity of factory drudgery, while the short season lasts. Yet it is a godsend to the farmer. His winter's work in the woods is done. His farm work has not yet begun, and the sugar brings in many hundred dollars in ready cash, readier cash than he gets on any other farm product. Good syrup brings from $\$ I$ to $\$ 1.25$ a gallon, and on a recent year it was estimated the returns from maple sugar averaged over $\$ 3$ each for every man, woman and child in the State. That of course is gross returns, not profits. These vary so greatly in individual cases and in various years that it is impossible to get at the net result. Some Vermont farmers do not think that sugar 
pays, and many have even gone to the extent of cutting off their groves for wood, preferring the cash from the trees once for all. This, of course, is killing the goose, for it greatly depreciates the value of the farm. Indeed it is an axiom in the Green Mountain State that a farm without a sugar orchard is an unmarketable commodity. For all that it is safe to say that for one reason or another not half the available trees in the State are tapped yearly.

Even about Wilmington this is true. I should say that there not one grove in three is being worked this year. To begin with, there is the investment in "sugar tools," no light expense for the man of small capital. Good sugar workers are not so common as they once were, and require good wages when they are to be obtained at all. It is customary to pay a man fifty dollars a month and his board, and his wages run whether the sap does or not. A start may be made and then adverse weather or the idiosyncrasies of the trees may keep the gang waiting a week, or even three. Even the men hired by the day get two dollars to two and a half. In some years the snow is 
not deep and the run of sap steady and prolonged. Then the farmer makes money. During other years the snow may be so deep that it is necessary to shovel out the roadways in the grove and go from tree to tree on snow shoes. Last year, owing to peculiar weather conditions, there was but a light run of sap, and it was soon over, lasting hardly three weeks. In consequence the crop was light. Yet maple sugar is distinctly a luxury for which the demand is greater than the present supply, and is likely to steadily increase. It is probable that the planting of large areas to especially productive trees on which the most scientific business methods were used would result in large profits. The trouble is that the season of production is short and all trees must be worked at the same time. Moreover, it takes twenty years for a seedling maple to grow to producing size, and the average investor does not care to wait that long for the first of his returns. In any case, it is a matter for the capitalist rather than the farmer, who does not usually look so far ahead for returns on his money.

Along with the improvements in the sugar 
house have come many in the methods of getting the sap from the trees. The pioneer method was to "box" them. This meant cutting a receptacle in the tree itself large enough to hold a pint or so. of the liquid which ran into it. Boxing, year after year, was destructive to the trees which, nevertheless, survived a vast amount of it. It is probable that boxing has not been carried on in the Vermont groves for more than fifty years, yet there are trees standing to-day which show marks of the old-time method. On what was known once as the Kathan farm, just west of the Connecticut River in Dummerston, still stand a few trees of what is believed to be the first grove in the State from which white men made maple sugar in any quantity. Thirty-three of these veterans were there in 1874 , but now only nine remain. They are gigantic trees, free of limbs to a great height and one at least sixteen feet in circumference. At the base can be seen the knotted, uneven growth covering the scars of nearly seventy years of "boxing." After the boxing method came the tapping iron, almost as hard on the trees. A slanting kerf, an inch deep and four inches long, was 
first made. Then the iron with a half-circle cutting edge was driven in deep at the bottom of this to make a place for the spout of hard wood, grooved with a gouge and finished with drawshave and pocket-knife. Troughs of white maple or basswood, split in halves, dug out with the axe and smoothed with the gouge, were used to catch the sap, which was gathered in hand-made pails hung from a "sap-yoke" which rested on the bearer's shoulders and took the weight.

The boiling was in the big black iron kettle which the elder Grimes remembers so well. It was hung by chains from a pole set up on two crotched sticks. Beneath it were two big green logs between which the fire was kept. Sugar houses were unknown and dry wood was rare, yet with care a respectably clean sugar was made.

A piece of wood taken from one of these trees in I873 is still preserved in Vermont. It is twenty inches by four, yet it shows five boxing places, two deep in the wood and three that the later growth of the tree had not been able to cover. Sugar was made from these trees in 1764 , and they were tapped each year by some member of 


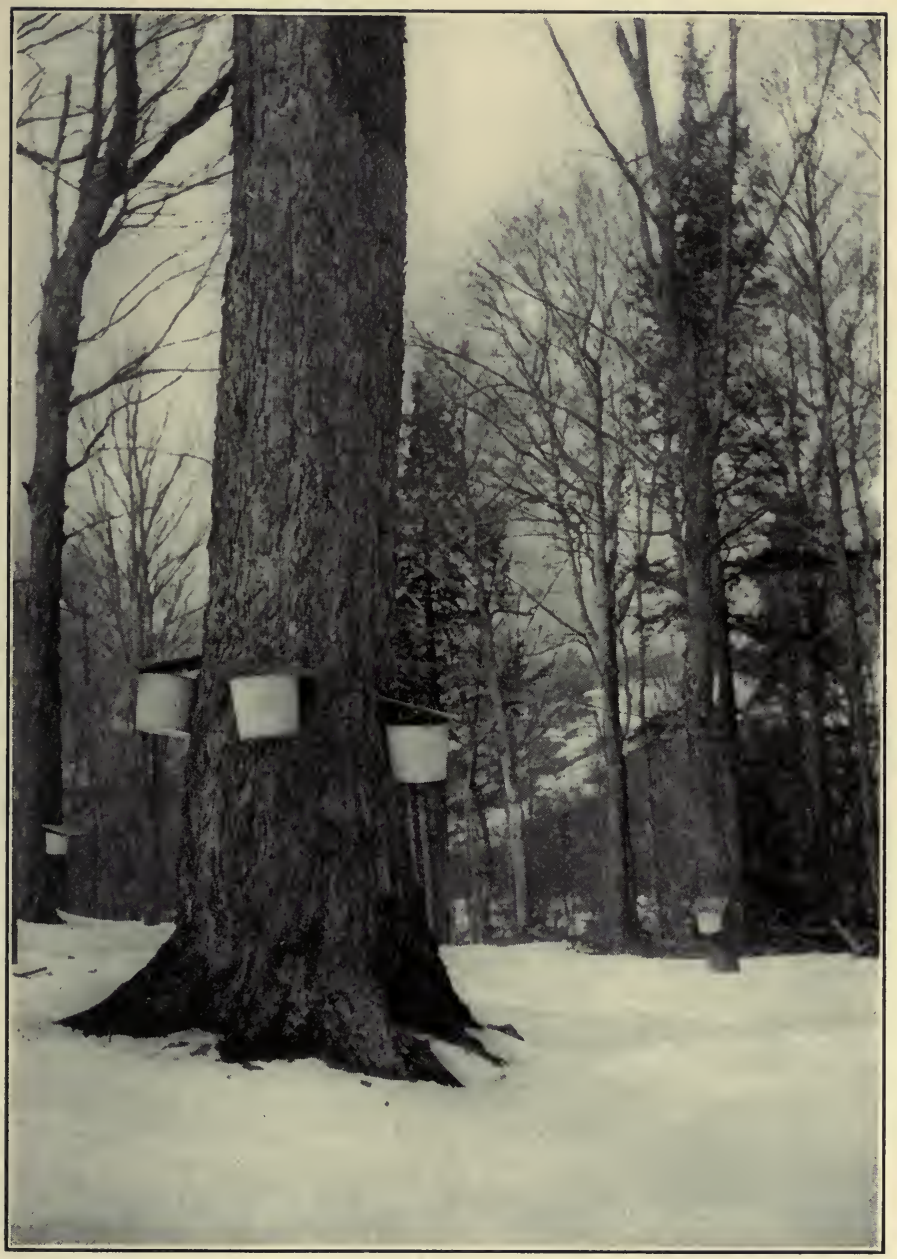

"But here is a sweetness that the tree almost bursts to deliver" 

the Kathan family until 1862 . One of the largest of these trees was cut in 1858 , and the number of concentric rings of growth showed that nearly a hundred years had then passed since the tree was first boxed for sap. In 1894 another was cut, having a box mark only three inches beneath the surface of the wood, showing that in this tree at least someone had gone back to the ancient method not more than half a generation before the date of cutting the tree. Probably scattered trees of the groves of a century and a half ago still stand in other portions of the State, carrying deep in their heart wood the scars of the old-time sugar making.

The Vermont laws against the adulterating of maple sap products are now quite strict, and it is probable that original packages from the State are reasonably sure to be what they are sold for. The syrup weighing eleven pounds to the gallon is practically at the point of saturation, a gallon weighing even an ounce more than this showing a deposit of crystallized sugar. It was formerly considered that the intermixture of cane syrup could not be detected, but modern methods of 
chemical analysis show it, the ash from dried and burned maple sugar being greater than that from dried and burned cane sugar in that it, having not been recrystallized, still contains other chemical constituents of the sap. These no doubt contain the ingredients which go to make up the delectable flavor, and those not yet isolated elements which help make the Vermonters the big-hearted, big-souled people that they are. Yet the rich golden brown color which most maple sugar has is not a quality of the sugar itself, but due to impurities, harmless but unnecessary. They come from tiny flecks of bark which fall into the sap or from careless boiling. Before the sap gets to the can in the Grimes sugar house it has been strained seven times. The iron kettle sugar of the old days was sometimes almost black. Care in the handling will give a syrup that is almost as colorless as water and a sugar that is nearly white. Hence color in the final product by no means indicates purity, though it may in no sense indicate adulteration. The best syrup is a clear, viscous, pale straw-colored liquor, and the sugar itself need not be much if any darker. 
To an outsider the whole trip into the upper valley of the Deerfield River is a delight. At Hoosac Tunnel the big train gets tired of the long climb and plunges into the very heart of the mountain. But the little narrow-gauge road takes up the ascent most determinedly. The boy's-size engine snorts and chu-chus up astounding grades, winding into defiles where the mountains close in on each side and almost squeeze the track into the river. At some stations the stop is on such a slant that the engine puffs and grinds for minutes before any progress at all is noticed. The town comes down to see the struggle, and the small boys call the conductor and engineer by their first names and rail at their' railroading. "Hey, Bill," says one. "What's your coffee mill grinding today?" Then, as the imperceptible first motion accelerates to a snail pace, they stroll along with the engine and continue their chaff till the hills shut down and cut them off. Yet after all, when you consider the grades, the curves and the stops, the whole trip is made at a good pace, the twentyfour miles being covered in about an hour and a half. Coming down is coasting, and the speed is 
limited only by the requirements of safety. Vermont whole-heartedness runs through the train chaff, however, and the favorite salutation is "neighbor." To take the trip is like attending a lodge meeting, and long before the final stop you feel a friendly interest in everybody present. If you don't know most of the others by their first names it is because you have not kept your ears open. At this season at least you learn how strong a hold the good old business of sugar making still has on the hearts of the people of the Green Mountain State, and the gossip of the groves and farms is yours without the asking. The free, wholesome air of the mountains is in it all, and as you breathe more and more of it you feel that the good oldtime New Englander does not need to come back. $\mathrm{He}$ is there, up under the purple shadow of Haystack, talking maple sugar and drawing its essence of vitality from the white wood of mighty trees that clothe mountain slopes with the kindly peace of their stately groves. 


\section{XIII}

\section{NATURE'S MEMORIAL DAY}

How Earth and Sky Observe this National

\section{Holiday}

Up to the brow of Cemetery Hill

The serried battle ranks still press to-day.

The saxifrages in Confederate gray

Charge to the robin's bugle, piping shrill.

In Union blue the sturdy violets still

Shoulder to shoulder in the battle sway

And, rank on rank, the rising onslaught stay,

While cheers of song-birds through the woodland thrill.

And yet peace reigns, and both the gray and blue

Mingled in garlands on the field will lie

Marking a soldier's grave, or blue or gray,

Shoulder to shoulder waiting, who shall say?

We only know they wait beneath the sky

While garlands deck them, wet with tears of dew.

In my town the little "God's Acre" in which the pioneers snuggled to sleep under the protecting shadow of their first rough church has grown over hill and dale to a score of acres. The church long since moved out of its own yard, as if to give the pioneers room, yet lingers gently 
within a stone's throw, as a mother waits within sound of her children. Where once the rough oak timbers stood squarely upon their field-stone foundations century-old graves stretch restfully side by side, and gray lichens cling so close to the blue slate of headstones that the twain become one, and the very names of the sleepers beneath are hidden and forgotten. Shoulder to shoulder these old stones stand and lean friendlily one on another, as brothers to whom the kindly elder years have brought surcease of all differences. The early settler's were bold in their beliefs and battled sturdily for them while it was time to fight. The ancient records and traditions will tell you of stern warfare waged between man and man and clan and clan. Then, the battles well fought, they laid themselves down side by side in a forgiving neighborliness that is the most lasting inscription on the plain stones that mark their rest. Peace is most secure between those who have fought best, and the Memorial Day spirit is no mere growth of our later years. It was born in the scheme of all good, just as battles were.

Nature voices for us only kindly memories. 
Whatever the chisel may have graven on these rude slate stones, the kindly sun and rain and the slow sobbing of the earth's bosom under frost and thaw have taught them "de mortuis nil nisi bonum" till they voice it in phrases which none who pass may fail to read. The lichens have written it and the actions of the slate speak louder than the words of the inscriptions. We in our Memorial Day offerings tell for a brief hour only what the good gray earth has been saying the year through, and we say it best, as she does, in flowers and tears. Nature's Memorial Days began with the first grave and have continued ever since. Ours, which began with our mourning for dead heroes of the Civil War, has extended since to those of all wars and moves yearly nearer to Nature's all-forgiving, all-loving teaching. Our lesson will be complete when we understand that all who have lived are heroes and that toward all who are dead we should bear constant loving remembrance. The sun and the rain lead the gentler things of earth to this all through the old cemetery where, since the pioneers of the town, have come the heroes of the Revolution, of 1812 , 
the Civil War, and of countless un-uniformed battles of daily life before and since.

All the morning of Memorial Day children, and often their elders, glean from field and wood, from garden and greenhouse, flowers for the decking of graves, and later the thinning ranks of Grand Army men march to martial music and place upon the graves of dead comrades the flag for which they fought and garlands of remembrance. For these the mowing fields give gladly the white and gold of their buttercups and daisies, the hillsides the blue of their violets, the woodlands the feathery white and glossy green of the smilacina. It always seems as if these blossomed their best for the occasion. But beyond all other flowers in profusion and beauty for the ceremony is the lilac. This shrub, I am convinced, knows that its best service to man is in garlands for Memorial Day, and rarely does it fail in the service. There come years in which the spring is cold and backward and blossoming shrubs are weeks behind their accustomed time of bloom, but the lilacs press bravely forward, hopeful even at the very last moment, and manage to put forth 
flowers by the thirtieth of May. On other years, like this, all things are three weeks or more ahead of season, yet the lilacs hold steadfastly on, and when their need is felt there they are to be gathered in armfuls from willing bushes that go cheerfully at work again to repair the wrecked stems and provide buds for the garnering of another year. The lilac should be the flower of poets and heroes, and as we are all that, however humble our heroism or however shyly hidden our poetry, it is fitting that it should be commonest for the decorations of Memorial Day.

For the lilac, for all its buxom profusion and its ability to take care of itself in neglected fields and woods where the garden in which it was once delicately nurtured is grown up to grass, the house to which it belonged is crumbled to ruin, and wild woodland things crowd and choke it, is of royal lineage. In the garden of what prince of prehistoric days it first bloomed I cannot say, but it was beloved of Babylonian kings and mingled its perfume with that of the roses in Persepolis when Persia was a seat of learning and refinement, while western Europe was yet to emerge 
from savagery and America was not even a dream. There Jamshid, founder of the then mighty city, Rustam the hero who defended it all his life from barbarian invaders, Sadi the poet in his rose garden, Omar with his "jug of wine and thou" watching the stars and writing his fond, cynical, keen verses, and even Genghis Khan and Tamerlane, barbarian conquerors out of the mysterious farther east, must have sat beneath its shade from time to time as the centuries dreamed on and dreamed their own dreams of conquest, of love or of service, under the spell of its fond, pervading perfume. Dreams these should be, of love, if you will, of constancy, and of hope and yearning toward high ideals, for all these breathe from the true heart of the lilac to-day, nor has the passing of three centuries changed the subtle essences of the flower or their meaning one whit. How far these have gone to the changing of the hearts of men in that time one may not say, but surely the fragrance sighs through the Gulistan and the Rubaiyat and the culture and refinement that the Persia of those days has sent down the years to us in their records was greater than that of any 
other nation of the time. From this mother land of the lilac spread westward the belief in one God. There the learned men taught to princes and nobles a due reverence for parents and aged persons, a paternal affection for the whole human species and a compassionate tenderness even for the brute creation. There before the sovereign in state might appear the humblest peasant for justice, and the youth of the land were taught fortitude, clemency, justice, prudence, to ride a horse, use the bow and speak the truth. With the odor of these things that of the lilac filled the air there through centuries of springs. What more fitting flower could we lay upon the graves of our heroes, whether of the Civil War or the Revolution, whether wearing the blue or the gray, or the homespun of the battle of every-day workshop, farm or home? There is more of symbolism in its giving than we heed. With the loving remembrance of friends of to-day goes a greeting from heroes of an age long gone but not forgotten.

There is no remembrance of civilization, no aura of human nobility about the smilacina, which 
in my regard comes next as a flower for $\mathrm{Me}$ morial Day. Hardly the violet could be more modest. Its tiny spike of white bloom is borne only a few inches high on a two-leaved stalk, the leaves in shape and gloss reminding one of the florist's smilax, whence probably the name. Yet its very simplicity makes it peculiarly a flower for garlands. The leaves, growing on the stalk itself, make just the right amount of green, and a nosegay or a wreath of smilacina alone has a dainty beauty that few flowers could thus give. The misty white blooms on the glossy green seem like shattered tears of gentle spirits of the woods bringing their tribute of sorrow to the fallen heroes. Nor are the blooms of this plant which the school children have gathered and which the veterans have placed on the graves the only ones that are there. All along one side of this cemetery the woods themselves press their sheltering beauty, and in them the earth is garlanded with smilacina blooms. Passing from Memorial Day observances to these I often think that the forest itself decorates in honor of its own whose resting places would be otherwise un- 
marked. It may be for the people of an elder race all other traces of whom are lost that the tiny, lovely flowers group their white and green, or for the humbler creatures of the wood who would otherwise lack tokens of mourning, but the smilacina certainly decorates the mounds in all woodlands with mystic tracings which have their own meaning. But it does more than this. In modest beauty it slips shyly out from the sheltering friendliness of the pines and stands with bowed head on many a dewy Memorial Day morning by such mounds as it may reach, in all gentle friendliness.

Shyer yet are the saxifrages which sometimes stand near by. These I have seen, clad as if in Confederate gray, by a mound which veterans had marked with a Union flag and along which tiny blue violets nestled lovingly. So, surely, they stand in mute respect and nestle as lovingly by many another spot where the remembered one fought as bravely beneath another flag. Long ago the good brown earth taught the blue and the gray to thus fraternize, and though we forgot it for a time the lesson came soon back to us with 
renewed force. The saxifrages and the smilacina have not ventured far out of the all-sheltering wood, but the Confederate gray is borne all over the score of memorial acres by the wild immortelles, everlasting, as the children call them, and no caretaker's rake or lawnmower can keep these down, or clip the violets so close that their blue fails to nestle lovingly where heroes lie. All over the place from spring until autumn these two set their garlands side by side, as do those who mourn on the one Memorial Day of the year. Thus constant are the sun and rain and the tiny herbs of the brown earth.

As the boldest soldiers in the fray held oftenest the foremost ramparts and felt themselves fortunate in their position, so I think it must be with those veterans who rest nearest the brow of the hill, where it seems as if they could look forth over miles of beautiful forests to the blue hills which are other ramparts on the horizon. Here of an early morning of this misty May they might well think they saw gray troopers form and advance in battalions that sweep down from the hills to eastward and charge over the treetops of the vale 


\section{NATURE'S MEMORIAL DAY}

below. Through the distance they can hear the bugle calls of thrushes, and with trained ears thus know in what formation the advance will be made and when. Well may they feel the old-time thrill of desperate conflict as the advance sweeps up their hill and the misty gray legions swarm over it until the fight must need be hand to hand. Yet rarely does a day pass without final victory for the blue. The misty legions fall back and vanish before the flashing cavalry of the sun and the blue battalions of the clear sky swarm forth and drive the enemy in full retreat before them. Thus to them again out of the shades may come Gettysburg, or Antietam, or Port Hudson.

I like best, though, to think of them here as resting in camp with no thought of battles past or to come, the mists that rise meaning no more than the smoke of comrades' campfires, the bird bugle calls only those of the day's routine. 'From a hundred treetops they may hear the robins sound the reveille. From their hilltop these bugle notes should wake even the soundest sleepers. No other bird is so well fitted for this call. There is a sprightly persistence in the robin's song of a 
morning, a recurrence of rollicking refrain which reminds one strongly of the awakening notes of the bugle as they ring through the camp when the last of the night watches is ended and the new day calls all to be up and stirring. The robins are peculiarly the buglers of the reveille. No bird sings earlier, and when the full chorus is in swing there is little chance for any other bird to be heard. No wonder the sun gets up betimes.

The day calls, the assembly, the retreat, the mess call and a score of others are left to other birds than the robins. The thrush may pipe them. Grosbeak, tanager or warbler may trill the familiar melodies for all these, and a host of others sing at any hour of the day in tree or shrub or in the pine woods that stand in a phalanx, like a company under arms, pressing close up to the brow of the hill. Sometimes I hear these in the sweet, flowing warble of the purple finch which is not rare hereabouts, but more often in the notes of the warbling vireos which frequent the tops of the shade trees. These are all-day buglers, piping clear for all occasions in firm, rich, continuous notes of whose meaning there can be no 
doubt, once you have learned the calls. Nearing these and seeing the white marble of the newer comers stretch far beyond the slate headstones, over hill and dale, it is not difficult to believe these indeed the tents of an army corps and to think I hear in response to the bugle the marching tread of feet that have been resting long. The tramp of the boys in blue on Memorial Day, as they march and countermarch, passing from station to station, the ringing call of the bugle that sang across Southern fields all through Grant's campaign could not seem much more real.

When the busy day is ended it is the wood thrush that sings taps. The dropping sun reflected from polished white marble lights campfires from tent to tent, fires that shall burn low to glowworm embers presently, their smoke curling up in night mists from the dewy ground. It is then that the friendly forest seems to crowd closer as if to surround the camp with a host of faithful guards. Then out of its violet dusk rings the call of the wood thrush, a call full of gentle mystery, of faith and longing, at once so sad and so sweetly hopeful that it seems to voice all human 
sorrow for mortality and all human, wistful belief in immortality. "Come to me," it pipes in tintinnabulating richness out of the deepening dusk. "Good night; good night; all's well; good night." No sweeter music than taps ever rang from bugle or from throat of wood thrush when deepening twilight falls upon this white-tented corner of fame's eternal camping ground. The buttercups that stray lovingly among the graves of the pioneers give up their gold to the sky that sends its tears to dew their round eyes. All day the good gray earth and the brave blue sky have held memorial service, and as the last note of taps rings from the throat of the thrush deep in the sheltering wood the night takes up the service with wet eyes. 


\section{XIV}

\section{BIRDS OF CHOCORUA}

Some May Songsters of the Frank Bolles Hiniterland

To all who love the lore of woodland life the country up around Chocorua lake and mountain must always be haunted by the gentle spirit of Frank Bolles, whose books, all too few, breathe the very essence of its perennial charm. To nature lovers who come year after year to the place these books are a litany, and all the bird songs are echoes of the notes he loved. Nor need there be an hour of the twenty-four in this region, in May, in which the birds do not sing. No night is too dark for the wistful plaint of the whip-poor-wills, wandering voices that seem born of the loneliness of the bare places in the hills before man was. To the wakeful ear their sorrow hardly seems soothing, yet when drowsiness comes from long days in the mountain air the whip-poor-will's plaint is a primal, preadamite 
lullaby that as surely sings to sleep as does the cadenced sorrow of the wind in the pines or the minor murmur of a mountain brook, intermittently tossed over the hill by the night breeze. Often at nightfall the " clackety clack, cow, cow, cow" of the yellow-billed cuckoo sounds through the Chocorua woods, as if a lanternless watchman were making his rounds and sounding the hour with his rattle. Often, too, some songbird will rouse from sleep as if he heard the cuckoo watchman, going his rounds, pipe him a sleepy bar or two of his day song, notes strangely vivid in the perfumed darkness, then drowse again with the melody half finished. But of all these the whippoor-wills are most persistent and loudest. They greet the dusk with antiphonal chant, and when they finally follow the shadows to rest in the darkest wood the choir of day takes their silence for its matin bell.

Something of Bolles's purity of diction and sweet content in the gentle joy of life in the fields and woods, the sapphire cadences of distant mountain peaks and the chrysoprase tremolo of young leaves, seems to have come from the song of the 


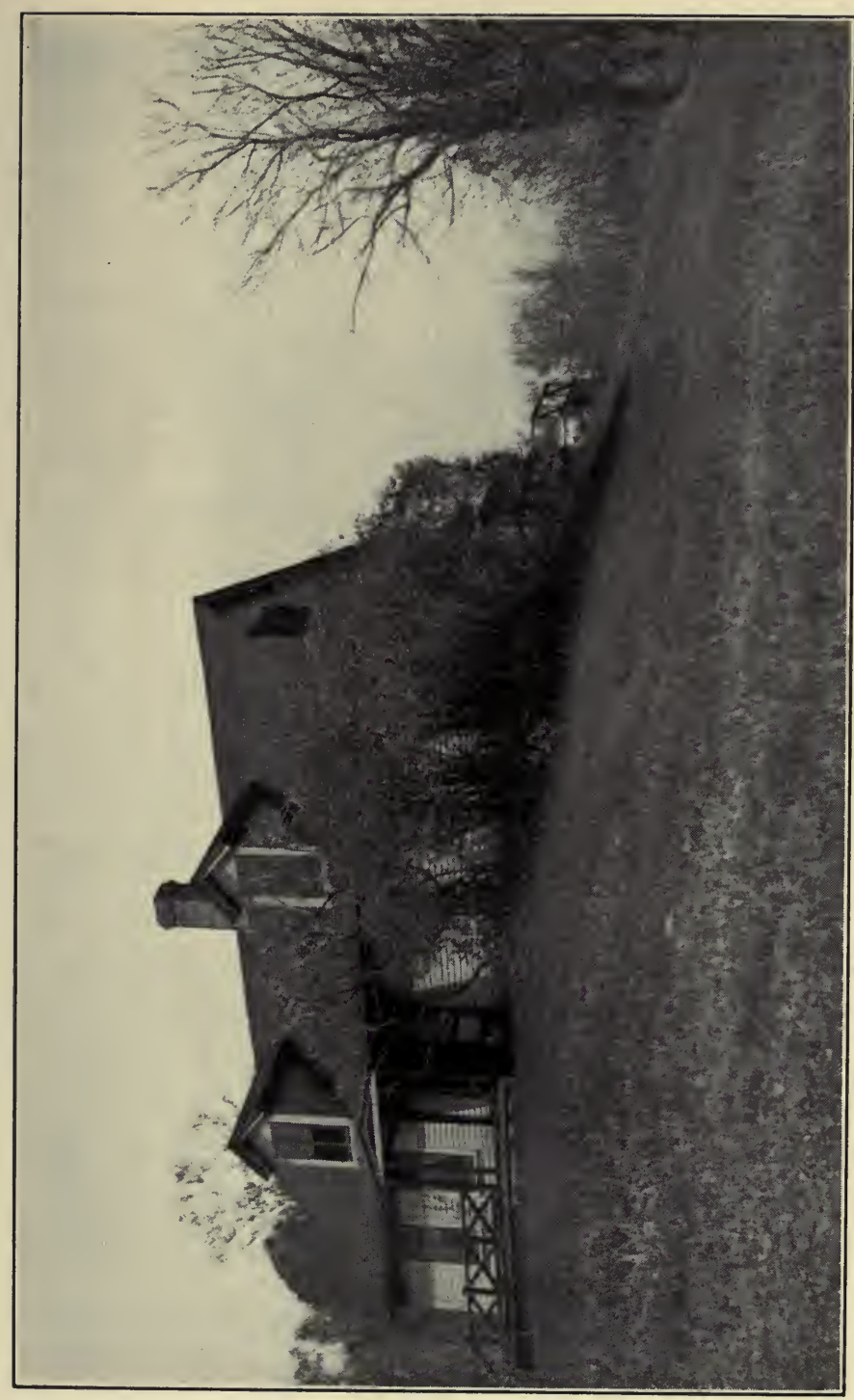

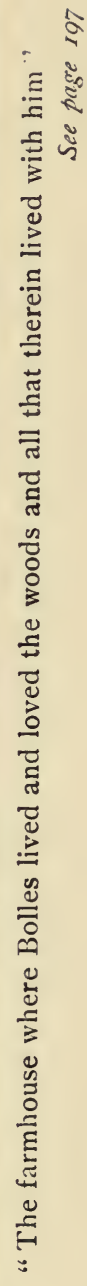



white-throated sparrow that sings all day about Chocorua. "Peabody bird" we call the whitethroat, from long custom, but to me his notes, clear, sweet and infinitely refreshing, seem to chant in accelerating diminuendo, "hap-pi-ness, hap-pi-ness, happiness," till I lose the quivering cadences in an infinity of distance where sight and sound blend in the passing of dear dreams. The white-throated sparrow comes to the hills with the pink buds of the trailing arbutus, whose blooms are nowhere else so white and fair, and something of their fragrance seems always to come from his song. In little nooks where the early spring sunlight wells in pools of golden warmth the perfumes of the arbutus blooms and of the white-throat's song come first, and they linger long into the summer where cool Northern hillsides hold the spring in their shadows. Sometimes the autumn, too, gives us a rare reblooming of the arbutus, and the white-throat sings his song of pure contentment well into the mellow haze of late September.

Now that May is in the mountains one may see the warblers budding from the twigs with the 
leaves, nor shall he at first know which dappling of living light has burgeoned from the wood or which flashed in from the sky above, so harmonious are the contrasts of rich color. Often it seems to be the leaves that sing, so well does the tiny songster fit upon his perch. All about the lake in beech and birch the young buds lisp and the half-open leaves trill with the tiny music of the parulas. As you pass from ridge to lowland and on to ridge again they lead you along the hillsides and on to the cool depths of remoter ranges where the ancient hemlocks still grow, their gray beards of usnea moss hanging sedately in the shadows among their dark trunks. The parulas feed and sing in the light of deciduous trees, but they nest in this moss in the shadows of the black growth. Here comes true the fairy tale of the birds that built their nests in beards, for as I rest in the cloistered seclusion of the hemlocks two parulas come and press aside the gray lace draperies of pendent moss and enter in. There is the beginning of the nest, this tiny cavern which they wedge with their bodies from the matted moss. The lower ends of this are to be turned 
up and interwoven, making the bottom more secure, and pendent there in her swinging cradle, safe from the eyes of owl or jay above, from fourfooted prowlers below, the mother bird will brood her rufous-wreathed white eggs.

Many another warbler will lead the May visitor to Chocorua through these lakeside woodlands which Bolles loved. Some toll him cheerfully from one low thicket to another, where he may see the bird and the wood violet in the same glance or pluck painted and purple trilliums and not lose sight of his quest. Of these is the black-masked Maryland yellowthroat, whose song of " witchery, witchery, witchery," always speaks for itself alone. No bird seems necessary for the production of this. It buds from the air as young leaves do from the twigs, impelled by a magic power within itself, nor, when you finally find the bird, demurely winding his masked way through the low growth, does the voice by any chance proceed from his throat. All warblers are ventriloquists, but I always think the Maryland yellowthroat of the Chocorua thickets the most demure magician of them all. Perhaps the black mask has some- 
thing to do with it, lending to the eye the same thought which the puzzled ear conveys. The yellowthroats are building now, weaving their grass nests in tussocks of swamp grass down by the water's edge, hiding them not so uniquely. indeed as the parulas, but almost as well. The spikes of swamp grass grow tall about each nest, and its deep cup if seen at all from the outside is to the eye but a tangle of the last year's grasses, matted down under this year's growth. If I find these nests it is only by looking directly down into the heart of each tussock until I reach the right one. Yet this is not particularly difficult. It means only a little patience in inspection, after the probable neighborhood has been defined by the presence of the birds themselves. The yellowthroats are shy about their nests. If you inspect them too often they will leave them and begin all over again in a new locality. But, away from the nest, they are an easy bird to see much of. A man in their neighborhood is an object of insatiable curiosity to them, and you do not need to discover them if they are near. Instead they will come, creeping and peering through the bushes, 
to inspect you if you will but sit quietly in the region in which that "witchery" song is born out of the circumambient air.

Into the upper end of Chocorua Lake flows a brook of transparent water, fed by melting snows, out of "the heart of the mountain." Along this the song of the water thrush leads the wanderer from one limpid pool to another, a song that has in it some of the liquid prattle of the stream but more of a dominant, aggressive note that carries far. There is a touch of sunlight in the color of the water thrush's breast, sunlight flecked with little brown shadow markings that are like the uniform brown of his back, and if it were not that he sticks so closely to the water he might suggest the oven-bird to the careless glance. There is something of the song sparrow and the oven-bird at once in his song. It is as if the two birds had mated to produce him and the singing masters of both families had had the youngsters to singing school. Up this clear-water brook the oven-birds call you by way of the height of land, the water thrushes from pool to pool, while the sun drops behind Paugus in mid afternoon, and the blue 
shadows of the Sandwich range add to the cool gloom which wells upward from the deep gorge which is the heart of the mountains.

On the way, as the water thrushes and Maryland yellowthroats sing from the thickets near the water, so the oven-bird sends his aggressive staccato from the middle distances of the higher trees. I never knew an oven-bird to sing from either a tree top or a low thicket. Always he sits on a limb well up the trunk yet well beneath the shade also, and sends forth that aggressive, eager call for knowledge. "Teach us, teach us, teach us," he cries to the wood gods, nor is he ever satisfied with his schooling, but applies persistently for more. The oven-bird is the very voice of the spirit of modern learning, crying always, in the wilderness of knowledge attained, for more knowledge. The wood gods have taught him much. Invisibility for himself he has almost learned. $\mathrm{He}$ sits like a knot on a speckled brown limb, and his speckled brown breast is so much like it that he may sing long there within a little distance of your eye before you see him. Invisibility for his nest he and his demure brown wife have learned 
completely. You may sit on it to rest among the brown leaves in the wood and not know it is there unless the frightened escape of the brown mother birds gives you a hint, and even then it is invisible, so completely is it hidden in the debris dropped by the previous autumn. Of dead weed stalks, grasses and brown leaves it is not only built but roofed, and with an entrance on one side that to the uninitiated might be an entrance to the nest of a field mouse, indeed, but never that to a bird's nest. It is not for greater knowledge of nest hiding that the oven-bird need pray to the wood gods, nor may we know what further wisdom he seeks, but all summer long he asks for it in no uncertain tones.

Out of the very treetops while the oven-bird shouts his prayer below comes the voice of the red-eyed vireo, uttering moral platitudes from dawn till dusk. It is no wonder that some birds go wrong with this monotonous preacher steadily droning out, "Don't do this; don't do that," to them all day long. The bluejays, who have robber baron blood stirring always under their gaudy military coats, jeer at this prating of platitudes 
and descend upon the vireo's hanging nest and eat the eggs from it, I always think, with more gusto than in their other freebooting, and small blame to them. The red-eyed vireo leads an exemplary life, no doubt, living properly on small insects and keeping up perpetual prayer-meeting, but his self-righteous twaddle must be intensely irritating to all but impeccably good birds that have to listen to it. In gladsome relief from this was the demeanor of the Canadian warblers, also flitting daintily in the treetops. I know the authorities say that the Canadian warbler frequents low thickets, but there is no mistaking the bird with his breast and throat of clear yellow and his necklace of jet beads, and this May the leafy topmost twigs of the deciduous trees in the Chocorua region held many such. They sang their liquid warble which has in it more than a suggestion of the song-sparrow notes of the waterthrush song, and they dashed out into the free air for insects which they captured, flycatcher fashion, and then dashed back again. The Canadian warblers are migrating, feeding and singing as they go on to their nesting sites farther north, and 
this year their favorite food must have been hanging high, for they were up there after it.

With the Canadians was the first wave of the tide of blackpolls which sweeps over the mountains, also bound north, in late May. More restless were these, constantly flitting and seeking food among the leaves, now in deciduous growth, again in the evergreens, ever moving on and ever singing their high-pitched, hissing whistle which is not so very different from the song of the black and white creeper, though a little more deliberate in movement and having a more staccato quality. So far as coloration goes one might mistake the male blackpoll for the black and white creeper were not the movements of the birds so distinctly different and the song as wiry but as soothingly crepitant as that of the cicada.

Night falls early in the deep heart of Chocorua, and full and clear the wood thrushes were yodeling of peace, one to another in the shadows, as I turned to descend. In the worn fields of the ancient clearing about the farmhouse where Bolles lived and loved the woods and all that therein lived with him, the song sparrows were trilling 
evening songs and the swifts twittering and circling nearer and nearer the big chimney which is their summer home. The bird cherry trees were white angels of bloom, and from all the land far and near the incense of opening blossoms made the air sweet and rose toward the high, mysterious altar of Chocorua's peak as if in adoration of the rose glow of its sunset tints. Chocorua Lake was a mirror in which the glory of the summit, the blue dusk of the lower ranges and its own shores were reflected in perfect beauty. It was a sounding-board as well, across whose level came to the ear innumerable bird songs, singing carols of praise to the passing of day. Out of the blue depths of the sky the cool of night dropped like a blessing from heaven and seemed to soften and liquefy all melodies into purer, more mellow music. Wood thrushes and hermits sang in the shadows hymns of praise to the most high peak of the mountain, a pantheistic worship that was old ages before any spires other than those of the spruces had pointed the way to heaven.

From the hillocks of the pasture to the topmost boughs of the forest all bird life joined in the 


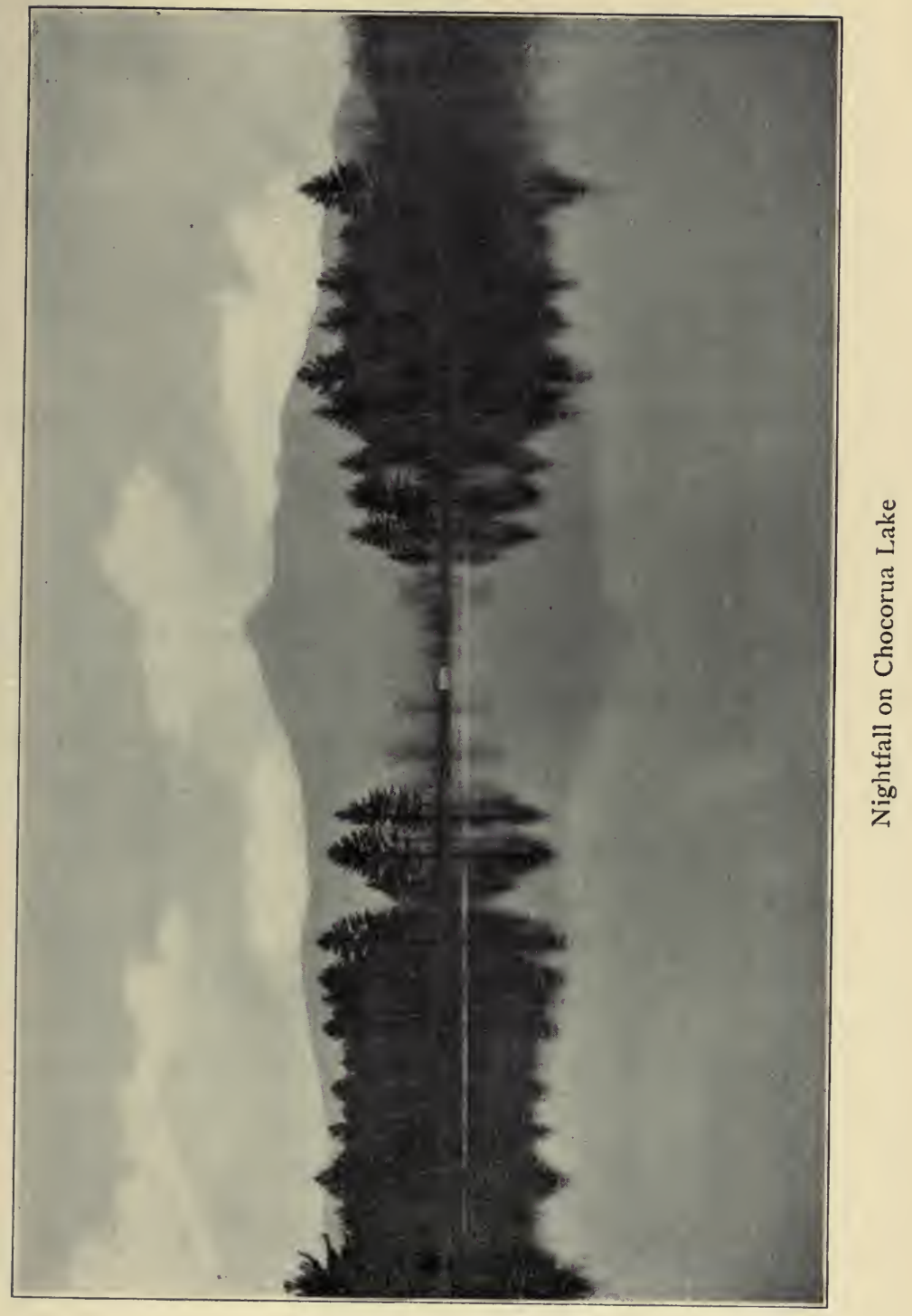



worship, making the welkin ring with praise of the pure joy of life, a chorus that quivered into silence only with the passing of the rose of mystery from the very tip of the high horn of Chocorua. Nor did the silence last long. Before the last wood thrush had finished his "Good night; all 's well; God is good," other songs of praise and the joy of life were echoing from swamp and wood and lake margin. Where the birds had ceased a myriad other voices took up new refrains. The dreamy trill of the tree frogs sounds from the perfumed dusk, a lullaby of the world primeval that sang the first man to sleep in some safe refuge in the deep woods. From the distant marsh the mingled voices of innumerable hylas ring a chorus of fairy sleighbells that rises and falls as the wind of evening drifts by. Nowhere in the world, I believe, can one hear such hyla choruses as he gets in May evenings from marshy pools among the New Hampshire hills. Coming from a distance the hypnotic insistence of the sound has a soothing, sleepy quality that lulls to rest. To seek its source and stand by the very border of the pool is to find it a frightful up- 
roar that shrills in the ears and rings through the head till the deafened hearer is driven to the upland again.

On the lake margin in the failing light it came to me as a sleepy drone of tiny bells, as if goblin sleighing parties were coursing gayly in the night on the white May snow of petals beneath the bird cherry trees. It and the dreamy trilling of the tree frogs were but a background for the voices of night birds that sounded now that those of the day birds had passed. High in air floated the nasal "peent, peent," of whirling nighthawks. Out of the velvet dusk across the glimmering water I heard a bittern working his old-fashioned pump, wheezily. "Cahugunkagunk, cahugunkagunk," he burbled, the weirdest bird voice of any that comes from marsh or mountain, yet in the peacefulness of the place sounding neither lonely nor uncouth. I fancy him, too, with his long beak pointed to the heights, worshiping the mountain peak in his own tongue. Whip-poorwills mourned gently one to another across the water as a token that the night had really come and the last glow faded from the lone summit now 


\section{BIRDS OF CHOCORUA}

so immeasurably withdrawn into the sky among the stars.

A yellow-billed cuckoo called from the thicket, then, indignant at receiving no answer, sprung his rattle and waited. Roused out of his first slumber a white-throat gave a faint "tseep" of surprise, then trembled into music for a moment and went to sleep again. "Hap-pi-ness, happi-ness, happiness," he sang, the notes slipping away into infinite distance and blending with the perfect quiet of the night and the sky. It was the very spirit of the place speaking and reminding me again of the gentle writer who sang so clearly of the peace and beauty of the Chocorua woods and who now sleeps, after singing. 



\section{INDEX}

A

Achilles, 156, 157

Adam, II 7

Alcott, 99, 100, 102

- Louisa, IOI

Alder, white, 68

Aldrich, Thomas Bailey, 30

Allen, Ethan, I7I

Amesbury, 129

Anemone nemorosa, 143

Angle-wing, 56

Antietam, I93

Apple, Baldwin, 6

- russet, II 5

- wild, 127

Appledore, 44, 46, 48, 49, 50, 52, 56,59

Arbutus, trailing, 94, I38, I40, I4I, 142, 146, 199

Arcady, 37

Argynnis, 67

- cybele, 39

Asclepias cornuti, 37

- tuberosa, 38

Assabet, IOI

Asters, 37, 49, 86, I07, II3

Astraea, I 50

Atlantis, 45

Azalia, 9

B

Babylonian kings, 187

Bayberry, 9, 25, 46, 52, 81, 88

Bee, bumble, 25, 4I

- honey, 57

Beech, 21, I77, 280

"Bemis Place, the," 35
Bilboa, I 19

Billington, I39

- sea, I39

Birch, 27, 69, I 28, 200

- black, 2

- white, 2 I

- yellow, 27, I7I

Birds

Bittern, 2 ro

Blackbird, 32, 36, I40

Blackpoll, 207

Bluebird, 169

"Bob white," I3

Cedar waxwing, 127

Chewink, 23

Creeper, black and white, 207

Crow, I 26

Cuckoo, yellow-billed, I98, 2 I I

Duck, 63

Finch, purple, 194

Flycatcher, great-crested, I4

- olive-sided, 55

Grosbeak, I94

Gull, 56

- herring, I 29, I30

Hawk, fish, I3I

- night, 2 I0

Heron, great blue, 57

- little green, $7 \mathrm{I}$

Jay, I26, 200

- blue, 205

Kingbird, 56

Kingfisher, 70, 7 I

Maryland yellow-throat, 52, 201, 202, 204

Mourning Dove, I3 
Nuthatch, white-breasted, I $7 \mathrm{I}$

Oven-bird, 203, 204, 205

Owl, 200

"Peabody bird," I99

Quail, I3

Robin, 2, 3, 55, I27, I39, I93, I 94

Sandpipers, 56, 70

Skylark, 2

Snipe, Wilson's, $x_{3}$ I

Sparrow, song, 52, 55, 140, 169, 203,206

- white-throated, I99, 2 II

Swallow, 7

- barn, $5,6,53$

- tree, 53,54

Tanager, 194

Thrush, I93, I94

- hermit, 208

- water, 203

- wood, I95, 196, 208

Vireo, 2I

- red eyed, 205, 206

- warbling, I94

Warblers, 194, 199

- Canadian, 206, 207

- parula, 200, 202

- wood, 86

Whip-poor-will, 197, 2 10

Black Mount, 2, 3, 4, 13

Blackberries, 47, 8I

"Blobs," I42

Blueberries, 4, 8I

- low-bush blacks, 4

- pale blue, 4

Blue flag, 22, 47

Blue Hill, 32, 33

Bluets, 152

Bolles, Frank, 197, 200, 207, 208

Boston Light, 76

Bouncing Bet, 89

Bradford, William, 75, 76, 105, I37, $\mathrm{I}_{3} 8, \mathrm{I}_{39}, \mathrm{I} 46, \mathrm{I} 47$

Bulkeley, Rev. Peter, 77

Burial Hill, 105, I37, I38, I39, I47
Buttercup, I46, 186

- bulbous, 153

Butterflies,

- Angle-wing, 56

Argynnis, 67

- cybele, 39

Baltimore, 4I

Cabbage, 56

Colias, 27

Colias philodice, 40

Fritillary, great spangled, 39

Grapta interrogationis, $\mathbf{x} 44$

Hesperiidae, 144

Hunters, 56, I44

Lycaena pseudargiolus, I44

Monarch, 39, 56

Mourning cloak, 143,146

Papilio turnus, 38

Pyrameis huntera, 144

Sulphur, 40

Vanessa antiopa, I43

C

Cabbage butterfly, 56

Cadiz, I I9

Caltha palustris, $\mathrm{I}_{42}$

Camaguay, III

Cape Cod, 75, 145

Cape of Good Hope, 148

Caraway, 43

Cardamine praetensis, $\mathrm{I}_{42}$

Carrageen, 54

Cedar, II, I 27, I 28

Cedar berries, 127

Cedar, red, 9, 25, 37

Cedar wax wing, 127

Ceylon, 63 , I48

Charter Street, 148

Checkerberries, 140 , I4I

Chelone glabra, $4 \mathrm{I}$

Cherry-bird, 208, 210

Cherry, wild, 46, 50, 8I, 83

Chestnut, 68

"Cheviot Hills, The," 33 
Chewink, 23

Chicory, I

China Sea, 148

Chipmunks, I07

Chocorua, 3, 201, 206, 207, 208, 209

Chocorua, Lake, I97, 203, 208

- mountain, 197,208

- woods, I98, 2 II

Chokeberry, 50

Cicada, 207

Cineraria maritima, 84

Cinquefoil, $5 \mathrm{I}$

Civil war, $185, \mathrm{r} 86, \mathrm{I} 89$

Clark's Island, 135

Clematis, 47, 48, I07, II 3

Clethra, 62,66

Clover, white, 58

Colias, 27

- philodice, 40

Concord, 63, 65, 7I, 90, 91, 92, 96, $97,98,99$

- Bridge, 9I

Confederate, Igr

Convolvulus, III

Coreopsis, 44

Corydon, 37

Country brook, 26, 27, 28

Cowslip, $\mathbf{I 4 2}^{2}$

Crabs, 55

Cranberry, 5I

Cranberry bog, I2, I40

Cranesbill, 47

Creeper, black and white, 207

Cress, bitter, $\mathbf{I 4}^{2}$

Crow, $\mathbf{2} 26$

Cruciferae, 56

Cuckoo, yellow-billed, 198, 2 II

Custom House, 150

D

Daisy, 186

- ox-eye, 23

Dandelions, 5I, I52
Dandelions, fall, Iog

Deerfield River, 164, I8r

Derby, Elias, 150, I 58, r 59

Derby Street, $\mathbf{x} 48$

Dexter, "Lord" Timothy I 24

Dickens, I 23

Dreadnaught, I 20

Duck, 63

Dummerston, I77

Dunkirk, II9

Dusty-miller, 84

\section{E}

Elder, 46,50

Emerson, 90, 97, 99, 100, 102

Eos, 6I

Epigaea, 140, I4I

Eric the Red, 143

Essex Institute, 150, I6I

Eve, 52

Everlasting, 192

\section{F}

Ferns

Cinnamon, 22, 109

Hay-scented, 22

Interrupted, 22

Lady, 22

Maiden-hair $1: 95$

Royal, 22, ro9

Finch, purple, I94

Firefly, 3 I

Florida Keys, 145

Flycatcher, great-crested, 14

- olive-sided, 55

"Flying Dutchman, The," I20, I48

Forget-me-not, 22

Fox, 107

Fragaria, I53

Free Press, 123

Fritillary, great-spangled, 39

Frog, tree, 209 
G

Gallows Hill, 149, I5 I, I 53

Garrison, William Lloyd, 123

Gaultheria, I4I

Genista, 154

Geraniums, red, 44, 58, 59

Gerardia, 68

- flava, $4 \mathrm{I}$

- golden, 40, $4 \mathrm{I}$

- tenuifolia, 67

Gettysburg, I93

Ghettos, I 50

Goldenrod, 27, 49, 86, 107

- sea-side, I28, I30

Gosnold, 76

Grand Army, 186

Grand Turk, The, I50, 158, 159

Granite, 49

Grant, I95

Grape, fox, III

Grapta, interrogationis, I44

Gratiola aurea, 70

Greenbrier, 8, 8I, III

Greenbush, 106

Green Harbor, 2, 3, 7, 10, 12

Grimes, C. S., I65, I73, I78

Grosbeak, I94

Guadaloupe, II9

Gulf Stream, 64

Gulistan, I88

Gull, 56

- herring, I 29, I3C

Gurnet, I36, I45, I47

H

Habenaria fimbriata, 36

- psycodes, 35,38

Hardhack, 153

Harold, 94

Harraden, Jonathan, I56, I57

Hastings, 94

Hathorn, Judge, I 50

Hawk, fish, I3I
Hawk, night, 2 10

Hawthorn, 142

Hawthorne, Nathaniel, 98, 102, $149,150,151,160,162$

Haystack mountain, I64, 165, 172, 182

Hedge-hyssop, 68, 70

Hemlock, 16, 21, I72, 20 r

Hepatica, 95

Heron, great-blue, 57

- little green, $7 \mathbf{I}$

Herring, I 28, I30

Hesperiidae, 144

Hildreth, Richard, I24

Holly berries, 127

Hollyhock, I9

"Home Sweet Home," II7

Homer, 138

Hoosac Tunnel, I8r

Huckleberry, 4, 50, 88, I 28

- low-bush, black, 46

Hunter's butterfly, 56, r44

Hyla, 52, 209

\section{I}

Immortelles, 192

Indians, 32, 85

Indian pipe, 42

Ireland, II 9

Isles of Shoals, 44, 49

Ivy, I07

- poison, rro

\section{J}

Jamshid, 188

Jay, I 26, 200

- blue, 205

Jewel Weed, 22

Job's Hill, 23, 24

Jones, Paul, I55

Joppa, I 25

- flats, 122

Juniper, 25, 69 
K

Kathan farm, 177

Kelp, 55, 57

Kenoza lake, 24

Khan, Genghis, 188

Kingbird, 56

Kingfisher, 69, 70, $7 \mathrm{I}$

L

Ladies' Tresses, 86

Launcelot, I44

"Legend of Ara-coeli," 34

Lichen, 9, 108, 184, 185

- reindeer, 10

Lilac, $17,29,186,187,188,189$

Liliputian, 85

Lily, pond, 32,42

- water, 82

Lincoln, 63

Liverpool packet, I20

London pride, 19

Long Point, 75, 76, 77

Lotos, IOI

Love-in-a-mist, 44

Lycaena pseudargiolus, I44

\section{M}

Madeira, II9

Magnolia, I62

Maidenhair fern, 95

Manomet, 136, 143, 145, 147

- head, I35

- heights, 146

Maple, 2I, 68, I28, I40, I64, I65, I7I

- sap, I79

- sugar, I64, I7I, I80, I82

Marigold, 44

- marsh, 142

Marjoram, rg,

Marshfield, I, 3, 6, 14

Maryland yellow-throat, 52, 20r, 202, 204
Massachusetts bay, I05

Mayflower, the, I0, 76, 94, 95, I05, $135,136,142,147$

Mayflower, I39, I4I, I42, I43, I 46,147

Meadow Sweet, 67

Memorial Day, I84, I85, I86, I87, I90, I9I, I92, I95

Merrimac, $15,20,27:$

Miantowonah, 32, 42

Mica, 49

Milkweed, 37, 39, 40, 4I

Mint, wild, 20

Minute Man, 91, 92, 93, 99

Mirror, New York, I05

Mogg Megone, I6

Monarch butterfly, 39, 56

Monotropa uniflora, 42

Morning glory, 49

Mourning cloak butterfly, I43, 146

Mourning dove, 13

Mussels, 54

\section{$\mathrm{N}$}

Naples, 145

Naples, bay of, 145

Newbury, II 8

Newburyport, I18, II9, I2I, I23, 125,129

Nuthatch, white-breasted, I7I

\section{0}

Oak, 68 , 140

Oak, red, 2I, 99

- white, 2 I

Octavia, Miss, $\mathbf{I}^{2} 2$

Odysseus, I60

Odyssy, I6o

Old Curiosity Shop, 123

"Old Oaken Bucket, The," I04, II4, II 7

Omar, I88 
Orchid, 38

- larger, fringed, 36

- small purple-fringed, 36

Oriole, 162

Oven-bird, 203, 204, 205

Owl, 200

\section{$\mathbf{P}$}

Papilio turnus, 38

Parsnip, wild, 49

Parula, 200, 202

Paugus, 203

Peabody, 150

Peabody Academy of Science, I6I

"Peabody Bird," I99

Peabody, Joseph, 158

Peaked Hill bar, 87

Peregrine, 3

Persepolis, 187

Persia, 187,188

"Pickles for the Knowing Ones," 123

Pierpont, John, 123, 124, 132

Pilgrim, 37, 75, 77, 82, 87, 89, 105, I37, I42, I44, I46, I47

- cemetery, 3, 6, 12

- children, I, I4I

- descendants, 3

- mothers, 78

- scouts, 80

- shrines, 78

- warriors, $8 \mathrm{r}$

Pine, 16, 21, 68, 129, I9I

- pitch, 85

Pink, 44

- clove, 34

Pipsissewa, 42

Plantain, $5 \mathrm{I}$

Plum, beach, $8 \mathrm{I}, 88, \mathrm{r} 28$

Plum Island, 132,133

Plymouth, 2, 94, I35, 138, 142, I 43

- bay, Io, 145

- colony, 105, 137
Plymouth rock, 105

Ponkapoag, 31, 33, 34, 35

- brook, 35

- pond, 31, 32, 42

Poplar, silver-leafed, 88

Poppies, 19, 44, 58

- shirley, 49

Port au Prince, II9

Port Hudson, 193

Potentilla, I52, I53

Provincetown, $7677,80,87,136$

"Prynne, Hester," I60

Puritan, 89, I54

Pyrameis huntera, I44

Pyrola, 42, 140

Quail, I3

Quartz, 49

Queenstown, I20

$\mathbf{R}$

Race Point, 75, 76, 78, 80

Rajah (ship), 150

Raspberry, 46

Revolution, the, 186,189

Robin, 2, 3, 55, I27, I39, 193, 194

Rock weed, 53, 54, 57

Rose, damask, 34

- wild, 9, II, 24, 25, 26, 50, 58, $8 \mathrm{I}, \mathrm{II} 3, \mathrm{I} 87$

Royal Society, philosophical transactions of, $\mathrm{x} 66$

Rubaiyat, $\mathrm{I} 88$

Rudbeckias, 23

Rush, bog, 5 I

\section{S}

Sadi, 188

Sagittaria, 36

Sahara, 82

Salem, 148, 149, 150, 152, 154, 
I55, I56, I57, I58, I6r, I62, $x 66$

Sandpipers, 56,70

Sandwich Range, 204

Sandy Hook, 120

Sassafras, 9, 69

Saxifraga virginiensis, 143

Saxifrage, 43, I9I, I92

Scarlet Letter, I22, I49, I6r

Senegambia, 148

Shadbush, $46,5 \circ$

Sinbad the Sailor, $\mathrm{I}_{3} 6$

Skylark, 2

Sleepy Hollow, 99

Smelt, I28, I30

Smilacina, $186,189,190,192$

Smilax, III, I90

- rotundifolia, $8 \mathrm{I}$

— wild, 8 r

Smith, Capt. John, 33, 76

Snake, green, 52

Snipe, Wilson's, r4r

Sparrow, song, 52, 55, x40, 169, 203, 206

- white throated, 199, 2 II

Spiranthes, gracilis, 86

Spofford, Harriet Prescott, I24, I 29

Spruce, $x 72$

Standish, Myles, 78, 85, 89

Steeplebush, 24, 25

Stevenson, I6r

St. John's-wort, 47,58

St. Martins, I I9

Strawberry, 4

- wild, 152

Sudbury, ror

Sumac, 9, 27, 50, 58

- staghorn, 8, 26, 46

Surinam, II9, I48

Swallow, 7

- barn, 5, 6, 53

- tree, 53,54

Sweet-fern, 25, 8I

Sweet william, $\mathrm{r} 9$
$\mathbf{T}$

Tambourine bird, 23

Tamerlane, 188

Tanager, 194

Thaxter, Celia, 49

- -, garden of, 44,58

- , grave of, 58

Third Cliff, II 2

Thistle, 25

Thoreau, 60, 65, 66, 67, 69, 73, 74, $98,99,100$

Thoroughwort, 67,68

Thrush, r93, I94

- water, 203

- wood, r95, 196, 208

Toadflax, 47

"Tocsin, the," 133

Town Brook, 138

Trillium, painted, $20 \mathrm{I}$

- purple, 201

Troy, 97, 138

Truro, 86

- North, 77, 78, 79, 85

Turtle-head, 4I

\section{U}

Ulysses, I60

Usnea moss, 200

\section{V}

Vanessa antiopa, I43

Violet, $153,186,190, r_{92}$

- wood, 201

Vireo, 2 I

- red-eyed, 205, 206

- warbling, rgr

Virginia creeper, 47

Vishnu, 96

\section{W}

Walden, $60,62,65,66,68,69,70$, $7 I$ 
Wapping Old Stairs, 122

Warbler, I94

- Canadian, 206

- wood, 86

Warsaw, 150

Water plantain, 37

Water striders, 2 I

Webster, Daniel, 2, 3, 6, I 2

- farm, 3

- path, ro

- place, 4

- well house, 7

West, Ebenezer, ${ }_{5} 8$

Whin, I54

Whip-poor-will, 197, 2 ro

White Mountains, 45

White, Peregrine, $1,3,6$, I 2

- - mother of, ro

Whitefield, 123

Whittier, I7, 20, 23, 24, 28, I 23
Whittier birthplace, I8

- fireplace, I5

Whittier's mother, I6

"Wild boat of the Atlantic, the," I 20

Willow, 88, I40

Wilmington, 164,175

Wind flower, 143

Winslow, 12

Witch Hazel, I 13

Woad-waxen, 154

Woodbine, I07, I I0, II I

Woodchuck, 12, I07

Woodworth, Samuel, I04, I06, I I0, II 4 , II 5

$\mathbf{Y}$

Yarrow, 25, 47, 48, 49 





\section{PLEASE DO NOT REMOVE \\ CARDS OR SLIPS FROM THIS POCKET \\ UNIVERSITY OF TORONTO LIBRARY}

Biollad 
